\title{
"VINCULOS, RELACIONES Y REPRESENTACIONES SOCIALES DESARROLLADAS ENTRE PADRES A TRAVÉS DE LA PRÁCTICA DEL FÚTBOL"
}

\author{
Licenciado HECTOR COLOMBO
}

Tesis para optar por el grado de Magíster en Deporte

Director: Dr. Eduardo Galak (CONICET-UNLP)

La Plata, Agosto de 2015 


\section{Dedicatorias}

A todos los que participan del Torneo de Fútbol para padres Virgen Niña a lo largo de estos años, que saben brindar lo mejor de sí, para transformarnos en mejores personas.

En especial a vos, Gerardo, el amigo de todos los equipos, que nos dejaste para ir a jugar a otras canchas, otros cielos, pero seguro, para hacer nuevos amigos.

A mi familia, el impulso de toda mi vida. 


\section{Agradecimientos}

A los Docentes de la Maestría en Deportes de la Universidad Nacional de La Plata, por su sabiduría, conocimiento y generosidad para compartirlo.

A los Profesores Marcelo Giles y Ricardo Crisorio, Directores de los Posgrados de Maestría en Deporte y Maestría en Educación Corporal, por seguir apostando por la excelencia en la formación de docentes e investigadores de la Educación Física en la Argentina.

A mi docente tutor y director de tesis, Dr. Eduardo Galak, por su paciencia, dedicación, rigurosidad y por sobre todo por acompañarme y ayudarme a sacar de mi cabeza y poner en palabras lo que quise decir de esta investigación.

A la Fundación Lúminis, que becó mis estudios y me dio la oportunidad de volver a sentirme un alumno, al Ministerio de Educación de la Nación que a través del programa PROFITE, facilitó e impulsó la culminación de este proceso.

A todos los padres que forman parte de esta experiencia y que colaboraron con las encuestas, entrevistas, fotos, videos y anécdotas para el desarrollo de ésta investigación.

Agradezco a mi familia, a mis hijos a quienes les robe tiempo y espacio y me devolvieron su ayuda y sabiduría en el uso de tecnologías; a mi mujer, que corrigió textos y puso mucho más que palabras en este tiempo, ellos supieron apoyarme en esta aventura de volver a estudiar.

A todos, los que de alguna u otra manera, colaboraron, estimularon, enriquecieron este proceso, a todos, les estaré siempre muy agradecido. 


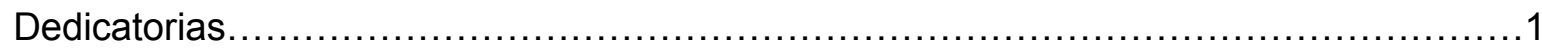

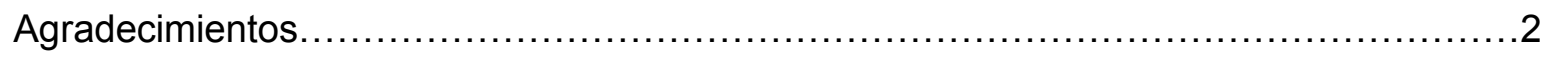

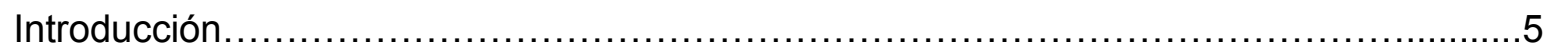

Capítulo I - Conceptualizaciones y categorías

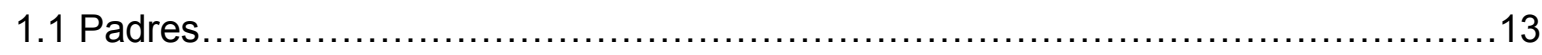

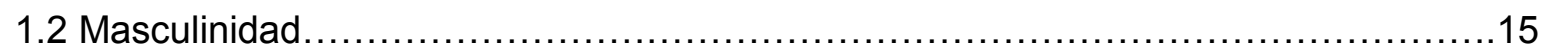

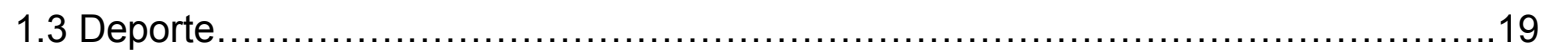

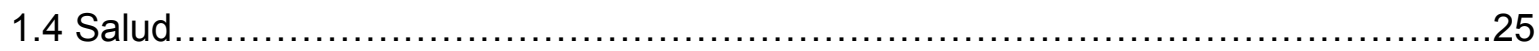

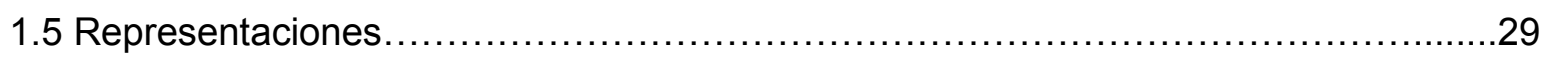

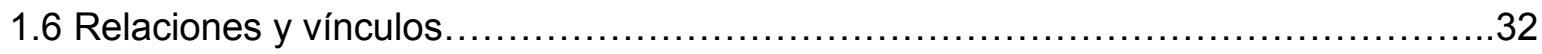

Capítulo 2 - El trabajo de campo. Los datos

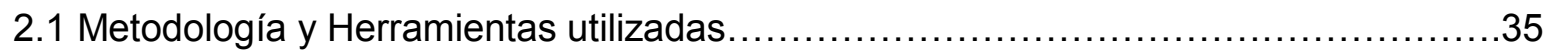

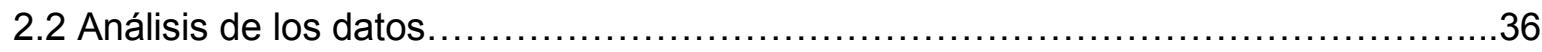

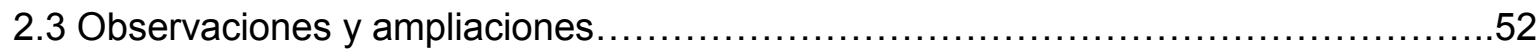

Capítulo 3 - El análisis de los hechos y los textos

3.1 Los padres y el Torneo de Fútbol. Razones para juntarnos.........................55

3.2 El fútbol en el Torneo de Padres. La elección de la práctica deportiva.................66

3.3 La Salud en el Torneo de Fútbol para padres. ¿El Fútbol es una buena alternativa?..73

3.4 Como operan las representaciones en la práctica deportiva del fútbol de padres.....79

3.5 Como se desarrollan las relaciones entre los sujetos participantes..................82

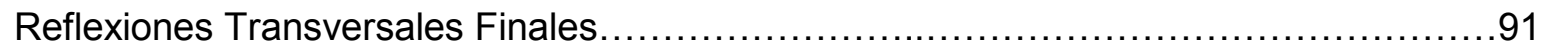

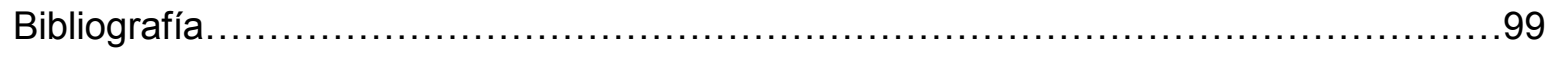

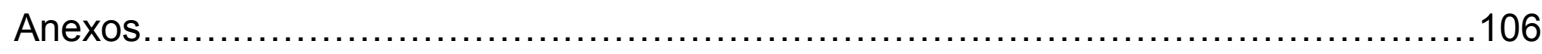




\section{"VINCULOS, RELACIONES Y REPRESENTACIONES SOCIALES DESARROLLADAS ENTRE PADRES A TRAVÉS DE LA PRÁCTICA DEL FÚTBOL"}

Por práctica entenderemos cualquier forma coherente y compleja de actividad humana cooperativa, establecida socialmente mediante la cual se realizan los bienes inherentes a la misma mientras se intentan lograr los modelos de excelencia que le son apropiados a esa forma de actividad y la definen parcialmente, con el resultado de que la capacidad humana de lograr la excelencia y los conceptos humanos de los fines y bienes que conlleva se extienden sistemáticamente.

(Mac Intyre, 1987: 248)

\section{INTRODUCCION}

Este trabajo pretende explorar las vinculaciones, relaciones y representaciones que se producen en un grupo de padres que sistemáticamente se reúnen para la práctica deportiva del fútbol, a través de su participación en un Torneo de Fútbol destinado a padres de alumnos que asisten a Colegios de la zona de Bella Vista, localidad del partido de San Miguel y otros partidos aledaños, en la provincia de Buenos Aires. Es decir, los jugadores que participan del Torneo deben tener hijos escolarizados en el Colegio al cual representan.

Resulta importante comenzar por una serie de confesiones epistemo-metodológicas: la principal motivación a encarar este estudio es la de ser un participante más del Torneo. En efecto, soy parte de esta práctica desde sus inicios y siento que hay algo importante para decir sobre esta práctica.

Para quienes hemos sido formados en el campo disciplinar de la Educación Física desde una perspectiva biologicista, enciclopedista, reproductivista, y donde el objeto de estudio fue siempre externo y el posicionamiento del investigador debía ser siempre objetivo y alejado; la idea de realizar una indagación en un campo donde estamos involucrados como protagonistas, nos parece, a primera vista, un desafío un tanto difícil. Adentrarme en un proceso de investigación de este tipo, puso en juego una serie de discusiones (conmigo mismo y con otros colegas) que ya vengo teniendo desde hace 
algún tiempo en relación al desarrollo de mi profesión. Desde hace más de veinte años me desempeño en Instituciones de Formación Docente en Educación Física y he podido correrme de ciertos paradigmas de formación y bucear y experimentar en otras formas, métodos y prácticas de enseñanza, de ver y de vivir la Educación Física como producto de una constante actualización y perfeccionamiento, participación en Jornadas Académicas, Congresos y por supuesto, el trato e intercambio permanente con colegas, alumnos y practicantes.

Retomo el concepto de vivir la Educación Física porque, además de dedicarme plenamente a esta profesión docente, siento que a través de la participación en el Torneo de Fútbol para Padres recuperé una instancia de acción y protagonismo en las prácticas deportivas de manera plena y activa como hacía mucho tiempo no lo había podido lograr. Cuando me refiero de esta manera a esta experiencia quiero decir que supera ampliamente el ocasional encuentro entre amigos para jugar al fútbol, prenderse en el partido del potrero de la esquina, (en mi barrio todavía existen los potreros, por suerte) y jugar "para el equipo donde falte uno", aceptar la invitación esporádica para un partido de tenis, intentar por enésima vez "salir a correr" o empezar el gimnasio "para estar en forma".

Quienes hemos tenido la posibilidad de experimentar el desarrollo de la infancia y la juventud en el ámbito deportivo federado y amateur, jugar campeonatos, dar vueltas olímpicas, alzar la copa, disfrutar del triunfo y sufrir en la derrota, entrenar muchísimas horas a pesar de las inclemencias del tiempo, estar en un banco de suplentes y desvivirnos por entrar y dejar el alma en el campo de juego; atesoramos esas vivencias de manera muy especial porque han formado parte de nuestra vida y sin duda han operado en la constitución de la persona que somos.

Superada la etapa de formación profesional, titulación, inicio, desarrollo y especialización de la profesión, conformación de una familia, convertirme en padre con las responsabilidades y obligaciones (privilegios maravillosos también, sin duda, no los olvido!) y renunciamientos personales que ello representa, encuentro (encontramos, me animaría a decir, todos los padres que participamos del Torneo de Fútbol) un espacio único, propio, singular que nos reúne.

La recuperación del espacio deportivo en la edad adulta, supone en principio, una serie de requisitos y pormenores a tener en cuenta, directamente vinculados al sexo y 
género, edad, estado de condición física y salud, saberes y experiencias previas relacionadas con la práctica a realizar, que cada uno y en forma particular debe hacerse cargo al retomarla. Un aspecto tal vez menos tenido en cuenta, pero del que también hay que ocuparse, casi siempre luego de tomar la decisión de retomar la práctica deportiva, es con quién y dónde.

Creo de suma importancia realizar un análisis de esta experiencia dado que considero el desarrollo de las prácticas corporales, y entre ellas muy especialmente las prácticas deportivas en tanto fenómeno social y cultural de trascendencia de nuestro tiempo, constituye el objeto de estudio de la Educación Física. Entender e interpretar las mismas no solo sus dimensiones estructurales, reglamentarias, de competencia federativa y profesional, sino también los diferentes contextos, realidades sociales, usos y representaciones y sobre todo, los impactos relacionales que tienen entre los sujetos que las practican. Pensar el deporte en este contexto exige, entre otras dimensiones, reflexionar en su relación con la esfera lúdica, en la práctica deportiva entendida como juego o como competencia; o tal vez indagar en que es lo que se busca en el deporte cuando se lo elige como parte del uso del tiempo libre de las personas.

Pues bien, he aquí el escenario elegido para realizar mi Tesis de Maestría. Quiero indagar, describir, interpretar y tratar de explicar cuáles son los fenómenos y manifestaciones relacionales que se producen a través de esta particular práctica deportiva que congrega hoy más de 400 padres, todos los domingos por la mañana, en la localidad de Bella Vista.

Lo que distingue a una práctica de otras y a la misma práctica realizada en diferentes contextos, en parte, es la manera en que los conceptos de los bienes y fines relevantes a los que sirven las habilidades técnicas, las destrezas que se necesitan para realizarla, y aquellas formas y configuraciones relacionales entre los sujetos que la realizan, se transforman y enriquecen por esa capacidad de adaptabilidad, de flexibilidad, de acomodación de las personas; y en consideración a esos bienes internos que parcialmente caracterizan cada práctica, definen los modos en que estas ocurren. De esta manera, muchas personas que deseen realizar una determinada práctica, el fútbol, la 
práctica deportiva tratada en este caso de estudio, encuentran diferentes espacios y formas en la que esta puede desarrollarse, ajustada a sus posibilidades e intereses. Las prácticas nunca tienen objetivos estáticos, metas fijas permanentes en el tiempo, porque las mismas se transmutan, cambian, se modifican a través de la historia de la misma actividad, por lo tanto no es accidental que cada práctica tenga su propia historia (Mac Intyre, 2006). Comenzaré entonces, por describir brevemente el proceso de gestación, origen e historia de la organización de este Torneo de Fútbol para padres, de características muy singulares.

Los Torneos de Fútbol para Padres en la localidad de Bella Vista, comenzaron en el Colegio La Providencia en el año 2000. El primer propósito fue nuclear a los padres de la misma escuela para fortalecer la identidad institucional y el espíritu de familia según reza el propio lema de la Institución. Luego, a partir de relaciones externas a la escolaridad de sus hijos, empezaron a concretarse partidos de fútbol amistosos con padres de otros colegios de la zona. Así, fue generándose la idea de encontrarse regularmente los domingos por la mañana en la sede deportiva del Colegio y jugar partidos amistosos que se iban acordando domingo a domingo en forma casual y aleatoria con los equipos que frecuentaban el espacio.

Al constituirse varios equipos del mismo Colegio Providencia para un torneo interno y algunos colegios cercanos con representativos propios y con intenciones de relacionarse con cierta frecuencia, se ideó el primer Torneo Copa Providencia con un total de 8 equipos. El torneo fue todo un éxito y año tras año fue ganando adeptos y de esta manera precisó de una mayor cantidad de canchas, nuevas franjas horarias, establecer reglamentos propios y particulares, fijar edades y categorías, constitución de un tribunal de disciplina y el marco normativo necesario para su normal desarrollo.

A partir del año 2011 el Torneo mudó su sede y cuerpo organizativo ${ }^{1}$ pero mantuvo a la mayoría de los equipos protagonistas originarios y sumó nuevos equipos. En el año 2013 (al momento del presente trabajo) el torneo elevó el número de equipos a 24 con un

\footnotetext{
${ }^{1}$ El torneo de Colegio de la Providencia se convirtió inesperadamente en un torneo de futbol de 8 jugadores en el campo de juego por equipo; algunos especulan que por razones económicas: menos jugadores por equipos, más equipos, más canchas, más partidos, más recaudación... en una concepción mercantilista del deporte. Lo cierto es que la mayoría de los equipos participantes constituyó un nuevo torneo de fútbol 11 con 12 equipos que respetaban y querían continuar con la idea original; bajo la coordinación de un grupo de padres de diferentes colegios participantes. Al año siguiente comenzaron a emigrar los demás equipos que quedaban en el torneo del Colegio de la Providencia, y a incorporarse otros nuevos.
} 
promedio entre 15 y 18 participantes por equipo lo que supera una población de 400 padres que se reúnen cada domingo para la práctica deportiva del fútbol. El Torneo fue cambiando y reajustando su dinámica, reglas y adaptaciones constantemente, pero mantiene invariable su espíritu participativo, de competencia y confraternidad.

Siendo protagonista del mismo a partir de formar parte de uno de los equipos participantes del Torneo desde sus orígenes en la Copa Providencia, es que despierta mi interés en investigar los eventos que pretendo describir, interpretar; los procesos relacionales, vinculantes, simbólicos y significantes que suceden entre los padres (categoría fundamental en cuanto originalidad de unidad de análisis) que asisten y participan activamente de estos encuentros deportivos, objetivando en lo posible esa búsqueda general de identidades, de imágenes y símbolos en acciones, y actos más visibles y concretos como los que ocurren en cada jornada deportiva.

Para tal fin desarrollo un estudio de tipo descriptivo, con un enfoque interpretativo. A su vez, a partir de un diseño cualitativo realizo una interpretación sobre los hechos estudiados en su contexto, no necesariamente definitiva; dándole significación y relacionando los hechos y actores a modo de poder explicitar una realidad. Se trata de describir aquellas situaciones y causas que dan sentido y significado a este continuo y sistemático encuentro entre adultos en torno a la actividad deportiva elegida. El intento por encontrar relaciones entre las categorías y formular generalizaciones conceptuales define el criterio de alcance de las conclusiones, que pretende ampliar el campo de aplicación de la teoría sin desligarse de la base empírica de partida, esto es, válida para un universo acotado, sin pretender universalidad.

El formar parte de uno de los equipos iniciadores y fundadores del Torneo, me sitúa como una figura conocida por todos, lo cual facilita el proceso de indagación y admite un posicionamiento interpretativista del investigador. Mi carácter de investigador participante permite una mirada y una interpretación de los hechos, acontecimientos, sucesos y discursos subyacentes del campo estudiado. Este posicionamiento requiere de la interacción del investigador y el campo que investiga y de la reactividad y flexibilidad necesaria y deseable en este procedimiento, en busca de decir algo más, o algo nuevo de lo que aún no está dicho. En este sentido, el conocimiento y la vivencia de los hechos y el contexto (Guber, 2005) facilitan el abordaje a partir de las técnicas e instrumentos de recolección seleccionados. 
El trabajo combina las tareas de campo de encuestas, entrevistas, observaciones de campo y la propia vivencia como participante del evento; con el análisis de textos escritos en los diversos sentidos y perspectivas en que se desarrolla el deporte y de las representaciones culturales que éste y sus protagonistas, quienes lo juegan y practican, testimonian en los encuentros. La exploración del significado de los textos contrastado con lo escrito, lo observado y escuchado de los protagonistas pretende dar a luz a una nueva significancia de hechos y del deporte estudiado en tanto fenómeno de concreción social. Con un enfoque descriptivo vincularé las situaciones observadas, las narrativas recuperadas de las grabaciones de las entrevistas, las categorías tomadas de las encuestas, con las definiciones, conceptualizaciones y teorías de los autores elegidos para contrastarlas con el trabajo de campo.

Como instrumentos de recolección de datos se implementaron encuestas del tipo semi estructuradas de respuestas abiertas y cerradas, de carácter masivo que intentan alcanzar la mayor cantidad de casos posibles para lograr la saturación de datos. Se efectuaron entrevistas en profundidad tomando uno o dos participantes por equipo en forma aleatoria, que garantizan la representatividad de todos los equipos. Las entrevistas son de tipo espontánea, no guionadas o preestablecidas, a los efectos de recabar información sin que medie la pregunta o interrogación directa, pasando inmediatamente a su transcripción lo más fielmente posible. Se realizaron observaciones pasivas y participativas para destacar las interacciones entre los participantes; observaciones y anotaciones de campo de sucesos, circunstancias o manifestaciones que ilustran algunas de las descripciones y teorías reflejadas durante el estudio. Por último se explicita que se tomaron fotografías y se filmaron breves secuencias de distintos momentos de varios encuentros y jornadas deportivas, previas, durante el juego, en los entretiempos y post partido, que permiten ilustrar algunas de las escenas, secuencias y descripciones y asociaciones que puedan hacerse, que serán expuestas al momento de la presentación y defensa.

Respecto a la estructura de esta tesis, cabe expresar que en el capítulo I conceptualizaré y definiré categorías tomadas como palabras claves para el estudio, tanto en su aspecto analítico como sincrético, como en su significado e importancia social al fin 
de la indagación. Estas, inicialmente son: padres, deporte, fútbol, vínculos, relaciones, masculinidad, representaciones, salud. En este capítulo además esbozaré algunas de las teorías que sustentan el estudio y citaré algunos pensamientos de los autores con quienes trazaré algunas discusiones y puntos de encuentro en tanto la realidad observada.

En el capítulo II daré cuenta de los datos recabados a través de las encuestas realizadas a lo largo del año 2013, durante la realización de los encuentros en los días domingo por la mañana. Las entrevistas, por su parte, permiten ampliar algunos de los conceptos que se vierten en las encuestas e incluso advierten ciertas contradicciones entre los discursos manifestados y los hechos consumados. Las observaciones y las notas de campo ponen la mirada sobre los aspectos no declarados pero muy manifiestos en cuanto a los comportamientos, hábitos, códigos y discursos derivados de las interacciones de los sujetos participantes.

En el capítulo III realizaré un análisis de los datos a la luz de las teorías que sustentan el estudio. Los datos serán atravesados por la teoría y se establecerán certezas y analogías y discrepancias y contradicciones. Se expresarán notas de cómo algunas ideas de los autores se ven reflejadas en las manifestaciones concretas de los sujetos protagonistas o en su defecto, como ésta práctica en particular se contrapone a alguna de las teorías enunciadas.

Por último, en el apartado final destinado a las conclusiones y reflexiones de la tesis, expondré un punto de vista que sin ser definitivo, permita dar cuenta de algunas interpretaciones en relación a cómo se desarrollan las relaciones, vínculos y representaciones entre padres a través de la práctica del fútbol. Procuraré establecer relaciones asociadas a las categorías enunciadas como claves y proponer una teoría que explique las mismas o al menos de pie y paso a nuevas problematizaciones sobre el campo de estudio, despierte el interés por posibles próximas investigaciones que habiliten nuevas instancias de indagación de otros aspectos que se desprendan de ésta, o bien profundizar algunos desarrollados en la misma. 


\section{CAPITULO I}

\section{Capítulo I - Conceptualizaciones y categorías}

Definido el tema propuesto a investigar, problematizarlo de tal manera que permita clarificar que es lo que me gustaría indagar y decir de esta experiencia, no es tan difícil determinar cuáles son los conceptos claves que corresponde conceptualizar y teorizar y que permitan dar cuenta de las interpretaciones que haré sobre ellos.

Resultan trascendentes para este estudio definir en forma primaria y luego de modo analítico según su grado de correspondencia, reiteración y recurrencia, los siguientes conceptos: padres, deporte, fútbol, vínculos, relaciones, masculinidad, representaciones y salud.

La palabra padres determina claramente el universo de personas a estudiar, circunscripto a aquellos que participan del Torneo de Fútbol. La considero sustancial por cuanto es condición única para la participación en la práctica deportiva investigada. Todos los participantes son y deben ser padres de alumnos de las escuelas a las cuales representan. Es una condición común y exigida a todos los participantes y como tal incluye concepciones implícitas de sexo y género, de hombre y masculinidad, de configuraciones muy particulares dado el segmento sociocultural y económico al que pertenecen.

El deporte en general y el fútbol en particular, como la práctica social que reúne y nuclea a estos adultos. Existen concepciones diversas acerca del deporte y del fútbol sobre todo en nuestro país donde el fútbol aparece como la manifestación popular y deportiva por excelencia. El análisis acerca de cuál es la idea de deporte, de cómo se debe y en concreto cómo se desarrolla esta práctica en este contexto, puede explicar por qué es la elegida, modificada y adaptada por los sujetos que la practican. Cuáles son sus búsquedas, motivaciones, alcances, logros y satisfacciones que derivan de ella.

Los tipos y características de vínculos y relaciones que suceden en estos encuentros es lo que se quiere analizar, caracterizar y conceptualizar. Siendo integrante de uno de los equipos participantes en forma originaria he pasado por distintas 
experiencias sumamente valiosas de compartir, explorar e interpretar como suceso relevante de las prácticas deportivas, más allá de la anécdota personal.

Considero importante para mí, mis compañeros de equipo y el resto de padres de otras instituciones que conozco y he conocido a partir de la participación en este Torneo de Futbol, haber encontrado un espacio social donde se generan nuevas relaciones y vínculos con personas que comparten muchas ideas y vivencias generacionales, pero a su vez se desempeñan en ámbitos, trabajos, funciones y tareas tan disímiles que hacen sumamente rica la experiencia de conocernos y aprender unos de otros en los más diversos planos de la vida misma.

Al ser el Torneo de Fútbol un complejo de experiencias de desarrollo sistémico, ideado, organizado, implementado, protagonizado por hombres, se hace necesario entender la lógica del pensar y hacer de los hombres. De allí que adentrarse en el concepto de masculinidad es imprescindible a la luz de la interpretación de los hechos que suceden y se reiteran en cada encuentro.

En cuanto a las representaciones, su abordaje permitirá visualizar cuanto de real imaginario y simbólico ponen estos hombres en juego en el desarrollo de estas prácticas. La práctica deportiva es un escenario donde confluyen muchos aspectos de la vida de los sujetos y del hombre (masculino) en particular, muchos supuestos de cómo debe ser y cómo realmente es su comportamiento, cuánto de fantasía e imaginación depositamos en el acto deportivo, que significancia tiene para los sujetos estudiados, la misma práctica. Cuáles aspectos de nosotros mismos y de los demás nos permite ver, sentir y percibir el desarrollo activo y protagónico de la práctica del deporte.

La salud aparece como un concepto recurrente en el discurso de los sujetos participantes, tanto para describir situaciones motivacionales para el desarrollo de la práctica del fútbol, como para justificar su participación en el torneo. Considero importante confirmar si esta práctica deportiva elegida es ciertamente saludable para el grupo de personas que lo practican, dada su edad, sexo y condición física. Cuál es el concepto de salud que conocen y esperan desarrollar y fortalecer con esta práctica. Cuáles son los aspectos desconocidos acerca de los esfuerzos y acciones que de esta práctica devienen y cuáles son los riesgos, cuidados y acciones preventivas que debieran tenerse en cuenta. 


\subsection{Padres}

En un concepto amplio pero a la vez circunscripto a la condición masculina en lo referido al requerimiento para la participación en el Torneo de Fútbol conformando parte de la comunidad de la misma escuela. Siendo un Torneo de Fútbol para Padres (tal es su nombre, razón y título de la página web) ${ }^{2}$; considero que la categoría padres debe ser abordada en tanto condición estricta y propia del Torneo y en tanto configuración social común para los propios participantes. Es decir, la figura de padre (más allá del concepto obvio del parentesco filial) desde la masculinidad y de lo que significa ser padre de un alumno de una determinada comunidad escolar.

En la civilización occidental actual, más precisamente en el núcleo social estudiado, la construcción de la unidad familiar recorre varias posibilidades en tanto familias, consolidadas, sostenidas, separadas y rearmadas. No solo en la procreación y en la crianza de los niños se apuesta a un futuro que nos trasciende en la individualidad, donde la salud, la felicidad y la vitalidad de la familia sería la vara con que la mujer o el hombre o una clase social midan su éxito.

La condición o necesidad actual de la mujer trabajadora o profesional fuera de la casa y no sentenciada a la tarea de ama de casa y señora del hogar, ha distribuido necesariamente la labor y la inevitable presencia del hombre-padre como figura familiar en la crianza de los hijos. Esta nueva presencia en el hogar y en el rol de padre abocado a tareas de la formación de sus hijos dentro de la casa y el seno familiar, constituye para el hombre un mayor compromiso con las actividades en las que están involucrados sus hijos.

La procedencia del término padre es del latín, del vocablo pater, patris, cuya definición es aquél que es cabeza de familia y de la generación anterior. Desde una visión netamente biologicista, un padre es un varón o macho que ha engendrado un hijo con una mujer o hembra; o bien adoptado la función paternal, es decir ha adquirido una responsabilidad social y cultural al recurrir a una adopción de un hijo. La función de padre por lo tanto excede la cuestión meramente reproductiva, se trata de una figura clave en el desarrollo del niño, ya que debe protegerlo, educarlo y ayudarlo en las distintas etapas de su crecimiento.

\footnotetext{
${ }^{2}$ Ver torneocampitovn.blogspot.com: TVN Torneo Virgen Niña Fútbol para padres.
} 
En el niño, la función paterna instaura la ley, el orden, el logos. Siendo esta función paternal del orden de lo simbólico (Lacan, 1953); da lugar a un pensar racional que ordena y organiza la información procedente del registro de lo imaginario y el registro de lo real y permite una comunicación relativamente coherente entre los sujetos, no solo instaurada en la gramática del lenguaje, sino además por la significación de los hechos y la palabra que los describe.

La paternidad incluye una función de autoridad, de cuidado, de protección, de nominación y potestad (ya que el hijo lleva el apellido del padre y le pertenece la transmisión de sangre de herencia "natural" de familia-derecho romano-); económica (es decir de garantizar la manutención de los hijos y la transmisión de bienes y patrimonio) y una función cultural, social y afectiva.

La dinámica social de nuestro tiempo ha cambiado radicalmente y con el desarrollo de la mujer en el ámbito profesional, político y social, las actividades relacionadas con la crianza de los hijos y las acciones domésticas del hogar se hallan más repartidas entre los adultos a cargo del grupo familiar. En este sentido, hay que destacar, que la dinámica de la conformación de las familias también ha cambiado, ya que no son tantas las familias conformadas y sostenidas originalmente; sino que su conformación se ve alterada por, la cada vez más frecuente y común separación de los progenitores y la reformulación de familias ensambladas, donde el rol de padre o madre pasa a ser enarbolado por otro. Se han diversificado tanto las modalidades de las estructuras familiares posibles, que hoy nos encontramos con familias de tipo pluriparentales, multiparentales, monoparentales, coparentales, biparentales, homoparentales, todas legales, legitimadas y mejor o peor vistas en los diferentes contextos sociales, pero sin ninguna duda reales.

Claramente aceptada como modalidad de nuestro tiempo, el nuevo orden familiar establece nuevas formas de relación entre padres y madres de relación sanguínea y los padres y madres adoptados por los hijos en las familias ensambladas. En este campo, la paternidad responsable hace referencia a las contribuciones del tiempo que los hombres puedan aportar para la reproducción y sostenimiento emocional del núcleo familiar. Con este factor se introduce una dimensión cualitativa referida a la dinámica familiar que permite visualizar los aportes no monetarios que los hombres pueden hacer en la crianza de los hijos, y a las contribuciones de orden cultural, social y afectivo en los nuevos modelos de crianza compartidos. 
Además de la lógica relación filial, la idea de definir en los tiempos que corren el significado de ser padres en tanto relación social masculina no solo con el hijo, sino en relación a los vínculos emergentes por caso de pertenecer a tal categoría.

La relación de pares adultos sujeta a la escolaridad de los niños, está popularizada como aquella que realizan las madres como encargadas supremas de velar por la educación de sus hijos, como una tarea más de aquél matriarcado del hogar heredado desde el siglo XIX en los países de América colonizados por los europeos. Dentro de estas nuevas formas de relación, una de las variables más genuinas de aceptación para un padre también estaría dada por su intervención en las situaciones escolares de hijos, sanguíneos, adoptados o aceptados. La vida escolar abre puertas a la vinculación de las familias a las que pertenecen y en las cuáles se reflejan determinados valores y principios que se manifiestan en los idearios de las instituciones educativas y que son compartidos por las familias que las eligen para confiar en ellas la educación de sus hijos. En este contexto, el Torneo de Fútbol para Padres habilita una nueva dimensión para el desarrollo de estos vínculos sociales entre las familias que mandan a sus hijos a las Escuelas y Colegios de la zona de influencia del Torneo.

Establecer algunas características de las singulares relaciones que se manifiestan en estos grupos de padres, debe hacer referencia ineludible a los tipos de relaciones asociadas al concepto de masculinidad y a cuáles de estos comportamientos característicos de la masculinidad argentina, estarían presentes a través de la práctica deportiva del fútbol en la población estudiada.

\subsection{Masculinidad}

Las diversas imágenes y formas de conducta comprendidas en el concepto de masculinidad son muy amplias y no podrían tratarse como estables o universales, dada la dinámica social de nuestro tiempo. No existe una sola forma de ser hombre, pero si existen maneras dominantes de serlo que plasman modos de comportamiento esperables.

El autor Eduardo Archetti (2003: 157-160) hace referencia a un trabajo de Gilmore (1990) quien enfatiza la universalidad de valores tales como la fortaleza, la agresividad, el estoicismo y la heterosexualidad, en la definición del arquetipo de la hombría y la virilidad; 
y a Moses (1985), quien describe el desarrollo histórico de clases medias dominantes basado en la importancia de la virilidad masculina, el vínculo homo-social masculino, la ferviente hermandad y en consecuencia ver a la homosexualidad como una amenaza. La presencia femenina es necesaria para cumplir el rol familiar de la maternidad, para realzar la masculinidad del hombre; mientras que en ellos, la virilidad sería más relevante que la paternidad, hablando siempre de los tipos de dinámica familiar tradicional.

Sam Keen (1992: 269) describe que en las últimas generaciones,

con las familias integradas por hombres y mujeres, padres y madres al mundo del trabajo; se ha ido perdiendo la discusión de género en relación a nuestro destino biológico y espiritual de progenitores, de qué se debe ocupar cada uno y de cuáles aspectos se ocupa el otro. Un niño aprende a "ser hombre" y a "hacerse hombre" observando e imitando a su padre en su comportamiento social: en el trato con la mujer y con otros hijos, con los pares, y con los hijos de sus pares, con los mayores, con extraños.

En diferentes circunstancias, informales, familiares, amistosas y relajadas, y en ocasiones formales, serias o penosas, el niño o el joven aprende los comportamientos en el éxito, el valor, el placer y la confianza como en la violencia, la agresión, el fracaso, el abuso y la desesperanza; la relación con el padre refiere a la constitución con el afuera, lo externo, con el otro, con los demás.

Estos rasgos de masculinidad dominante constituyen un poderoso estructurador de identidades individuales y sociales masculinas. Externa y preexistente al sujeto como una identidad a implantar y a adjudicar durante un proceso de atribución del género, tiene en su seno los valores y contra valores a los que hay que acercarse y alejarse respectivamente para ser ese hombre deseable. Este hombre al que debe aspirarse ser, queda profundamente impregnado en el modo de existir masculino y empuja constantemente a querer serlo. También queda fraguado en el modo de pensar femenino en cómo debe ser un hombre.

Esta conceptualización nos lleva al concepto de género, definido como una construcción cultural del orden de lo simbólico mantenida y reproducida por las representaciones dominantes y naturalizadas de lo considerado propio de cada sexo. Es a partir de las características contrapuestas que culturalmente se otorgan a hombres y mujeres sustentadas sobre su diferente fisiología, que se establecen un tipo de relaciones 
sociales basadas en aptitudes, habilidades , trabajos, sentimientos, colores, olores, vestimentas, comportamientos categorizadas como de género masculino o femenino. El ser mujer o el ser hombre, son del mismo modo categorías construidas que se corresponderán a nivel ideológico con lo que una sociedad como la nuestra, considera femenino o masculino ${ }^{3}$.

Es ésta una matriz generativa que va moldeando y limitando un formato, un sistema organizado, normativo, complejo y de carácter absolutista y excluyente por lo que el cuerpo social donde ese sujeto habita ordena lo que debe y no debe ser un hombre. A su vez, es también un mapa orientador que va indicando el camino, dando señales, mostrando mojones de instancias y pasos alcanzados, tramos y trayectos por lograr, destinos a los cuáles llegar, sustentados en ideologías que proponen modelos de sujetos masculinos valorados por la cultura occidental ${ }^{4}$.

Son estos valores y sus manifestaciones visibles en las acciones de dominancia, del poderío visible, de la actividad racional por encima de la emotiva, de la individualidad, de la eficacia y la eficiencia, la voluntad de poder, la certeza y claramente, la predilección por la heterosexualidad. Estos valores se definen como importantes y valiosos socialmente, y por serlos, se adjudican a los hombres, ya que según la ideología patriarcal, ellos son los jerarquizados, aún en este sistema social moderno y crítico donde la mujer va ganando cada vez mayores espacios. Propuestos culturalmente como norte de la acción masculina, se presentan además como una meta de realización, cerrando así un círculo de autocomplacencias y auto apropiaciones, donde todos acuerdan su prevalencia y trascendencia.

Entre las creencias y supuestos acerca de la masculinidad, de lo que corresponde al hombre ser, creer y sentir, se afirman las cualidades de autonomía, independencia, el poder sobre sí mismo y sobre los demás, autoafirmación, autoconfianza, libertad, poder, prestigio, trascendencia, ambición y éxito, resultados y control, son algunas de las

\footnotetext{
3 "El género asigna los papeles y las funciones que se consideran más apropiados para cada sexo, determinándose pues la configuración de la propia identidad femenina o masculina en una cultura" (Tellez, Anastasia y Verdú, Ana Dolores, 2011)

${ }^{4}$ Una, la ideología que propone al sujeto hombre-padre con poder sobre los hijos y mujeres y afirma el dominio masculino del mundo. Otra, la ideología del individualismo de la modernidad, para la que el sujeto ideal es autosuficiente, capaz, racional y hace a su voluntad.

La tercera ideología es la de la exclusión y subordinación del otro, posicionándose como ser superior y la cuarta la del heterosexismo homofóbico que propone como sujeto ideal al que realiza prácticas heterosexuales y rechaza las homosexuales. $Y$ en tanto lo humano aparece en estas ideologías, quedan finalmente definidas como valores masculinos (Bonino, L., 2002: 13).
} 
búsquedas permanentes de los hombres de nuestra sociedad actual. Los valores vehiculizados, manifestados y priorizados a través de esta posición son de vertiente autorreferente y egocéntrica, es decir son impuestos a sí mismos y jerarquizados por los mismos hombres.

En este panorama la convivencia entre hombres plantea relaciones no siempre tan fluidas, cómodas ni recíprocas. El lugar adjudicado al otro no es de sujeto igual, sino preferentemente de sujeto diferenciado en menos, de menor valor, a proteger o a vencer, fomentando una actitud que lo aleja de su par. El carácter de luchador heroico promueve la figura de héroe, el soldado o el guerrero valeroso o en el contexto estudiado, la versión del deportista. La búsqueda del sentido de la vida por la lucha y el sacrificio, el triunfo y el reconocimiento de sus iguales promoviendo así un paradigma basado en transitar caminos de hazañas y proezas, una visión de la vida como un desafío, y del mundo como un campo de batalla en el que gana el más fuerte y donde la amenaza es constante, en el que la violencia puede ser requerida en algunas de su formas más atenuadas y en la que está en juego el emblema de la masculinidad dominante: ser más que el otro. Desde esta perspectiva, el lugar adjudicado al otro es el de un sujeto no confiable, potencial adversario o humillador, peligroso, oponente a doblegar, enemigo o competidor, se construye la propia seguridad a costa de definirlo como enemigo. Ganar es someter al otro y lograr su respeto a partir de vencerlo en la justa deportiva. El valor de la jerarquía se afirma al adquirir un lugar superior dentro de la estructura vertical de poder masculina, o cualquier otro referente simbólico semejante. De estas configuraciones se desprenden otro tipo de manifestaciones ligadas a la subordinación, la obediencia, la disciplina y la lealtad, al ejercicio de la autoridad, del saber y poder del adulto, la sujeción a las normas, al sacrificio propio por el bien grupal y común.

Por otro lado, el carácter masculino promueve también la competitividad, que en sus raíces lo es por ver quién es "más hombre", y que en el deporte, este rasgo logra magnificarse. Algunos valores manifiestos y promovidos a través de la práctica deportiva son la capacidad de lucha, la voluntad por superarse a sí mismo, la agresividad controlada, el atrevimiento y la audacia puestos en el juego, la tolerancia al sufrimiento y al dolor por encima del placer de la práctica misma, el uso del cuerpo como herramienta, el cuerpo bien formado y constituido, preparado para la contienda, la dureza emocional y la alta concentración; la preparación para enfrentar al adversario. 
Un enfoque restringido a ciertos terrenos sociales nos permite indagar como la masculinidad se produce y reproduce en modos diferentes. Estos terrenos se constituyen como complementarios y opuestos a lo femenino, pero también hay contextos de preponderancia eminentemente masculina, donde "los otros" relevantes son los hombres, distintas clases de hombres. En este sentido son varios los campos donde podríamos abordar comportamientos y expresiones del mundo masculino: el trabajo, la familia, las amistades, la política, y por supuesto el de nuestro caso, las prácticas deportivas. ${ }^{5}$

Formar parte de un grupo, de un equipo, la representatividad de una institución, el sentimiento de trascendencia más allá de sí mismos, y la misión de resguardar un espacio íntimo y propio pleno de esencias, saberes, códigos y discursos masculinos parecería ser una meta para estos adultos que se afianzan, buscan y descubren nuevos lazos de masculinidad a una edad donde la competencia y la rivalidad se destacan en las relaciones cotidianas casi en todos los espacios de interacción social.

\subsection{Deporte}

Siendo una práctica reconocida en las más variadas culturas del mundo, el deporte provee un campo fértil para el abordaje de diferentes tipos de estudio. Desde una mirada más superficial el deporte es tratado en su parte más analítica a través de la literatura periodística en cuanto a la utilización de tácticas, estrategias, movimientos y desempeños de sus protagonistas, por lo general de los profesionales que lo toman como medio de vida y obtienen sus remuneraciones por ello. Esto ayuda a la mercantilización y a la venta del producto en cuestión para el consumo de la masa de espectadores, ávidos de este tipo de información de carácter superfluo. Una mirada crítica en cuanto al uso del deporte por parte del Estado, como instrumento de control de las masas enfoca la discusión en los efectos populistas de su práctica y su consumo. Dado su atractivo mediático, amplia accesibilidad y naturaleza común como actividad de todos los pueblos, paradójicamente puede, en relación a la significación que cada deporte despierte en los habitantes de cada país o región en que se desarrolle, convertirse en parte de la cultura popular de los pueblos (Archetti,1984). Así las configuraciones que contienen las prácticas en las

\footnotetext{
5 "La masculinidad se produce a partir de una materialidad, una determinada manera de vivir, sentir y poner en funcionamiento el cuerpo, sancionado dentro de unas instituciones culturales (como el deporte o el mundo del trabajo)" (Connell, 2003: 46).
} 
diferentes regiones son particularmente atractivas y significantes para cada uno de los pueblos y desarrollan procesos de creación de identidades claramente reconocibles ${ }^{6}$.

En la obra "Sociología del deporte" (García Ferrando, Puig Barata, Lagardera Otero compiladores, 1988) se exponen las perspectivas teóricas más utilizadas en los estudios sociológicos acerca del deporte:

La explicación funcionalista justifica la existencia del fenómeno deportivo en términos de sus consecuencias y más en concreto de su contribución al funcionamiento de un orden estable. Sus conceptualizaciones propenden a ser prescriptivas, ya que tienden a una acción benévola y necesaria, que refuerza y sostiene el régimen social vigente en busca de su inevitable equilibrio. Jhon $W$. Loy concibe el deporte como un juego institucionalizado característico de un modelo cultural y una estructura social que se ha consolidado, cuyos elementos incluyen valores, normas, sanciones, conocimientos, roles y estatus sociales; constituyéndose como una de las manifestaciones más genuinas del sistema, con la función de integrar a él, multitudes de personas que lo practiquen o consuman. Además puede ayudar a la formación de identidades nacionales, regionales o grupales (Mc Pherson, 1978), ofrece la oportunidad de proyectar tensiones y ciertos niveles de agresividad y armonizar divisiones del sistema social, logrando procesos de integración y socialización (Kenyon, 1986).

Desde otro punto de vista, el conflicto de intereses domina la escena de la vida social de los hombres, donde la interacción constante y la lucha por estos intereses y el poder conducen al cambio y a la dinámica social permanente (Giner, 1974). La teoría marxista del conflicto, sustentada en la idea del materialismo histórico, la primacía de las estructuras económicas, la determinación histórica de los fenómenos sociales y el reconocimiento de los cambios sociales revolucionarios junto a los evolutivos; llevadas al deporte proponen que este es un producto genuino de la revolución industrial y del nuevo orden social impuesto por la burguesía, constituyendo un refuerzo positivo e ideológico del capitalismo que hace posible que las relaciones de dominio y poder sigan inalterables (Brohm, 1978).

El deporte conceptualizado desde la sociología figurativa de Norbert Elías y Eric Dunning mediante la cual intentan superar la arbitrariedad de distinguir entre individuo y

\footnotetext{
${ }^{6}$ Como ejemplo, pueden ofrecerse el rugby en Oceanía, Nueva Zelanda, Australia, Fiji; el fútbol en el Río de la Plata, Brasil y Sudamérica toda y el Beisbol en los E.E. U. U. y el Caribe.
} 
sociedad, teoría de los procesos de civilización, que desde una perspectiva histórica de larga duración, devela los cambios en los usos sociales que ha ido construyendo la modernidad. El nuevo orden social auspiciado por la burguesía, aviva el surgimiento del Estado moderno capitalista y parlamentario, quién sancionó su derecho monopólico al ejercicio de la violencia; en este contexto socio histórico es cuando emerge el deporte moderno, como acomodación moderada a los otrora violentos sports populares ingleses. La aportación sustancial de los autores radica en la consideración de que el deporte lejos de significar un pasatiempo inocuo e intrascendente, es una más de las claves sociales que nos permiten comprender el origen y la evolución de los tiempos modernos. "La violencia que se registra actualmente en el deporte, es una consecuencia propia de una sociedad pacificada" (Elías, 1992: 27-28).

La perspectiva estructuralista del deporte, considera los fenómenos culturales como signos, que constituyendo sistemas, son susceptibles de ser analizados para conocer sus estructuras. Una vez conocidas estas pueden ser formuladas como modelos teóricos que son capaces de hacer inteligible la realidad. "Los deportes no se inscriben en un marco aparte de la sociedad, sino que es necesario estudiar el sistema deportivo en el conjunto del sistema social" (Bourdieu, 1988: 176). Este método ha sido muy utilizado por el autor en sus trabajos en el ámbito de la sociología del deporte francesa. Para este sociólogo francés, los gustos por las distintas prácticas deportivas se hallan determinados por la adscripción de clase, así los deportes de mayor contacto físico han sido realizados casi exclusivamente por las clases más desfavorables, mientras que los deportes de distancia o donde medie un instrumento para su desarrollo, han sido practicados por los sectores aristocráticos.

La mirada de los interaccionistas en el deporte brinda nuevos aportes, sobre todo en la dinámica tan cambiante de la sociedad contemporánea. Esta corriente estudia las formas mediante las cuales las personas otorgan significados a sus cuerpos, sentimientos, biografías, situaciones y en general a los contextos sociales que habitan en una especie de tejido dinámico y dialéctico en proceso de cambio permanente. El alemán K. Weis pionero de esta corriente de estudios en el deporte, realiza una distinción importante para la comprensión de la significación social de los deportes en cuanto a los términos de Asociación (en la cual funcionaríamos como miembros activos); Institución (en la cual estaríamos sometidos a sus reglas), y Organización (cómo órgano ejecutivo de las Instituciones con modelos de conducta institucionalizados y naturalizados). El deporte 
ostenta muy distinta significación según diferentes grupos de personas, en especial si estas responden a diferentes patrones culturales (Weis, 1990:19).

Los últimos trabajos etnográficos en relación al deporte han centrado su interés en los sentimientos, emociones y percepciones de protagonistas y espectadores de la práctica deportiva, donde se detecta que las emociones desarrollan un itinerario de asignación de atribuciones, de significados a los sucesos relacionados con la práctica del deporte, que va variando a través del tiempo (Puig y Morel, 1996: 448).

Para Ortega y Gasset (1961: 17-18) en la vida hay dos tipos de actividades: "una de naturaleza utilitaria y organizativa donde el esfuerzo es obligatorio, y otra vigorosa, vital y creativa, donde el esfuerzo es una delicia, voluntariamente escogida". Lo esencial de la vida reside en el segundo tipo, en el desarrollo de actividades por la búsqueda del placer donde el deporte es la manifestación más exaltada de esta idea.

Asladair Mac Intyre (1987: 233) considera el deporte en el concepto de práctica como actividad cultural.

Es una forma coherente y compleja de actividad humana corporativa, mediante la cual se realizan los bienes inherentes a la misma, mientras se logran los modelos de excelencia que le son los propios. Existen los bienes extrínsecos al juego (fama, poder, dinero), se compite por ellos pero también se buscan los bienes intrínsecos (jugar bien, regates, fintas, remates, la excelencia).

Lejos de poder ser explicado en forma acabada y completa por cualquiera de estas corrientes, el deporte contemporáneo se nos presenta como un sistema abierto y cambiante en forma permanente (Heinemann, 1991).

Si bien hay acuerdo en tanto la importancia del deporte en el contexto mundial a raíz de su fuerza expansiva multiplicada por la influencia de los medios de comunicación masivos, los intereses y producción económica que derivan de él en todo el planeta, también encierra singularidades vinculadas a la condiciones culturales, económicas y políticas de los diferentes contextos donde se practica. Consenso, acuerdo social o justificación universal, en una abierta crítica razonada y plural que aprecie diferentes posiciones, parecería ser la realidad del deporte, un fenómeno que pueda resistir una mirada referencial múltiple para su análisis y problematización, y que pueda clarificar ciertamente cuáles son sus aportes más genuinos a la sociedad (Simon, 2006).

El deporte y más precisamente el fútbol, funcionaron y funcionan como modelos y espejos de identidades y representaciones del hombre esperable de nuestro país. Así por ejemplo, la forma en que se estructura socialmente el fútbol, probablemente el más 
popular de todos los deportes en el mundo y el alcance del espectáculo que éste genera en términos de consumo, se encuentra íntimamente ligado al tipo de sociedad en que se desarrolle. Asociado al concepto del sport de origen inglés, dentro de él, el fútbol en particular, reconocido deporte popular en la Argentina y en Buenos Aires especialmente, veremos cómo ha sido el proceso de instauración, relevancia, protagonismo y arraigo del fútbol en nuestro país, y por qué es el elegido por la población estudiada en el caso.

Según el autor Eduardo Archetti los procesos de hibridación son la mezcla de tradición y modernidad de marcos transdisciplinarios de la cultura, donde el deporte cumple un papel fundamental sobre todo en los países latinoamericanos en general, y del fútbol y los argentinos en particular. Definido éste, el fútbol, junto a otras típicamente argentinas como por ejemplo el polo y el tango, como prácticas corporales modernas y en un mundo globalizado, son expresiones reales de las capacidades y potencialidades nacionales casi o más influyentes que el arte y la literatura (Archetti, 2003).

A fines del Siglo XIX Inglaterra se posicionó excepcionalmente en Europa como el arquetipo de sociedad virilizada a través del deporte de conjunto, que se encargó de exportar a nuestro continente. Nuestro país, particularmente, adoptó el fútbol como deporte popular, desarrollando este proceso de hibridación (Archetti, 2003) entre el juego entre gentleman y fairplay traído por los ingleses y desarrollado en las high school, y el juego espontáneo, libre y aguerrido de los jóvenes criollos practicado en los potreros.

Estos estilos estarían basados en las diversidades étnicas conceptualizadas como diferencias de carácter y en la manera de expresar sentimientos y manifestaciones motrices. Así el estilo británico comulga con la disciplina, el método, la fuerza y los ideales colectivos de equipo. Estas virtudes ayudan a crear una forma de juego industrializada, repetitiva, casi perfecta como una máquina. El estilo criollo, con fuertes influencias latinas migratorias es lo opuesto, espontáneo, impredecible, basado en la habilidad y creatividad individual.

Esta contradicción se refuerza en el acto de acceso y aprendizaje del fútbol en las prestigiosas escuelas inglesas a cargo de maestros especializados, y en el ámbito de la libertad y la espontaneidad de los potreros de los suburbios urbanos y campos rurales, donde hasta las imperfecciones y desniveles del terreno, la falta de líneas y arcos, favorecía el desarrollo de la creatividad de los jóvenes para superar los obstáculos.

A sí mismo, este estilo de jugar "a la criolla", a "la nuestra", se reconoce hoy como la manera de jugar bien. Jugar bien al fútbol para los argentinos no significa ganar, sino 
obtener el triunfo respetando el estilo de juego de acciones breves, precisas, demostrando habilidad y elegancia con la pelota, juego asociado de pases cortos y vertiginosos y contundencia para marcar goles; "construir paredes", (en la jerga popular, otra clara alusión al trabajo de albañilería y a la raíz social de pertenencia del juego, donde la presencia del otro ayuda al logro final por la eficacia y precisión de la tarea manual, de tipo artesanal, no mecánica o industrializada).

Tampoco se debe menospreciar la rudeza y el vigor en la disputa de la pelota y en la defensa de su valla como símbolo de virilidad y masculinidad. Este aspecto lo simboliza como el deporte fundamental en la Argentina porque lo emparenta con la representación de la Nación en la figura de la Selección Argentina de Fútbol ${ }^{7}$.

Nunca resultó fácil entender e interpretar la idea de ser nacional argentino, en tanto es una identidad construida a partir de sus habitantes originarios, enriquecida por un sumamente heterogéneo movimiento migratorio de todas partes del mundo. Sin embargo, aparece como una clara visión la de encontrar un estilo de juego argentino en el fútbol. El fútbol argentino posee un ADN claramente identificable en el resto del mundo. Sus jugadores son reconocidos por su enorme habilidad con la pelota, su capacidad de "gambetear" (voz gauchezca que deriva de la forma de correr del ñandú), de eludir rivales a través de un recorrido vertiginoso e impredecible con control de la pelota, por su coraje e intensidad que le propinan al juego y cierto dejo de rudeza.

Este modelo es de suma importancia en cuanto a la percepción del fútbol como modelo de interpretación en el campo social y simbólico que ubica a la Argentina y a los argentinos en la escena global y para el caso de éste estudio, en la escena local.

El desarrollo de las distintas técnicas del juego, pases, paradas, quites, control y dribling, remates, la habilidad de jugar el balón con diferentes partes del cuerpo, las destrezas especiales como "rabonas", "chilenas", "taquitos", los lujos que demuestran el grado de maestría alcanzado por los que juegan, constituyen los bienes internos del fútbol; y quienes juegan demuestran cierta jerarquía sobre los demás si logran manejarlos

\footnotetext{
${ }^{7}$ A partir de la consolidación de un estilo de fútbol argentino, se comienzan a "exportar" (a Europa fundamentalmente), jugadores de fútbol que se identifican con él, y la constitución de una Selección de Fútbol que representa al país con importantes éxitos deportivos en resultados y en trascendencia por la valoración externa de su juego (junto con la de los uruguayos, en lo que se llamaría "futbol rioplatense"); la Argentina pasa a ser conocida en el mundo por un producto popular, más allá de sus carnes y cereales vinculadas a los terratenientes y chacareros de la elite social y económica. A partir de allí, modificado, enriquecido, cambiante se genera un estilo o forma de juego argentino, que se identifica como propio, genuino, que funciona como modelo o espejo de los argentinos en torno a su manera de ver, entender, vivir y sentir la manera de jugar al fútbol. (Archetti, 2003)
} 
con soltura, facilidad y eficacia. Los que carecen de la experiencia pertinente no pueden juzgar acerca de los bienes internos y esto ya marca un posicionamiento de valor en los grupos y equipos. Jugadores y aficionados que conocen bien el fútbol y sus reglas, supeditan sus intereses a tales bienes y aún si su equipo se ve desfavorecido, va a admitir las carencias antes de poder superarlas (Mac Intyre, 1987). Hay equipos que se conforman y complacen con jugar bien al fútbol si cuentan con jugadores de gran habilidad y destreza y otros que valoran sus resultados en función de las limitaciones técnicas que poseen.

Las características de los híbridos masculinos producidos en el futbol argentino, producto de la fusión con los inmigrantes y criollos y por supuesto del estilo inglés; tenían una cualidad transgresora ya que podían enfrentar el modelo dominante basado en las virtudes masculinas y el estilo de juego inglés; el estereotipo de hombre moderno fue (y es) desafiado por el estilo argentino, como opuesto y excluyente a lo británico (Archetti, 2003). En las sociedades modernas, el deporte, los juegos y el baile son sitios privilegiados para el análisis de manifestaciones plenas de libertad y creatividad cultural. Estas acciones devenidas de los propios protagonistas, tienen el encanto de la aceptación o el repudio popular en tanto estén o no alineadas a ese imaginario en construcción permanente. De esta manera, también adquieren una valoración intrínseca por como son vistos para la sociedad local y una valoración externa por como son asociados con la comunidad global en tanto respondan o no a esos estereotipos de identidad argentina. Es decir precisan de la validación y de la legitimidad propia y del otro, de la mirada interna y de la externa.

$Y$ aquí es donde precisamente, los grupos que se identifican con determinadas pautas de comportamiento, formas de juego, aceptación de reglas y condiciones de juego desarrollan un habitus propio que cuidan y conservan y es en éste contexto que hay que entender por qué estos hombres realizan la elección del fútbol como práctica deportiva que los nuclea. La preservación de este espacio, de esta práctica estudiada, pretende sostener en el tiempo diversas situaciones emergentes y particulares que se desarrollarán más adelante y que están asociadas a los vínculos, relaciones y representaciones de estos sujetos en relación a la práctica del fútbol.

\subsection{Salud}

La salud es un estado de completo bienestar físico, mental y social o de equilibrio, que se contrapone al de enfermedad, pero superior a la ausencia de alguna dolencia 
según la definición de la Organización Mundial de la Salud (OMS) en su constitución aprobada en 1948. En 1992 se amplió la definición al agregar "y en armonía con el medio ambiente" y fue ampliamente aceptada en la comunidad mundial.

Conceptualmente es una definición subjetiva, es una percepción propia de cada sujeto de su estado no solo físico sino además de la dimensión psicológica, social y emocional, al considerarse al mismo, a la persona, en forma integral. La salud (del latín salus - utis) ha sido considerada no como un estado abstracto, sino como un medio para llegar a un fin, como un recurso que permite a las personas llevar una vida individual, social y económicamente productiva. La salud es un recurso para la vida diaria, no el objetivo de la vida. Se trata de un concepto positivo que acentúa los recursos sociales y personales, así como las aptitudes físicas.

Todas las definiciones relacionadas al concepto de salud han sido cuestionadas ya que se la considera una definición ideal, por consiguiente no toda la población alcanzaría ese estado; hoy asumimos que la salud es un proceso en el cual el sujeto se desplaza sobre un eje salud- enfermedad acercándose a uno u otro extremo según se refuerce o rompa el equilibrio. La salud se concibe hoy, como la posibilidad que tiene una persona de gozar de una armonía biopsicosocial, en interacción dinámica con el medio en el cual vive.

Una de las claves de nuestro tiempo tendientes a preservar la salud y mejorar la calidad de vida es la práctica de actividad física ya que esta produce un estado de bienestar tanto física como anímicamente. El ejercicio físico puede expresarse como cualquier movimiento corporal reiterado con el propósito de mejorar o mantener algún aspecto de la condición física, sus capacidades condicionales y coordinativas (Serra, Viñas y Aranceta, 2006). El ejercicio físico regular es un componente necesario en la prevención de algunas enfermedades como problemas cardíacos, enfermedades cardiovasculares, diabetes, sobrepeso, dolores de espalda, entre otros. Debe practicarse con mesura y de forma equilibrada, prestando atención a los cambios físicos internos para aprender a comprender la relación causa-efecto entre el movimiento físico concreto y su efecto directo con los cambios percibidos, porque puede llevar a un desgaste físico de ciertas partes del cuerpo. Cabe insistir en el equilibrio de fuerzas, tanto internas como externas que deben considerarse, y a ello ayuda el autoconocimiento mediante un crítico autoanálisis en forma previa, durante y posterior a la competencia y de un apropiado examen médico que indique sus posibilidades y limitaciones en cuanto a la edad, sexo y estado de condición, en relación a la actividad física que se pretende realizar. 
Además de ser necesario para una salud equilibrada, el ejercicio o actividad física debe complementarse con una dieta equilibrada y una adecuada calidad de vida. ${ }^{8}$ La cantidad mínima recomendada por los médicos para prevenir enfermedades es de 30 minutos diarios de actividad física moderada. Otros hábitos que deben combinarse con la realización de ejercicios son: la buena alimentación, el descanso adecuado, la higiene y evitar el consumo de sustancias perjudiciales para el organismo, como el tabaco, el alcohol y otros estimulantes. Existen hábitos perjudiciales para la salud, son aquellos nodos de conducta que traen consecuencias nocivas y peligrosas para nuestro cuerpo tales como el sedentarismo (inexistencia de actividad física que provoca obesidad, exceso de colesterol, falta de comunicación etc.); mala postura corporal (sobretodo originadas por malas posiciones continuadas durante muchas horas de trabajo en oficinas, cajeros, etc.) puede generar trastornos crónicos y agudos; uso de drogas y estimulantes de todo tipo generan adicciones y dependencias que provocan graves alteraciones en todo el organismo; el abuso en el consumo de alcohol y tabaco son considerados graves elementos que atentan contra la salud de las personas.

Existe hoy en día consenso internacional en relación a establecer acciones de promoción de la salud. Este proceso consiste en fortalecer los conocimientos, aptitudes y actitudes de las personas para participar responsablemente en el cuidado de su salud y para optar por estilos de vida saludables, facilitando el logro y conservación de un adecuado estado de salud individual, familiar y colectivo; mediante actividades de participación social, comunicativa y educativa para la salud. A partir de distintas Jornadas, Simposios, Conferencias y Asambleas Internacionales desarrolladas en las últimas décadas se han promulgado documentos a los que adhieren la mayor parte de las naciones del mundo, donde se plantean los principios básicos y las acciones a llevar a

\footnotetext{
${ }^{8}$ Sus beneficios pueden resumirse en los siguientes puntos: aumenta la vitalidad, por lo que proporciona más energía y capacidad de trabajo; auxilia en el combate del estrés, ansiedad y depresión; incrementa autoestima y autoimagen; mejora tono muscular y resistencia a la fatiga; facilita la relajación y disminuye la tensión; quema calorías, ayudando a perder peso excesivo o a mantenerse en el peso ideal; ayuda a conciliar el sueño; fomenta la convivencia entre amigos y familiares, además de dar la oportunidad de conocer gente; reduce la violencia en personas muy temperamentales; favorece estilos de vida sin adicción al tabaco, al alcohol y a otras sustancias; mejora la respuesta sexual; atenúa la sensación de aislamiento y soledad entre ancianos; fortalece los pulmones y con ello mejora la circulación de oxígeno en la sangre; disminuye el colesterol y riesgo de infarto, y regulariza la tensión arterial; es eficaz en el tratamiento de la depresión; estimula la liberación de endorfinas, , y permite una distracción momentánea de las preocupaciones, con lo que se obtiene tranquilidad y mayor claridad para enfrentarlas más adelante. Puede profundizarse en Devis-Devis (2000) y Serra, Viñas y Aranceta (2006).
} 
cabo en cada región para la promoción y desarrollo de la salud mundial ${ }^{9}$.

Tres problemas centrales se plantean en relación a la salud en términos generales de la población mundial y el estilo de vida en el cuál vive gran parte de la comunidad mundial: el sedentarismo, el sobrepeso y el aumento de población adulta. Estos tres problemas pueden asociarse claramente a la población estudiada en tanto pertenecen a un orden social, a un ámbito profesional y laboral y a una determinada franja etaria que en alguna u otra medida los afectan. El sedentarismo hace más propensas a las personas a enfermar y a adquirir más tempranamente signos de envejecimiento. Este estilo de vida conduce al sobrepeso y el cuadro se agrava ante la extensión de la expectativa de vida por encima de los 80 años. La buena noticia es que el desarrollo de actividades saludables, entre ellos el ejercicio físico colabora directamente a contrarrestar los efectos de los males mencionados.

Saavedra (2000) propone en relación al ejercicio, la actividad física y la salud, un gasto en actividad física semanal de al menos 2000 calorías distribuidas en 2 a 4 sesiones por lo menos y en un porcentaje de $60 \%$ de ejercicios aeróbicos de baja intensidad, larga duración que favorezcan la reducción metabólica y oxidativa de grasas. El otro $40 \%$ debe ser proveniente de ejercicios de tipo anaeróbicos, es decir, de corta duración o intermitentes y de alta intensidad; cuyos umbrales y magnitud permitan que haya ciertas microlesiones o microfracturas que luego se reparan, quedan más fortalecidas y dan paso a la renovación de células y tejidos de nivel muscular y óseo.

Si existe un equilibrio entre el consumo y el gasto de calorías, no solo nos vamos a ver bien, sino que también nos sentiremos bien. En el concepto de salud de los sujetos estudiados, aparece como una constante este "sentirse bien"; el nivel de percepción de los beneficios de la práctica deportiva tiene mucho más que ver con las sensaciones de placer y bienestar psíquico y emotivo, que de las modificaciones y transformaciones físicas obtenidas a través de la práctica del fútbol.

Entre los estudios médicos más comunes para el diagnóstico y tratamiento del sobrepeso y de la obesidad, está el de la averiguación del índice de masa corporal, donde a partir de algunas mediciones se obtiene un percentil determinado. Durante toda la vida se recomienda estar dentro de índices de masa corporal ideal, este índice se obtiene dividiendo el peso por la talla en metros al cuadrado: P/T2 y el resultado debe estar entre

${ }^{9}$ Véase la "Carta de Ottawa para la promoción de la salud", Canadá, 1986; Conferencia de Adelaida, Australia, 1988; Conferencia de Sundsvall, Suecia, 1991, Declaración de Yakarta, Indonesia, 1997; Asamblea Mundial de la Salud desde1988 se reúne anualmente en la sede de la OMS, Ginebra, Suiza. 
21 y 24. La grasa no debe sobrepasar el $30 \%$ en las mujeres y el $25 \%$ en los hombres. El exceso de peso es evidente en la mayoría de los sujetos participantes, si bien no fue un dato relevado, de interés específico al tema de la investigación, claramente puede afectar (y de hecho lo hace) a cada persona en particular, en el desarrollo de la práctica deportiva.

El examen previo, completo, el adecuado diagnóstico de la condición física y la prescripción, recomendación y advertencias del plan de ejercitación y prácticas a seguir, es básico, fundamental y permitirá estipular los objetivos adecuados, los materiales y métodos que debe seguir el sujeto que quiera realizar actividades físicas relacionadas con el cuidado y mantenimiento de la salud.

Presentada esta conceptualización acerca de la salud, comprenderemos más adelante que difiere bastante de lo recuperado en este estudio, en tanto que la práctica deportiva del fútbol, en adultos de la franja etaria relevada, no se presenta como una práctica tan preciada para el cuidado o el desarrollo de la salud en términos fisiológicos o anatómicos, más bien lo contrario. Desde una perspectiva más amplia e integradora, donde involucremos aspectos de bienestar y mejora en la calidad de vida a partir de los beneficios sociales que promueve en tanto percepción, comunicación e interacciones con otros, la práctica del fútbol entre padres se transforma en una opción saludable y sumamente valorada por ellos, los sujetos participantes.

\subsection{Representaciones}

Propongo conceptualizar las representaciones con el objetivo de establecer, tanto en el orden de lo real y de lo simbólico, aquellos elementos de la fantasía, la imaginación, los símbolos que los sujetos depositamos en las prácticas deportivas, cuáles son propias y cuáles conforman esa construcción de símbolos que pertenecen a la propia práctica y no a cada sujeto; cómo están naturalizadas y cómo son valorizadas por los protagonistas.

Las representaciones sociales son aquellas actitudes, creencias y discursos y manifestaciones que tratan sobre el conocimiento social del sentido común. Se aproximan a lo social considerando el contexto social y cultural del pensamiento y acción de los grupos intervinientes. Enfatiza la participación activa y creativa de los grupos en la interpretación de la realidad y en su construcción y cambio. La representación corresponde a un acto del pensamiento en la cual un sujeto se relaciona con un objeto, a través de operaciones mentales ese objeto es sustituido por un símbolo, el cual se hace presente ante la ausencia del objeto. 
En el proceso de representación las personas interpretan la realidad y en esa interpretación quedan plasmados sus valores, su posición política, religión, ideología, etc. Las representaciones circulan en el mundo, dan forma a nuestros modos de pensar y crean contenidos de pensamiento. No son exclusivas, ya que diferentes representaciones puede coexistir en una sociedad, son teorías o formas de pensamiento, de sentido común que permite a las personas interpretar y comprender su realidad, reorientar y justificar los comportamientos grupales.

La vida social, como actividad humana, no únicamente como categoría, incluye no sólo objetos y acontecimientos, sino acciones y manifestaciones significativas, de enunciados escritos o en actos de habla, de símbolos y artefactos de diversa índole; así como de sujetos que se comunican por medio de ellos para comprenderse a sí mismos y a los otros, a través de la interpretación de las expresiones que formulan y reciben. Una de las formas de comunicación que han acompañado a las personas en su evolución ha sido la construcción y uso de símbolos (Geertz; 1989; Thompson; 1998), quienes han constituido un lenguaje a través de los cuales se intercambien expresiones significativas. Los seres humanos no sólo recibimos estructuras del lenguaje significativas, sino que también otorgamos significado a construcciones no lingüísticas, como son las obras de arte, acciones o actitudes sociales y objetos diversos. Por ello, nos referimos al conjunto de la vida social como un "complejo simbólico cultural de las relaciones e interacciones sociales que le dan sentido y significado, a la vez que enmarcan la conducta social" (Fernando Osnaya Alarcón, 2004: 133-134).

Jodelet (1984: 478-480) plantea que las representaciones se presentan como una forma de conocimiento social, un saber del sentido común constituyéndose, en su opinión, en modalidades de pensamiento práctico orientado hacia la comunicación, la comprensión y el dominio del entorno. A su vez, propone cinco maneras para formular la construcción psicológica y social de una representación social. La primera se refiere a la actividad puramente cognitiva, con una dimensión de contexto y una de pertenencia. La segunda pone énfasis en los aspectos significantes de la actividad representativa, los actores laborales expresan el sentido que da su experiencia. Por consiguiente la representación es considerada la expresión de una sociedad determinada. Cuando es propia de sujetos que comparten una misma experiencia social, o una mismacondición social, la representación frecuentemente se relaciona con una dinámica que hace que intervenga lo imaginario. 
Un tercer elemento trata la representación como una forma de discurso y desprende sus características de la práctica. Sus propiedades provienen de la situación de comunicación, de la pertenencia de la finalidad de su discurso. El cuarto elemento hace referencia a la práctica laboral de los trabajadores, la cual está influenciada por el lugar que ocupan éstos en el proceso de trabajo. El quinto elemento plantea las relaciones intergrupales, las cuales determinan la dinámica de las representaciones.

Por ser las representaciones sociales mecanismos necesarios para el establecimiento de identidades colectivas y, por ende, para la coexistencia y estabilidad social, se les plantea cierta continuidad en el tiempo, sin que por ello se conviertan en nociones estáticas. Según Moscovici (1984), el concepto de representación social difiere del concepto de representación colectiva (tomado de Emile Durkheim) que puede ser visualizada en los mitos, la religión y las creencias de fe principalmente, en que el primero tiene un carácter más dinámico.

En opinión de este psicólogo social las representaciones sociales no son sólo productos mentales sino que son construcciones simbólicas que se crean y recrean en el curso de las interacciones sociales; no tienen un carácter estático ni determinan inexorablemente las representaciones individuales. Son definidas como maneras específicas de entender y comunicar la realidad e influyen a la vez que son determinadas por las personas a través de sus interacciones. Dos son los procesos a través de los cuales se generan las representaciones sociales. El primero es definido como anclaje y supone un proceso de categorización a través del cual clasificamos y damos un nombre a las cosas y a las personas. El segundo proceso es definido como objetivación y consiste en transformar entidades abstractas en algo concreto y material, los productos del pensamiento en realidades físicas; estos mecanismos, a través de los cuales se forman las representaciones sociales, sirven para la definición de los grupos sociales al tiempo que guían su acción.

Los discursos orales y escritos crean una imagen que tiene implicaciones sociales: transmiten y legitiman ideología y valores, mantienen y refuerzan el orden social, afianzan las diferencias sociales, construyen la identidad y, en definitiva, gracias a ellos, los hablantes y los oyentes creamos una representación de los acontecimientos, de las relaciones sociales y de nosotros mismos (Luis Cantero Abad: 145)

Entre las funciones que, según Morales (2007), cumplen las representaciones sociales, podemos destacar: a) que los individuos convierten una realidad extraña, desconocida, en una realidad familiar. b) permiten, además, la comunicación entre los 
individuos. La naturaleza simbólica y la construcción social de la realidad a partir de lenguaje con lleva representaciones sociales compartidas, contenidos cargados de significado. c) cuando las personas comparten significados sobre eventos y objetos existe la posibilidad de que se relacionen entre ellas. De modo que las representaciones sociales contribuyen a la formación, consolidación y diferenciación de grupos sociales. d) las representaciones sociales guían la acción social. A partir de la representación (que describe, clasifica y explica la realidad) los individuos definen las situaciones y así organizan y orientan su acción, definiendo la finalidad. e) así, las representaciones sociales sirven para justificar las decisiones, posiciones y conductas adoptadas ante un hecho.

Los autores nos brindan una definición en parte diferente de cada uno de ambos conceptos; mientras que en algunos casos se destaca la interdependencia entre ideologías y representaciones sociales, en otros, se acentúan sus diferencias al indicar que la ideología sirve para legitimar las creencias o el comportamiento de un grupo social mientras que las representaciones sirven para dar sentido y comprender la realidad social.

Las representaciones sociales de un objeto, del deporte por ejemplo en nuestro caso, pueden variar de un grupo a otro y esta variación tiene su origen en la complejidad social, en el complejo histórico y cultural de los grupos. El deporte es un ejercicio social que comparte similares valores pero que se ve sometido a diferentes significados según donde se juegue y quienes lo practiquen. "Podemos decir que las representaciones le dan sentido a las prácticas sociales, en este caso a las prácticas deportivas" (Solís, 2002).

La importancia que le atribuimos a estas representaciones en este análisis es que pueden guiarnos hacia el imaginario social con el cuál los sujetos realizan esta práctica particular del Fútbol para Padres, manifiestan sus deseos de protagonizarla, las dificultades con las que conviven, los bienes que persiguen y los valores que sustentan y cómo estas representaciones operan en los vínculos que se establecen entre ellos.

\subsection{Relaciones y Vínculos}

Analizar el concepto de relaciones y vínculos entre sujetos unidos por el bien común o un objetivo común que los reúne, pretende hallar situaciones de posicionamientos, liderazgos, roles y funciones, de cómo funciona lo grupal en su conjunto y las pequeñas sociedades o asociaciones circunstanciales. Pero además, el estudio pretende visibilizar cómo se producen estas relaciones y vínculos en torno a la práctica del fútbol entre 
padres, cómo derivan hacia otras dimensiones de la vida social y cómo la práctica misma se constituye en un ordenador y operador de estas configuraciones relacionales.

La vida de todos los seres vivos está condicionada por diversas formas de relación y múltiples variedades de las mismas, en relación al hábitat y medio ambiente entre las especies animales y en el caso de las personas, debemos agregar a las costumbres y culturas.

Las relaciones humanas es el nombre que se le da al conjunto de interacciones entre los individuos de una sociedad, bajo diferentes órdenes y formas de comunicación. Estas relaciones interpersonales pueden darse en una gran variedad de contextos: familiares, laborales, religiosos, amistades, etc. La condición humana de ser social, hace que las relaciones humanas sean una constante búsqueda del disfrute de relaciones armónicas con el otro, sustentadas en el respeto, la comprensión, la cooperación y la comunicación, pretenden, a pesar de las diferencias lógicas entre las personas, lograr una atmósfera de cordialidad, comprensión y sincero interés por el bien común. Pueden estar reguladas y sostenidas por la ley, el afecto, la costumbre y los acuerdos. Y por la combinación de ellos también, porque veremos que de algún modo es lo que ocurre con el caso de estudio.

La palabra vínculo, etimológicamente proviene del latín, vinculum y significa unión, lazo, atadura, sujeción, relación entre dos cosas, personas o animales. Pueden ser de índole material (negocios, bienes); profesional (médico-paciente; abogado -cliente; maestro-alumno); espiritual (amistades, religión) o sanguíneos (miembros de una familia). Algunos son voluntarios y otros impuestos por la naturaleza o por la Ley.

La noción de vínculo suele utilizarse para nombrar una especie de cadena invisible, insustancial que existe entre dos personas. Suele emparentarse con un tipo de relación más íntima y profunda que una ocasional, temporaria o circunstancial. Esta característica estaría mediada por el afecto. Es el sentimiento amoroso que se siente por otras personas, el placer de tenerlo cerca, tener contacto físico con ella, compartir momentos, situaciones y otro tipo de eventos los que son ampliamente estimulantes, nos acercan y fortalecen este tipo de relación.

A su vez, por estar atravesados por las emociones y sentimientos, los vínculos son sumamente sensibles a las alteraciones de humor, manifestaciones, palabras y actos de las personas que las participan. Por ello es que por lo general, se desarrollan vínculos 
más certeros y duraderos con personas afines en gustos, ideas, conceptos, fe y percepciones generales de la propia vida. El placer y bienestar resultantes de la compañía del otro, refuerza nuestra necesidad de repetir el encuentro y el contacto. Al ser este recíproco, es decir, que la otra persona sienta lo mismo o en circunstancias y valores semejantes al propio sentimiento compartido, la necesidad se multiplica.

Es así como la conformación espontánea de grupos de personas que se unen para un objetivo en común, es uno de los escenarios más positivos para el desarrollo de vínculos duraderos y genuinos, ya que el mismo objetivo, unifica ideas, prioridades y gustos. Sublimar objetivos personales en busca del bien común es uno de los principales valores que propician la formación de grupos, cualquiera sea el objetivo que los congrega. La conformación de los grupos sociales está fuertemente arraigada a las formas de comportamiento objetivadas en normas, valores y objetivos compartidos, acordados y necesarios para el buen funcionamiento del grupo. Es en este escenario como confluyen ideas, sentimientos, intenciones para construir entre todos una práctica organizada, frecuente y sistemática, sostenida en el tiempo en virtud de la recuperación del espacio lúdico, la competencia deportiva entendida en la búsqueda de los bienes intrínsecos del juego, el respeto por las reglas y la posibilidad de encontrar en el otro, no solo un rival o adversario ocasional, sino a otro par, a otro igual.

Será necesaria además una distintiva identidad y un sentido o sentimiento de pertenencia que lo posicione como rasgo particular de sus ideales o sentido. La identidad es una búsqueda de toda la vida, el esfuerzo por encontrar un sentido de sí mismo y del mundo es un proceso sano y vital que contribuye a la fuerza del ego del adulto. Estimula el crecimiento y desarrollo de los sujetos y del grupo y ayuda a alcanzar un adecuado nivel de autoestima. Necesita además, de la resolución de roles recíprocos dentro de sus participantes, y el encumbramiento de alguna forma de liderazgo que los movilice a la obtención de los objetivos propuestos. (Erikson, 1974)

Los tipos de relaciones y vínculos que se desarrollan en el caso estudiado ponen su centralidad en la constitución y afianzamiento de los grupos a través del tiempo por los fuertes lazos construidos sustentados en los objetivos en común, el gusto por la misma práctica deportiva, el respeto, la búsqueda de los bienes intrínsecos del deporte, la visión compartida de los procesos de representación y simbolización en el deporte, la amistad y la camaradería. Estos aspectos serán desarrollados en los próximos capítulos a la luz de las evidencias recogidas del trabajo de campo y los textos analizados. 


\section{CAPITULO II}

\section{Capitulo II - El trabajo de campo.}

\subsection{Metodología y herramientas}

La toma de datos se realizó directamente en los campos de juego, los días domingo por la mañana en los tres horarios en que se fijan las competencias: 9:00 horas, 10:30 horas y 12:00 horas durante la temporada de juegos del año 2013.

La visita metódica a las tres sedes en que se realiza el Torneo ${ }^{10}$ garantiza que en el período descripto todos los participantes pudieron participar de las encuestas y / o las entrevistas. El acceso a las sedes y canchas es sencillo, distan entre unas 15 a 20 cuadras entre sí y puede accederse con vehículo propio.

Los encuestados y entrevistados fueron invitados a participar a lo largo del Torneo del año 2013 en los momentos previos a la competencia. Se dispuso de sillas, mesas, tablas de apoyo, lapiceras, etc. para la comodidad de los participantes. La encuesta consistió en un cuestionario de 20 preguntas de carácter mixto, (de respuestas abiertas y cerradas), que los participantes respondieron en los momentos previos al partido, cuando se acercaban a los distintos campos de juego.

Tanto la organización como los delegados y capitanes de los equipos manifestaron su conformidad, interés y facilitaron la participación de los jugadores. Todos estuvieron informados y avisados de los objetivos e intereses de la investigación mediante una presentación previa a la organización, con los capitanes y delegados de los equipos presentes.

Los encuestados y entrevistados manifestaron su agrado por colaborar y participar de la instancia y resaltaron el valor y utilidad de los datos preguntados. La condición de que el investigador sea para ellos una persona conocida, en calidad de jugador participante del Torneo desde hace tantos años, facilitó la realización del trabajo de campo, mostrando en ellos predisposición y entusiasmo.

Las entrevistas también se realizaron en los campos de juego, por lo general en los tiempos de espera a jugar el partido, antes que los jugadores comiencen a cambiarse o bien a aquellos que asistieron al partido y por alguna circunstancia no podían jugar ese día. Traté de incluir preguntas no formuladas en los cuestionarios, dejé que los

\footnotetext{
${ }^{10}$ Ver Anexo respecto a los mapas del sitio donde se desarrolla el Torneo.
} 
entrevistados lleven la conversación hacia lugares no esperados ni inducidos, para apreciar que otras cosas aparecían en sus discursos, más allá de responder a algunas preguntas comunes. Las entrevistas se registraron a través de una aplicación del teléfono celular, luego se hizo la reproducción y transcripción de las mismas y se recuperaron los pasajes más trascendentes a mi interpretación, contextualizando el relato a los intereses de este estudio.

Las observaciones y anotaciones de campo ocurrieron a largo de todas las jornadas, en las diferentes canchas procurando alcanzar a la totalidad de equipos participantes. Algunos equipos fueron registrados en más oportunidades debido a la rotación de fechas y partidos. Se describen en las mismas, comportamientos, actitudes, palabras o frases muy utilizadas, que resultan ponderables por su reiteración, frecuencia y continuidad en la mayoría de los equipos. También a través de estas observaciones y anotaciones se relevaron aspectos importantes que no podrían verse vinculados solo a través de las encuestas y entrevistas, cómo hábitos de concurrencia, interacciones entre compañeros y adversarios de turno, distintos tipos de expresiones, manifestaciones y testimonios que contribuyen a representar, al menos en mi interpretación, algunos rasgos comunes, que terminan por definir y caracterizar ésta práctica.

\subsection{Análisis de los datos}

\section{Resumen final de los datos estadísticos:}

\begin{tabular}{|c|c|c|c|c|c|c|c|c|c|c|c|c|c|c|c|c|c|c|c|c|c|c|c|c|c|c|c|c|c|c|}
\hline & & ED & AD & & & $\|$ & & & & & & & & MOTIV & VACIONE! & & & REPRESE & ENTACIO & & & & & & & RENDIZ & & & líNC & ULOS \\
\hline & & & & & (1) & is & & & & 1 & & & & & An- & D & $a_{0}$ & & Diven & & Chequ & $180 \mathrm{En}$ & & & Juege & & Regaglas & & 1 poyo & Cambios \\
\hline & & & & & & 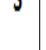 & & 0 & 1 & 6 & $\sqrt{2}$ & 4 & & & & thy & & & & & & No & Si & No & $\mathrm{Si}$ & No & \begin{tabular}{l|l} 
Si & No
\end{tabular} & 0 & No & Si \\
\hline & 66 & 107 & 90 & 106 & 20 & 154 & I & 12.2 & 69 & $1 / 0$ & 95 & 69 & 168 & 69 & 177 & 228 & 111 & 258 & 197 & 161 & 243 & 126 & 156 & 213 & 245 & & 64205 & & 326 & \begin{tabular}{|l|l|l}
196 & 17
\end{tabular} \\
\hline OFEVITIE & $180 \%$ & $29 \%$ & 24\% & $29 \%$ & & $\Delta \%$ & 100/ & & 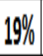 & & & & $46 \%$ & $19 \%$ & $48 \%$ & $62 \%$ & $30 \%$ & $70 \%$ & $53 \%$ & $44 \%$ & & & $42 \%$ & $58 \%$ & & $40 \% 4$ & $4 \%(56 \%)$ & & $\% 7 \%$ & $53 \%$ \\
\hline
\end{tabular}

Desglosados de los datos recabados a través de las encuestas realizadas; un total de 369 que representan un $65.9 \%$ de los jugadores participantes del Torneo de fútbol para Padres (al momento de esta investigación, diciembre de 2013), se hallan los siguientes resultados: 


\section{Configuración social}

El primer análisis refiere a caracterizar el contexto socio cultural y económico de los sujetos protagonistas del estudio. Así, a través de las encuestas se recabaron datos de edad, estudios alcanzados, ocupación, conformación de la unidad familiar, colegio al que asisten los hijos, etc.; dando por hecho y siendo requisito para la participación ser padre de alumnos escolarizados en las escuelas participantes y por tanto hombres, masculinos.

En relación a la edad de los participantes, se encuentra una distribución bastante pareja, siendo mayoritaria en la franja de 35 a 40 años y en los mayores de 45, cuando en principio se sospechaba que la edad mayoritaria era entre los 40 y 45 años y los más jóvenes de más de 30 .

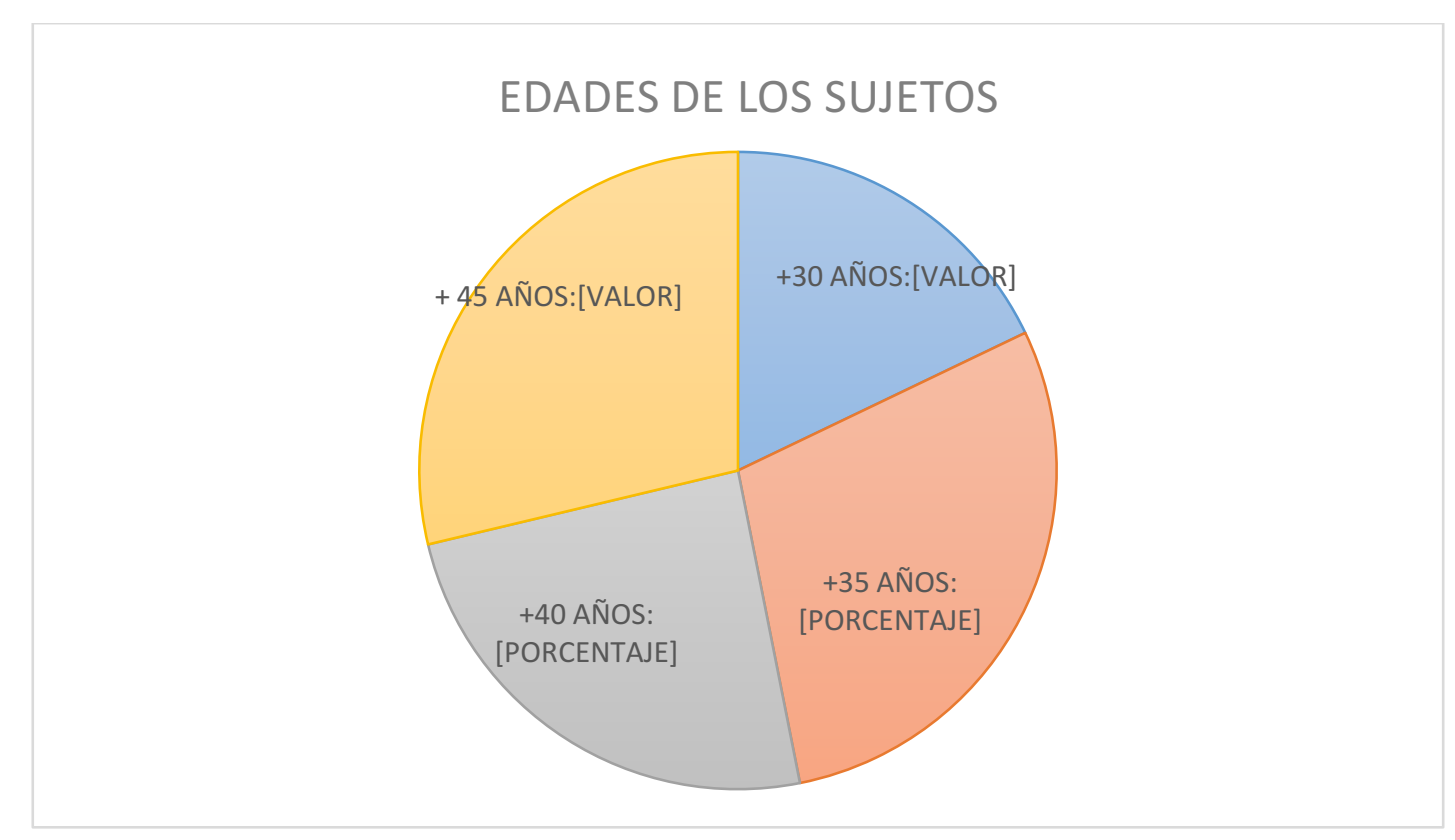

Este dato se puede emparentar con la cantidad de años en que los equipos permanecen en esta competencia como equipos conformados. Es decir, el porcentaje mayoritario de padres de + de 45 años corresponde en buena medida a aquellos padres que hace más de 10 años que continúan en esta práctica, siendo de los jugadores participantes del Torneo original. El grupo de + de 35 años son los más participativos activamente en los equipos y forman parte preferentemente de los nuevos equipos incorporados al Torneo. Los sujetos de + de 40 y + de 30 años se distribuyen en forma 
pareja entre todos los equipos; siendo bastante lógica la proporción menor en los mayores de 30 , ya que el torneo de por sí propone límite de edad inferior ${ }^{11}$.

En cuanto a los estudios completos alcanzados por los participantes, (en el cuadro de resumen se categorizan como P: Nivel Primario; S: Nivel Secundario; T: Nivel Terciario No Universitario y U: Nivel Universitario) se advierte que la mayoría alcanzó a terminar la escolarización secundaria y en segundo lugar, los de grado universitario. Es muy menor, el porcentaje de padres que alcanzaron solo la escolarización primaria.

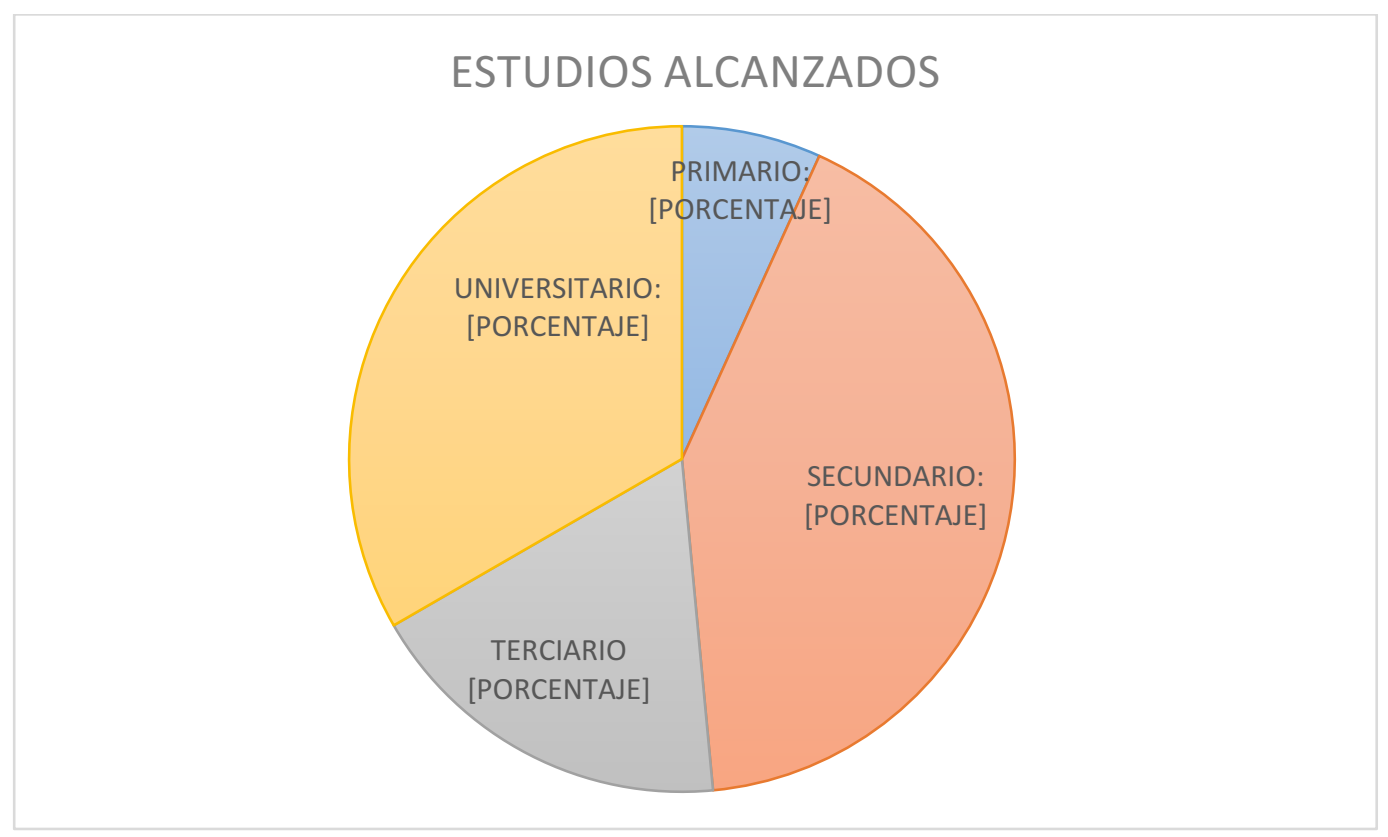

El dato es relevante en cuanto complementa el estrato o nivel sociocultural y económico del que se compone el universo de sujetos encuestados. Los que obtuvieron titulación universitaria y ejercen su profesión representan un tercio de la población encuestada; los de nivel terciario son en su mayoría docentes o de titulaciones alternativas gastronómicas, informáticas, etc. La mayoría de los que alcanzaron estudios secundarios se desempeñan como comerciantes, dueños de su propio negocio, pocos bajo relación de dependencia o bien como empleados en el sector público o privado. Se registran casos de trabajadores por cuenta propia, albañiles, técnicos, plomeros, gasistas, herreros y empleados en servicios públicos y privados entre los sujetos con alfabetización

\footnotetext{
${ }^{11}$ Ver anexo Reglamento del Torneo de Futbol para padres Virgen Niña.
} 
primaria. No se registran desempleados, ni personas sostenidas por planes sociales 0 subsidios del Estado.

El $48 \%$ de los encuestados manifiesta poseer una familia tipo, conformada por mujer o esposa, más dos hijos. En este sentido, tal vez es más importante destacar el dato de quienes tienen 3 o más hijos, conformando familias numerosas, es decir un $45 \%$ de la población encuestada. Las más tradicionales familias de la zona de Bella Vista solían ser de muy prolíferas en hijos, conformando familias sumamente numerosas al relacionarse solo entre ellas, conservando una condición social sólida entre sus mismas relaciones sociales, por distintas generaciones.

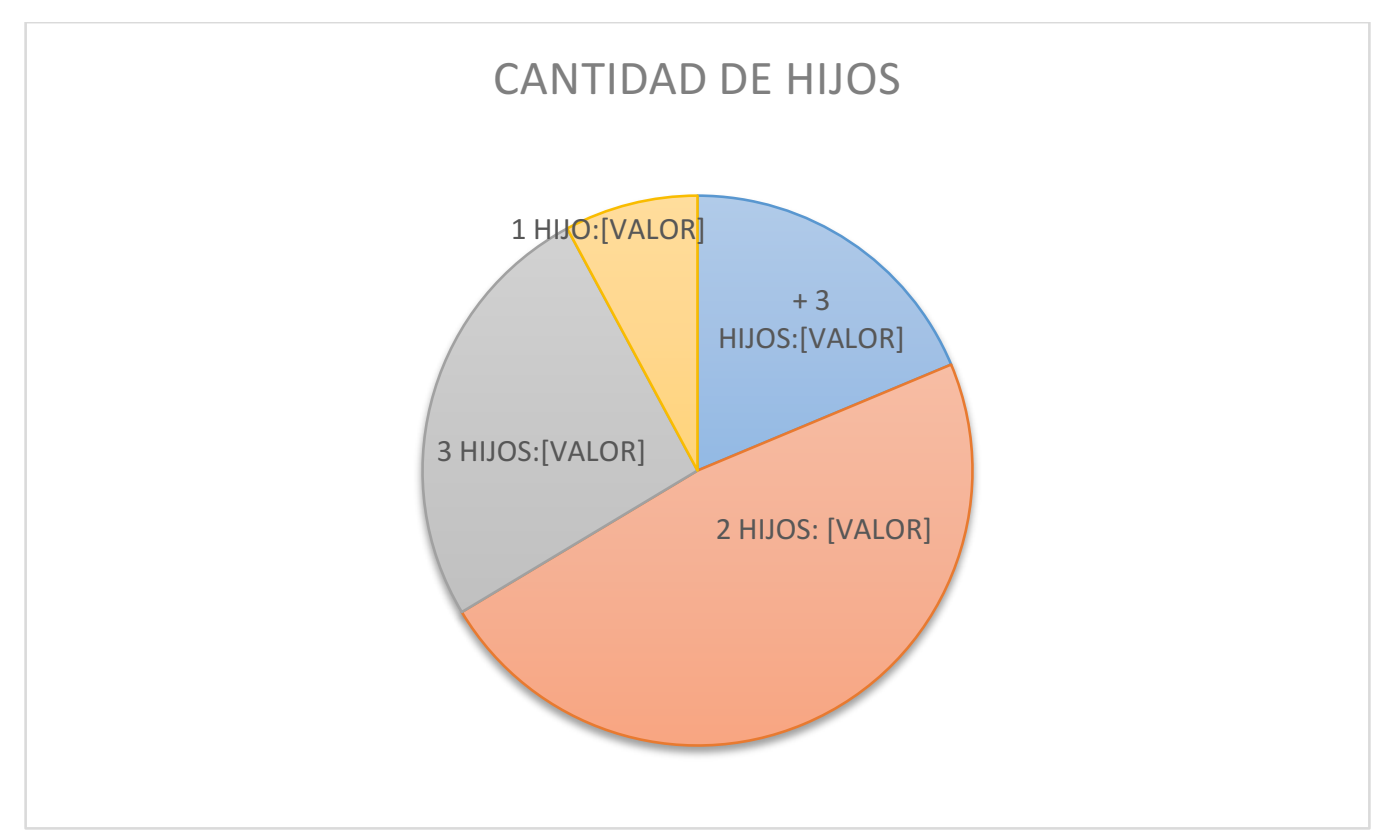

Un dato no encuestado pero que se desprende de la nómina de los Colegios participantes, es que todos pertenecen al ámbito privado, no hay Escuelas Públicas (y por lo tanto padres participantes) inscriptas en el Torneo.

No todas las escuelas privadas a las que se hace referencia poseen subvenciones del Estado, por tanto los valores de las matrículas de inscripción de alumnos y cuotas por el servicio escolar son variables entre cada una. De todas maneras, se puede establecer 
un amplio margen de valores al respecto, (entre $\$ 800$ y $\$ 6500$ actuales) entendiendo que representan valores medios y medios-altos para la zona de influencia.

Un dato proveniente de la observación de campo que puede ayudar a establecer cierta correspondencia con la clase social de pertenencia es que la enorme mayoría de los participantes acude a los encuentros en su propio vehículo. Muy pocos llegan en grupo, y si lo hacen por lo general es a bordo de camionetas y $4 \times 4$. No se observan vehículos viejos, averiados, etc.; lo que permite pensar en la posibilidad de la renovación frecuente y el salto de calidad de los mismos.

Otro dato relevado de la observación y de las anotaciones de campo, sobre todo en las últimas temporadas, es el de la aparición de tecnología de última generación (smartphones, tablets,) que reemplazaron a las cámaras de fotos y video filmadoras para registrar los momentos preciados; así también el uso de auriculares y mp3 y 4 que son utilizados para amenizar las sesiones de calentamiento, sobre todo por los participantes más jóvenes.

El uso de heladeras y conservadoras para la hidratación con bebidas isotónicas (Gatorade, Powerade y similares) y para continuar compartiendo en un tercer tiempo luego del partido (gaseosas de primera marca, cervezas y fernet), superan el uso común de los bidones de agua, para calmar la sed.

Finalmente, también se aprecia una evolución en la calidad de la indumentaria y calzado con la que son provistos los equipos. Al comienzo eran camisetas que algún miembro del grupo tenía, luego pasaron a juegos de camisetas de equipos y selecciones de fútbol conocidas (nacionales y extranjeras) y hoy son camisetas de diseño propio, conjuntos completos incluyendo pantalones y medias; respetando colores y logos de los Colegios representados y hasta con sponsorizaciones muy visibles. En cuanto al calzado, quienes habían desempolvado sus viejos botines negros en desuso, pasaron rápidamente a la elección de los innumerables modelos y diseños de colores que abundan el mercado de las tiendas deportivas.

Los datos asociados demuestran algunos aspectos que la clase social a la que pertenece la población estudiada; a la que a simple vista, puede clasificarse como media - media alta en nuestros estándares sociales. 


\section{Motivaciones}

Otro dato sobresaliente que me interesó indagar, fue acerca de las diferentes causas que movilizaban a los jugadores a participar de este torneo; por qué la elección de éste Torneo y no de otros posibles. Para la categoría motivaciones, entendido este término por las ganas, los intereses, los deseos, las intenciones que movilizan a estos hombres a reunirse para jugar al fútbol, manifestaron:

Reuní en Ganas / Diversión a aquellas respuestas asociadas a términos o definiciones como "porque me gusta", "para pasarla bien", "por la pasión por el deporte", etc.

Por Salud, a aquellas representadas en frases como: "para hacer actividad física", "para mantenerme en forma", "por hacer algo de ejercicio", "para correr un poco", etc.

En Amistad a aquellas expresadas como: "por el grupo de amigos", "por el compañerismo", "por la camaradería", "porque se formó un lindo grupo" etc. Y en Deporte, a aquellas respuestas como: "por deporte", "porque me gusta el fútbol", "porque siempre jugué al fútbol", etc.

Muchos de los encuestados eligieron múltiples razones, por ello en este caso, los resultados son nominales y no absolutos en términos de porcentajes. El deporte, por caso la categoría más elegida, por lo que considero importante hacer un análisis más profundo sobre este concepto en tanto elección por parte de estos sujetos para la ocupación de su tiempo libre, y a las percepciones y representaciones depositadas en su práctica.

El $61.8 \%$ de los encuestados eligió el Deporte como principal motivacional para la participación en este Torneo. Algunas frases recuperadas de las entrevistas ilustran esta cuestión:

- "Yo siempre jugué al fútbol, siempre me gustó"

- "No hay nada como ponerse los cortos y correr atrás de una pelota"

- "Iba a dejar, ipero es más fuerte que yo!... El fútbol es una pasión!" 


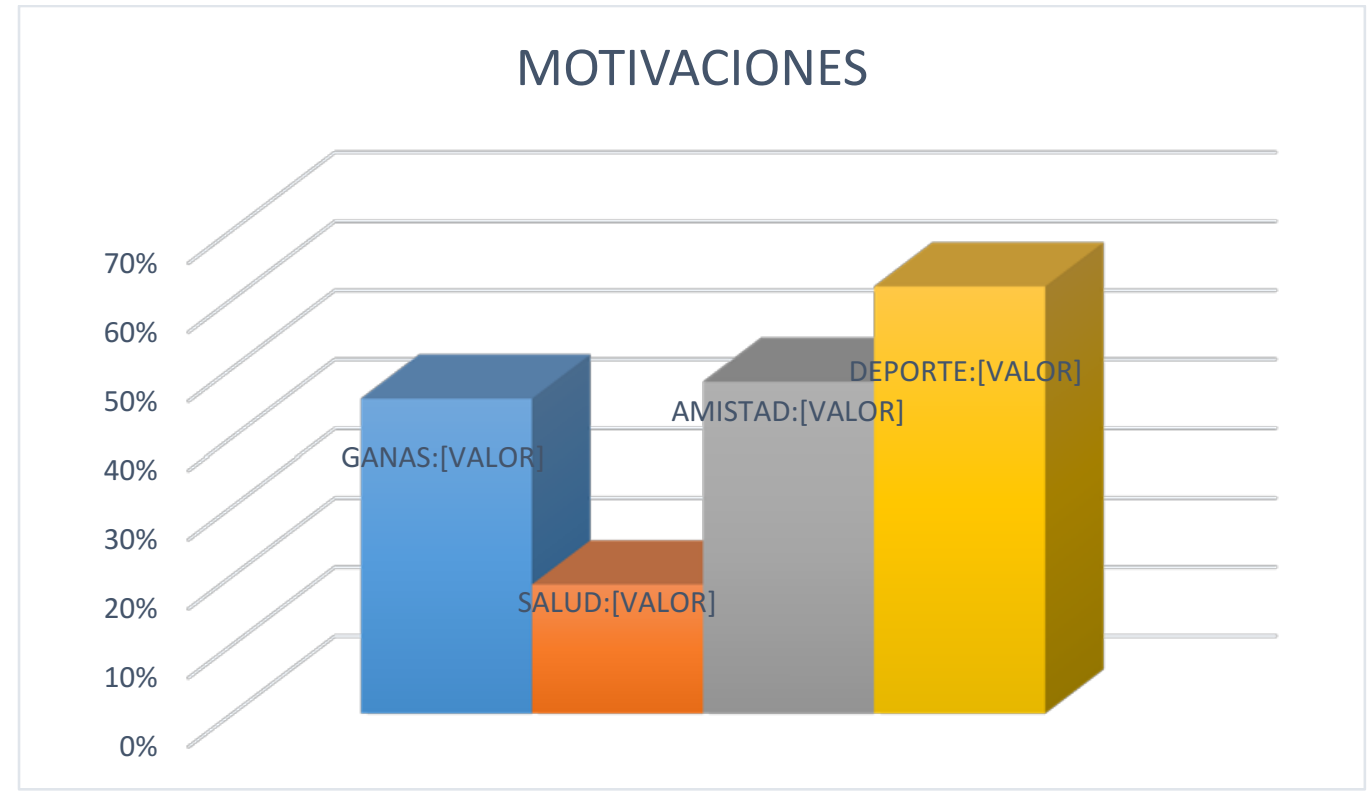

El $47.9 \%$ también considero a la Amistad como uno de los factores que los mueven a la participación. Apenas por debajo, con un 46\% de aceptación se registran las Ganas y este es un dato muy importante porque la intencionalidad en la recuperación del espacio lúdico y la utilización del tiempo libre en las prácticas deportivas en estos adultos es un dato a interpretar con más profundidad en el próximo capítulo.

De las entrevistas realizadas se refuerza el aspecto social del encuentro deportivo de cada domingo, dando cuenta sobre todo del valor puesto en el sentido de pertenencia al equipo, lo importante de encontrar un grupo de amigos y de conocer nuevas personas a partir de la participación en el Torneo. La amistad, la camaradería, el momento de placer de compartir con amigos, hacen de este espacio un lugar difícil de dejar.

-“lo más importante es el grupo de amigos que se formó”

-"yo vengo por el grupo"

-"estoy lesionado (o suspendido), pero vengo a hacerle el aguante al equipo"

Las relaciones trazadas a partir del encuentro deportivo continúan a lo largo de la semana, los días y los meses. Deja de ser un encuentro casual y esporádico, aleatorio y distante, para constituirse en parte central de las relaciones personales de los participantes. Como será también analizado en el capítulo III, la idea de equipo, de grupo y de identidad es clave para comprender las configuraciones y el tipo de relaciones que se establecen entre estos adultos. 


\section{Las representaciones}

En cuanto a la concepción del Deporte es muy amplia y variada en cada uno de los participantes, la lucha por el espacio lúdico y recreativo del juego contra la pulsión por la victoria, el triunfo y el vencer está muy presente. Lo que llevó a preguntar, tanto en las entrevistas como en las encuestas acerca de las representaciones, acerca de lo que era importante en el encuentro deportivo de cada domingo.

Agrupé en Ganar a aquellas respuestas donde el resultado es lo más importante y en Jugar a las que eran relativamente importante o no eran importantes; y por otro lado pregunté si tenían pensamientos o no pensaban en los partidos jugados o por jugarse.

Me resultó llamativo el manifiesto interés por jugar más que por ganar, la relación de $70 \%$ a $30 \%$ entre ambas así lo demuestra. Sin embargo a la respuesta por los pensamientos durante la semana estaban más vinculadas a mejorar, corregir errores, analizar los defectos del rival, etc., asociadas más al resultado del partido.

Otros casos, (bastantes menos) tenían recuerdos sobre situaciones graciosas o momentos agradables ocurridos durante el juego. Hay reincidencias y nuevas comunicaciones durante la semana a través de mails, chats, fotos, videos y whatsapp sobre estas situaciones.

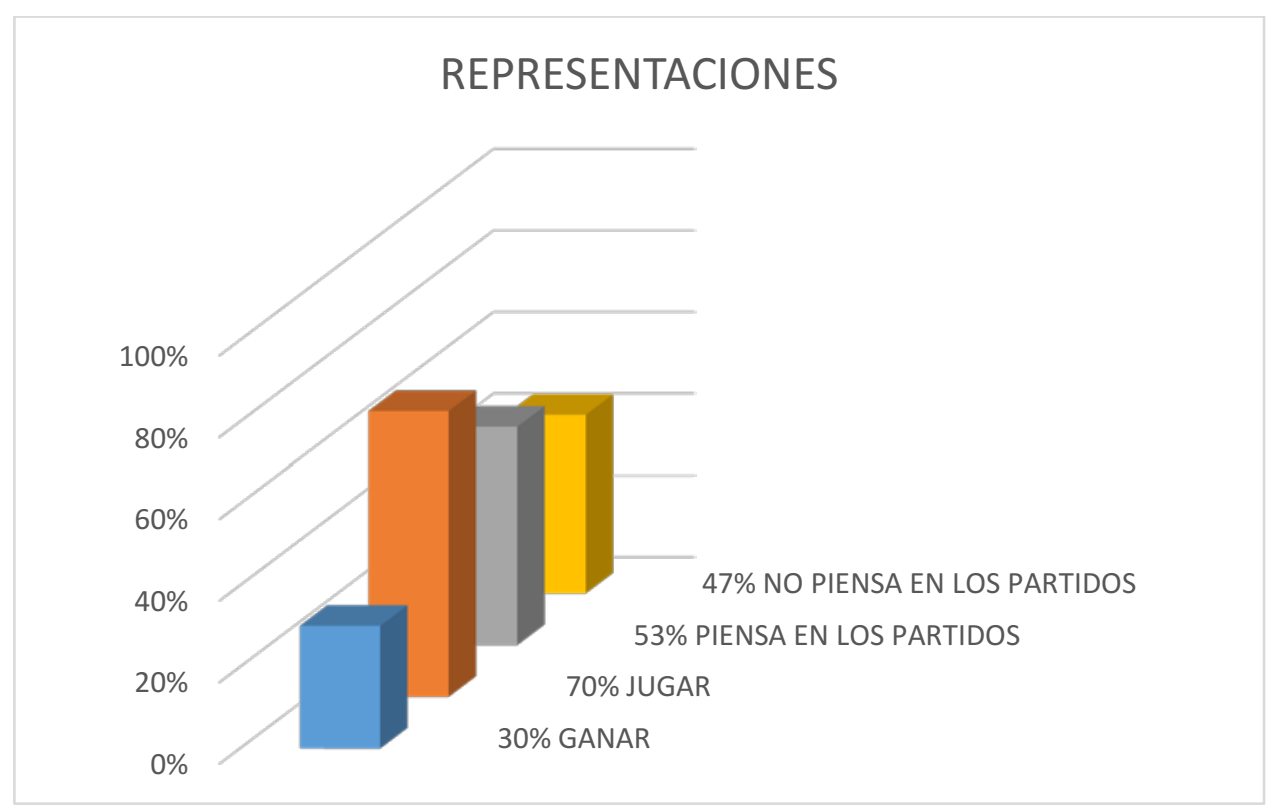


Las anotaciones de campo y observaciones dan cuenta que el interés por ganar está muy de manifiesto, sobre todo hacia los finales de la temporada donde la lucha por el campeonato o por el descenso de las categoría, hace que los partidos tengan una intensidad mayor. Los equipos que no juegan por ninguna de la circunstancias extremas, aquellos que no tienen chances de salir campeón y que tampoco corren riesgos por perder la categoría, son los menos, y esta situación los relaja un poco de la presión de la competencia y pueden jugar más aliviados y recuperar el aspecto lúdico del juego.

Desde el posicionamiento más externo y objetivo de la observación, también puede apreciarse como lo viven los que están fuera del campo, los suplentes, los que esperan por ingresar y los que ya fueron sustituidos. Aquí también las manifestaciones son disímiles, pasando de las arengas de apoyo y aliento a los compañeros a los insultos a propios, adversarios y jueces, de aquellos que evidentemente participan por ganar en la competencia deportiva.

También están aquellos que viven con mucha ansiedad la espera por su participación. No les preocupa tanto como es el resultado del partido, sino cuánto falta para que sea su turno de jugar. Seguramente la carga personal acerca del propio rendimiento más que el del equipo, tiene más relevancia para él. La principal preocupación pasa por evaluar muy críticamente su desempeño en el partido, si dio buenos pases, si cometió muchos errores, si se perdió algún gol, si corrió más o menos que la semana pasada; y por otro lado la fantasía de cómo hubiera resuelto mejor una situación del juego si él hubiera sido el protagonista, y no un compañero como ocurrió en realidad, son los principales argumentos y pensamientos que rondan en la imaginación de los jugadores.

Desde la observación participante, también podemos decir que aflora en todos los equipos, el rol y el protagonista (uno o varios) de esa necesidad por conducir y decir qué es lo que se debe hacer, cómo se debe jugar, a quién del otro equipo hay que marcar, y hasta quienes deben jugar y quienes deben salir del propio equipo. Esta suerte de Director Técnico de fútbol que todos los apasionados por este deporte llevamos dentro. En algunos es solo pasajero y su opinión emerge a partir de las circunstancias del partido mismo, en caliente; en otros, estas ideas dan vueltas en la mente durante la semana, son los que piensan en los partidos. 
En cuanto a los pensamientos durante la semana acerca de los partidos realizados o los que están por disputarse próximamente, las entrevistas ratifican lo evidenciado por las encuestas. Es relativa la importancia brindada a los juegos, si bien hay algunos preocupados por como corregir errores y plantear nuevas estrategias propias para los próximos partidos. Existen algunas bromas y comentarios divertidos a través de las redes sociales y grupos de comunicación interna de cada grupo, a los cuales no he tenido acceso, más que los dichos de los protagonistas.

Sí se plantea, cierta ansiedad por la llegada del día domingo cuando éste se acerca en el trayecto de la semana, y se evidencia la preocupación por los factores climáticos, dado que una imprevista lluvia pueda suspender la fecha.

-"ojalá que no llueva el próximo domingo"

-“ique bajón! El próximo finde es largo y no hay fecha! “

" $¡ Y$ Ya van dos fechas suspendidas por lluvia! Tengo unas ganas de jugar que me muero!"

Son algunas de las expresiones más escuchadas cuando suceden éstas circunstancias que obligan a la suspensión de la fecha.

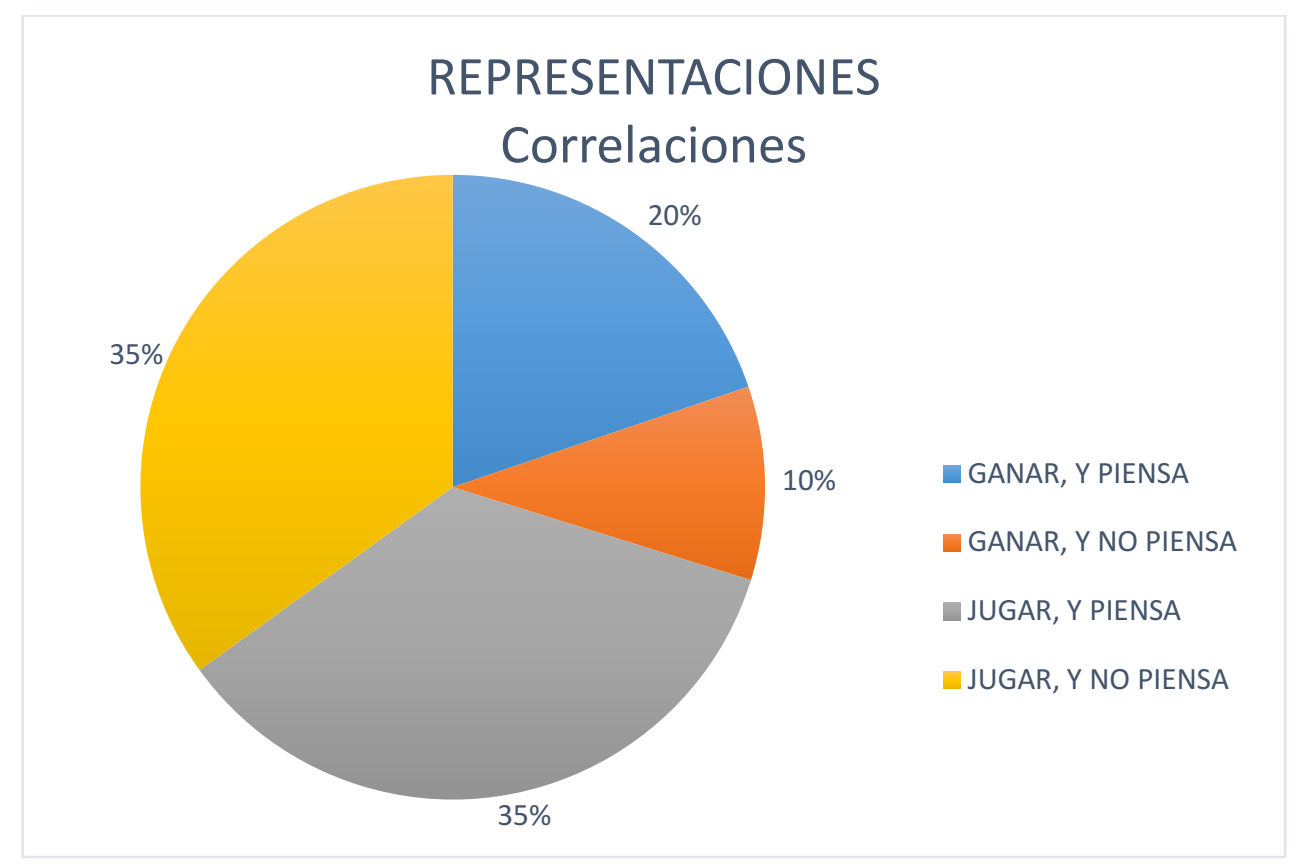


Un análisis más profundo en virtud de las contradicciones encontradas entre los que dicen que no piensan en los partidos y que es más importante jugar que ganar, demuestra que solo un $10 \%$ de los encuestados quiere ganar pero no tiene pensamientos en relación a los juegos durante la semana. Es decir que solo quiere ganar en el momento de jugar el partido los domingos. No tiene representaciones ni significantes importantes depositados en el Torneo más que las ganas de ganar el día del partido.

Casi la mitad de los encuestados (45\%) dice tener pensamientos durante la semana relacionados a como jugar, mejorar, aprovechar los defectos del rival y anular sus virtudes. Es decir, propone supuestos, acciones posibles y anticipatorias en relación al futuro partido por jugarse. Otra porción importante, más de un tercio de los encuestados dice simplemente venir a jugar, que es un pasatiempo y que no ocupa su mente en la semana con situaciones del partido o de los próximos.

-"esto es un distracción, sino sería un quilombo más"

-"no, yo vengo a jugar nada más...que se preocupe el técnico de los partidos"

Otro tanto puede decirse de la revisión de las propias acciones, jugadas y posibles desenlaces si pudieran haber resuelto de otra manera, las pasadas prácticas. Es decir, la revisión crítica de la propia práctica realizada. La confrontación entre los hechos reales y los supuestos probables constituyen una manera de referenciar los significantes que la propia práctica tiene. La intencionalidad de los jugadores en esta revisión es lo que los diferencia en su análisis por disfrutar en forma diferente de esta práctica o en la necesidad de mejorar y ganar en el próximo partido.

Quienes dicen relativizar el valor de ganar en los partidos en disputa, o destacan no transformar el momento del disfrute del juego en una obligación o responsabilidad más, se acercan a la idea de la recuperación del espacio lúdico como una necesidad del adulto; mientras que a quienes les preocupa la idea de ganar, el resultado, la tabla de posiciones, están más cerca de la posición que impulsa a la participación en sistemas organizados de competencia con objetivos en la retribución de premios o jerarquías, tema que será profundizado en el capítulo siguiente. 


\section{La idea de salud}

Con relación al concepto de salud me interesó constatar si los jugadores se realizaban o no chequeos médicos y si los sujetos se entrenaban o no a los efectos de la participación en el Torneo. Si bien 2/3 de los encuestados se han realizado estudios médicos, antes o durante el torneo, muy pocos entrenan o lo hacen una sola vez a la semana en función del torneo.

Algunos realizan actividad física extra, gimnasio, natación, paseos en bicicleta, caminata por el corredor aeróbico, pero no deben asociarse a la práctica del fútbol. Algunos equipos se encuentran una vez a la semana para jugar al fútbol, pero en realidad la asistencia de ninguna manera es obligatoria ni condiciona la participación en los partidos del día domingo.

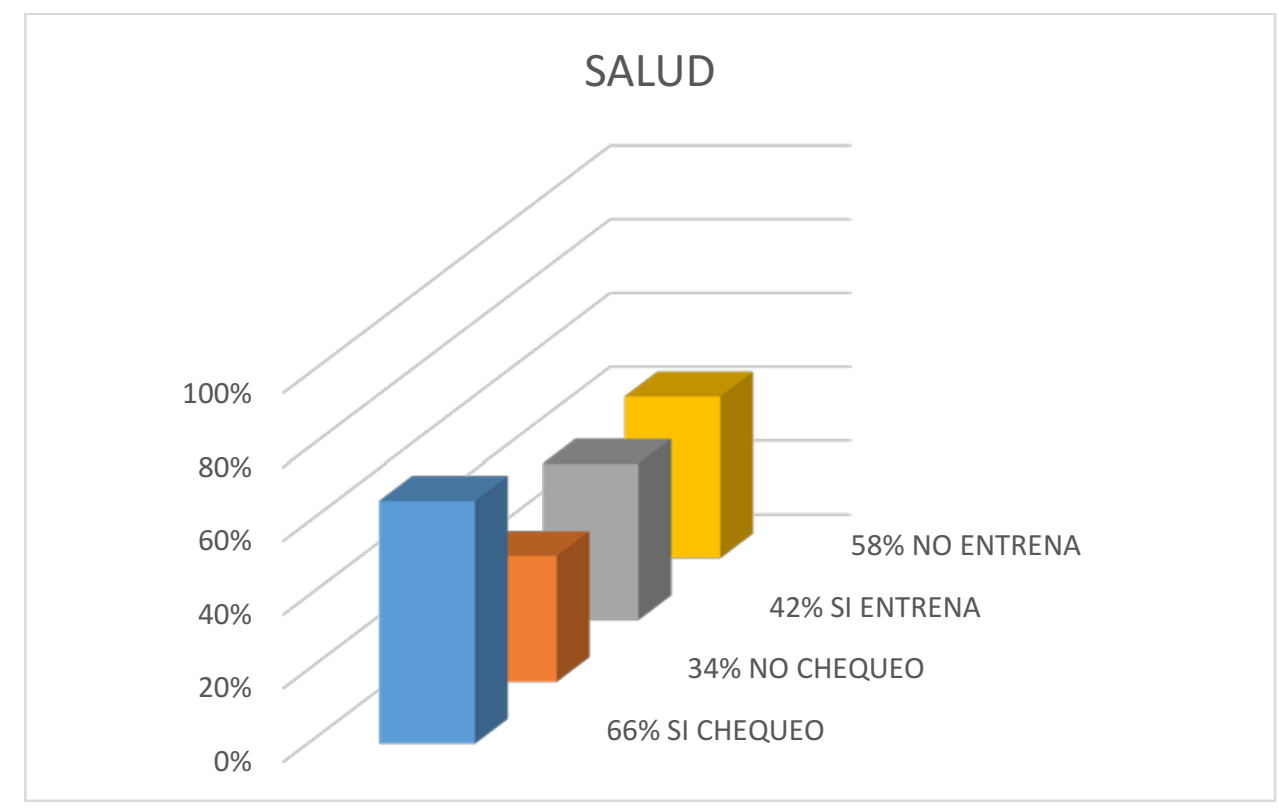

En las entrevistas se refuerza que la acción del "entrenamiento" semanal, pasa más por el encuentro social para quedarse a "picar algo" (pizzas, asado, picadas, etc.) que por el acondicionamiento físico pro torneo. En realidad es casi una excusa para volver a reunirse. Lo más importante no pasa por la práctica deportiva, sino por el nuevo encuentro con el grupo. 
También fue la causa, razón o motivación menos elegida a la hora de esta indagación. Existe un discurso correcto sobre esto, lo que está bien decir, "hago actividad física porque es bueno para la salud", para "sentirme mejor", porque "hace bien". Lo evidente es apreciar sujetos con exceso de peso, sin entrenamiento, que más parecieran padecer la situación deportiva (al menos fisiológicamente), agitados, con síntomas de dificultades respiratorias y cardíacas. Son comunes las lesiones de esguinces de tobillo y rodilla de moderados a serios, algunos que han terminado en intervenciones quirúrgicas, rehabilitaciones prolongadas y... reincidencias a ésta práctica deportiva y social.

Aquellos que realizaron chequeos médicos de control, no necesariamente consultaron con su médico acerca de éste tipo de práctica deportiva.

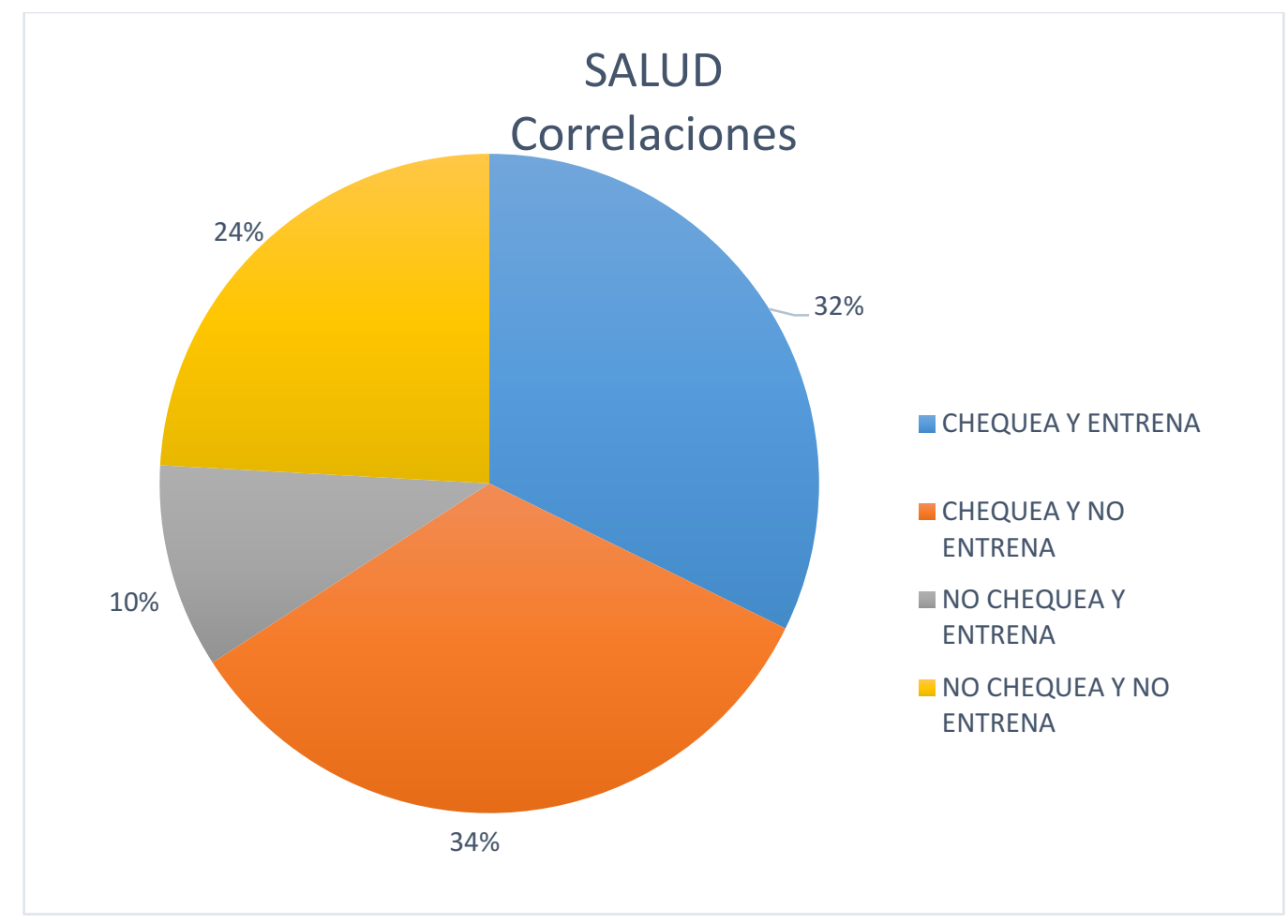

Resulta preocupante como dato duro, que casi la cuarta parte de los sujetos participantes no se haya evaluado ni consultado previamente a un profesional en tanto participa de una actividad competitiva; por el grado de estudios alcanzados por los sujetos, se estima que no puede ser por falta de información. 
-“No, con lo que fumo y chupo, si le digo al médico que juego al fútbol me mata!".

-"Hoy limpio todo lo que chupé ayer!; ..."Hoy no me muevo, ayer comí como una vaca!"

-“y qué querés,... ayer salí y tengo 2 horas de sueño...de pedo que vine a jugar para no fallarles".

Comentarios de este tipo son frecuentes y relevados tanto en las entrevistas como en las observaciones de campo, que dejan en evidencia a los participantes en cuanto al desconocimiento acerca de los cuidados necesarios del cuerpo para el desarrollo de la práctica deportiva, más específicamente, de la práctica del fútbol. Sin embargo, decir que hacen esta actividad para hacer deporte,... "el deporte es salud"...y...."hay que moverse"..."esto me hace bien"; despierta el interrogante acerca de la concepción de salud, entrenamiento y actividad física que tienen estos sujetos en relación a esta práctica.

En el capítulo III, profundizaré el análisis del concepto de salud con una visión más amplia que el del estado de bienestar físico o corporal, entendiéndolo en un sentido más holístico e integral de las personas, involucrando más áreas y aspectos que hacen al mejoramiento de su calidad de vida y a la percepción de los factores benéficos de la práctica deportiva estudiada.

\section{Los vínculos.}

Acerca de los vínculos, las entrevistas y encuestas procuraron establecer el reconocimiento por parte de los participantes acerca de recibir o no el apoyo familiar a su participación en los Torneos de Fútbol para padres; y si logra reconocer algún cambio o modificación en su trato o comportamiento en otros ámbitos de relación social (trabajo, estudio, familia, amigos, deporte...) a partir de la práctica sistemática del fútbol del domingo.

Es notable el apoyo familiar a los participantes. Muchos se ven motivados a participar por sus propios hijos, encuentran un momento más para compartir en familia y con otras familias. En varias ocasiones he observado el acompañamiento familiar de hijos y mujer, sobre todo de los matrimonios más jóvenes. Es oportunidad en que las mujeres 
de las diferentes familias aprovechan para tomar mates, conversar, y los hijos e hijas jugar libremente por los espacios libres lindantes a las canchas. No necesariamente están pendientes del desarrollo del juego ni de la producción deportiva de sus hombres, los protagonistas de los partidos.

Otros lo valoran como un espacio personal importante, del cual no se quieren perder un solo día; pero si bien sus familias no los acompañan en persona, también entienden que es beneficioso para él, (el padre), tener un momento y lugar de esparcimiento propio.

No son tantos los que pueden percibir modificaciones en su comportamiento social; pero los que lo perciben, registran más de un ámbito (familia, trabajo) y más de un aspecto (más solidarios, más tranquilos, más amables y sociables).

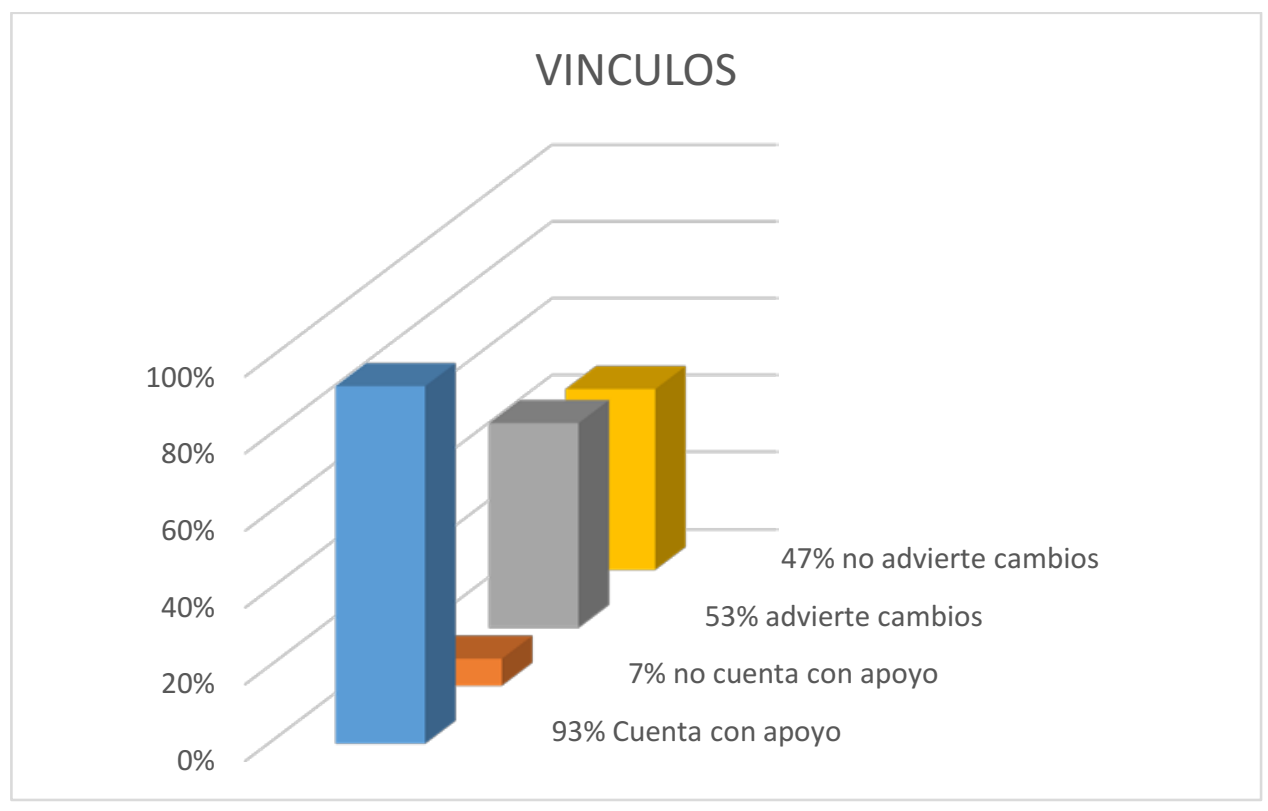

A pesar de la prisa por retornar al hogar para continuar con los compromisos sociales del domingo (el ritual del asado en la propia casa, la recepción de visitas o la vista a la casa de algún amigo) no impide la continuidad del tercer tiempo, aunque sea breve, casi siempre reservada al propio equipo, muy rara vez en compañía de rivales. Aquí se comparten bebidas de todo tipo, conversaciones sobre el partido, casi siempre anécdotas graciosas y simpáticas, bromas, chistes siempre en un clima relajado y cordial. 
Si está acordado de antemano, y sobre todo en el último horario del mediodía donde el domingo queda "cortado" como suelen expresarlo, los que pueden comparten el almuerzo en las canchas, aquí sí, casi siempre acompañados por todo el grupo familiar.

El siguiente gráfico permite un análisis más pormenorizado respecto de la importancia y el valor de recibir el apoyo y el reconocimiento familiar de la práctica deportiva como un bien preciado para el padre participante y su relación con advertir un cambio actitudinal y de comportamiento en otros campos de interacción social.

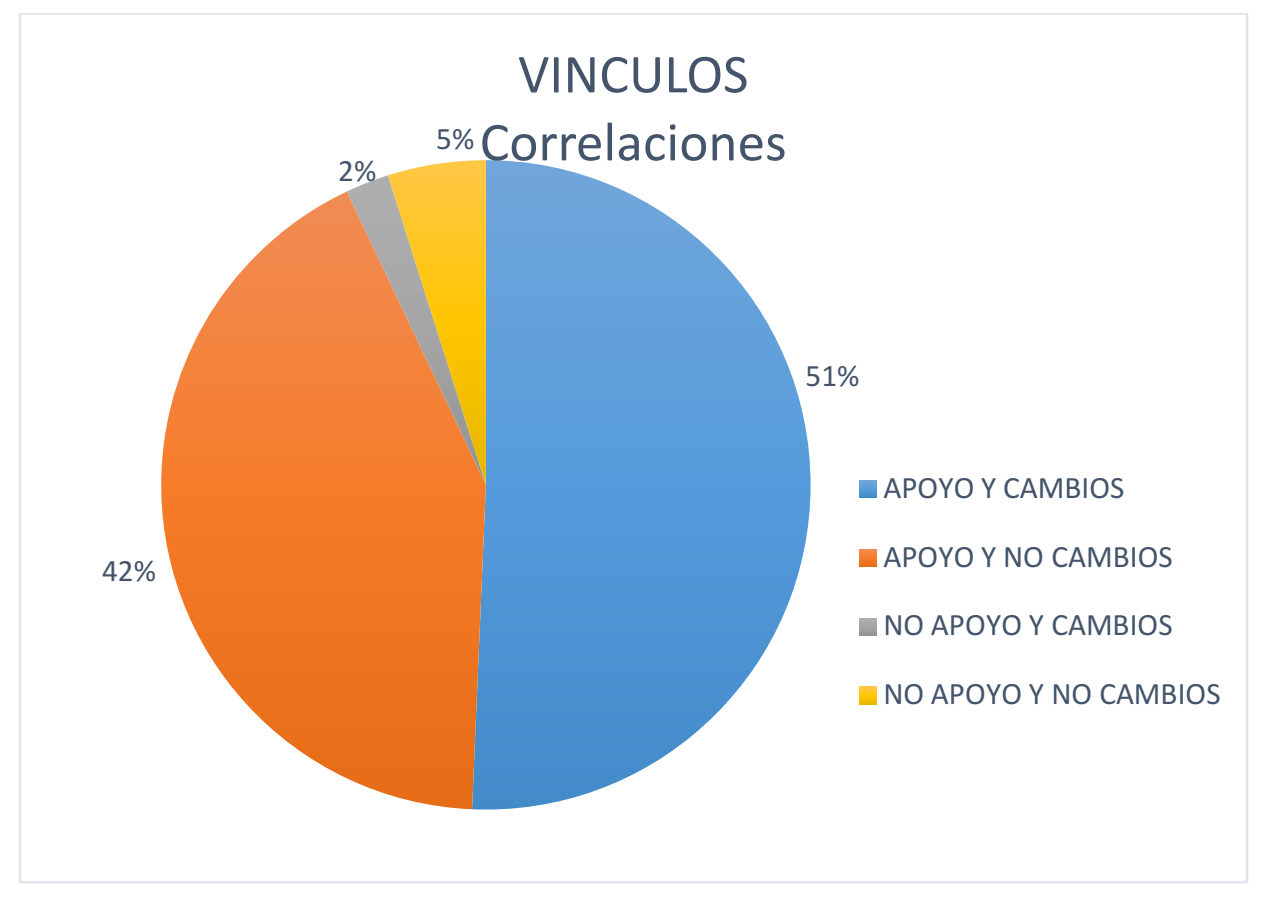

La mitad de los encuestados afirma que siente el respaldo familiar y que advierte cambios saludables de comportamiento a partir de la práctica deportiva:

-"esto es un cable a tierra"

-"Me distrae, acá descargo todas las tensiones de la semana"

-"Acá me siento libre,...con todos los muchachos hay buena onda”

-“En casa estoy mejor y en el trabajo también” 
-"El domingo que se suspende, iquedo toda la semana como loco!"

Son algunas de las expresiones recogidas de las entrevistas que dan cuenta de las atribuciones y contribuciones de la práctica del fútbol que los propios protagonistas perciben en sí mismos. También hay un número muy importante de sujetos que no relaciona la práctica deportiva con cambios manifiestos en su comportamiento y conducta en otros ámbitos de interacción social y valorizan la práctica por las acciones propias del deporte que se desarrollan en ellas.

Finalizado los partidos, sí se puede apreciar en su inmensa mayoría, a no ser que haya habido roces y dificultades durante la partida, un espíritu de cordialidad y caballerosidad, todos se saludan amistosamente, surgen disculpas, felicitaciones, abrazos fraternos entre rivales y jugadores del propio equipo. Se festeja sin agravios al rival y se respeta el triunfo y la derrota en ambos bandos. Prácticamente no he registrado rencillas, disputas o discusiones una vez finalizado los encuentros. Ni entre adversarios y muy pocas veces entre los propios del mismo equipo, algún reclamo por algún gol errado, algún error defensivo muy grosero, pero siempre es acallado o contenido por los líderes, capitanes o referentes de cada equipo.

Si bien no puede establecerse una correlación directa, indispensable o causal veremos en el próximo capítulo cómo se establecen estas interacciones entre los padres participantes, como se sostienen a lo largo del tiempo y como se interpretan a la luz de diversas teorías para convertirse en la opción deportiva elegida por este numeroso grupo de padres.

\section{Observaciones y Ampliaciones}

De los datos relevados del trabajo de campo en concreto, algunos que en principio no despertaban mayor curiosidad o importancia, resultaron interesantes de emparentar y discutir o poner de manifiesto.

Por ejemplo el caso del análisis en relación a la edad de los participantes, siendo mi intuición que la edad mayoritaria de los mismos era entre los 40 y 45 años y de los más jóvenes, más de 30 años; resultó ser que en realidad la mayor población de participantes se da en las franjas etarias de más de 35 y más de 45 años. Desde la observación participante pude apreciar como la aparición de grupos de jugadores cada vez más 
jóvenes comienzan a generar cierta grieta en la conformación de los grupos de hombres más grandes ya consolidados. Comienzan a aparecer conflictos de intereses en relación a la competitividad del equipo, la necesidad de ganar partidos, la pertinencia o no de que jueguen algunos de los jugadores más veteranos, renegando de su escasa aptitud o estado de condición física.

Otro dato interesante no pensado en su momento, es establecer cierto grado de igualdad en que la práctica del deporte posiciona a sus participantes en relación a los niveles socioculturales, económicos y de estándares de vida alcanzados por los niveles de instrucción, estudios y especializaciones laborales a los que ellos han accedido. Se advierte que prácticamente la mitad ha alcanzado estudios secundarios y la otra mitad terciarios y universitarios, siendo muy minoritaria la cantidad de participantes solo con instrucción primaria.

Es muy clara la tendencia y el comentario en el ámbito deportivo zonal y dentro de los padres de las mismas escuelas que no participan de este Torneo, la creencia de que es un espacio exclusivo y elitista. Comentarios del estilo

-"es un torneo para viejos chetos de Bella Vista"

-"ahí juega una manga de garcas"

-"nosotros ahí no cabemos"

son comunes de escuchar en reuniones y otros ámbitos casuales de encuentro, sobretodo de personas externas y que no participan del Torneo.

En realidad, desde los instrumentos del trabajo de campo se demuestra que no es tan así como puede interpretarse desde las miradas externas; si bien el universo estudiado está sesgado a determinada clase social, dentro del Torneo conviven distintos extremos de ese mismo sector acotada donde me resultan más cercanos los conceptos de aceptación e inclusión, que los de elitismo o exclusión.

Finalmente, ante la pregunta de algún comentario constructivo hacia la organización del Torneo, me resultaron muy llamativas las expresiones vinculadas a la sanción, el castigo y la rigurosidad por sobre otras posibilidades. Se evidencia una necesidad de control, corrección dominación y sanción a los equipos que no cumplen con cuestiones administrativas, llegan tarde y perjudican el inicio de los partidos, los errores de los 
árbitros y jueces de línea, la severidad en el castigo por las infracciones de juego, en fin , una suerte de reclamo en la firmeza del uso de la regla y la sanción a la transgresión, más que el aporte de nuevas ideas que aporten soluciones o propuestas que puedan mejorar la propuesta en términos organizativos.

Estos aspectos mencionados también han despertados mi interés y al encontrarse íntimamente relacionados con el tema central de los vínculos, relaciones y representaciones desarrolladas por los padres participantes de este Torneo de fútbol, decidí darles espacio y análisis en el capítulo III.

Por otro lado, otro aspecto relevado en esta muestra de datos tuvo que ver con la percepción de aprendizajes realizados por los participantes en cuanto a los contenidos técnicos, tácticos y reglamentarios del deporte que practican. Considerando este tema interesante, no resultó relevante a los efectos de encontrar enlaces prioritarios con el tema principal de investigación, sugiero postergar su análisis para un futuro estudio que habilite indagaciones acerca las posibilidades de aprendizajes efectivos a través del deporte. 


\section{CAPITULO III}

\section{Capítulo III - El análisis de los textos y los hechos}

\subsection{Los padres y el Torneo de Fútbol. Razones para juntarnos.}

Tomando en cuenta el concepto de habitus de Bourdieu (1993) quien considera que los modos de relacionarnos con nuestro cuerpo no son meras costumbres sino prácticas socialmente determinadas en las que se reproducen y plasman relaciones de poder de clase y género; es decir, designa esos atributos que hacen reconocibles a los grupos y sus prácticas: sus formas de hablar y pensar, y sentir, su forma de vestirse, sus gustos e inclinaciones, su aspecto físico, los lugares a los que concurren y las actividades que comparten. Para el autor la pirámide de clases sociales ofrece un perfil de contrastes que también se ilustran en las acciones de sus miembros; podría hablarse de un habitus deportivo que interviene en los modos de participación social de las personas, una serie de disponibilidades donde se transfiere lo deportivo a las relaciones sociales y viceversa, conformando un capital deportivo que se materializa en las interacciones sociales basadas en la práctica deportiva (Rodríguez Díaz, 2008).

Si bien desde este enfoque los individuos son pensados como personas capaces de elegir que estilo de vida llevar, se interpreta que esas operaciones no son infinitas ni idénticas para todos: uno piensa y cree lo que quiere pero en realidad es lo que puede, dadas sus condiciones materiales de vida y su conocimiento del mundo. Y si esto es así, esas vidas están inscriptas, arraigadas en las representaciones de poder que rigen nuestra sociedad. Si la ambición del logro, el deseo de triunfo, el individualismo se contraponen a la participación lúdica, al espíritu de humildad y a la cooperación y de reconocimiento social en las etapas infantiles y juveniles (Gutiérrez, 1994); cabe preguntarse qué buscan los adultos mayores de 30 años en su categoría de padres, en la participación de este torneo.

Ser partícipe de la práctica social implica el establecimiento de una relación especial con la misma y con el resto de la comunidad de practicantes. Según Mac Intyre (1987)

Toda práctica conlleva además de bienes, modelos de excelencia y obediencia a las reglas. Entrar en una práctica es aceptar la autoridad de esos modelos y la 
cortedad de mi propia actuación juzgada bajo esos criterios. La sujeción de mis propias actitudes, elecciones y preferencias y gustos a los modelos, es lo que define a la práctica parcial y ordinariamente.

Además de las reglas los deportes se caracterizan por convenciones sociales que determinan la forma en que cada uno de ellos se practica en diferentes contextos sociales y culturales (D’agostino, 1981). Los deportes están concebidos para evaluar la destreza en el ejercicio de habilidades constitutivas propias que llevan al éxito de la disputa. Hacer uso de faltas, juego brusco, o penalizaciones socaban el reto principal de la actividad propuesta; derechos y obligaciones de los participantes, virtudes que deben manifestar, compromiso y dedicación de actuar sensatamente ante las presiones y secuencias del juego, son expresiones propias de quienes se piensan como deportistas (Simon, 2006).

Cuando un grupo de padres desea participar de este Torneo, sabe a qué realidad está sometiéndose porque es la que él mismo busca y recrea. El encuentro con un par (padre) sugiere una interpelación hacia el deporte en el que quiere participar. Aquél en el que encuentre ese equilibrio, que ya está en buena medida generado por la categoría de padre de escuelas privadas de determinado contexto social, económico y cultural. Sabe con lo que se va a encontrar, encuentra una población con características semejantes, intereses parecidos, códigos y decodificaciones de un lenguaje de gestos, acciones y actitudes que los emparentan y en algún modo igualan en el desarrollo de ésta práctica. En este sentido, es que este grupo de padres responde al cuestionamiento de con quién hago deporte, con qué sujetos deseo compartir esta experiencia, con quienes y de qué manera quieren relacionarse.

Trascender, ir más allá de lo ordinario en el sentido de la superación y la excelencia que se concreta en una práctica cultural y social, la sublimación de comportamientos primarios, individuales y egocéntricos en bienes culturales superiores, en beneficio del bien común del equipo, de lo grupal. La experiencia en el campo de juego también surge de esta manera: el sentimiento de unidad de formar parte de algo más grande que se siente de una manera intuitiva, como formar parte de un equipo (Irundáin, 2006).

Esta misma identificación, este grado de representatividad elegida tampoco le permite escapar de lo que Elías (1987: 56) da a conocer como la versión del proceso civilizatorio donde el deporte se convierte en una nueva figuración del control de la violencia y las emociones. Según él, la mayoría de las civilizaciones modernas generan 
alguna actividad como remedio para las tensiones por el sobreesfuerzo que ellas mismas ocasionan. En este caso, ligadas al tradicional mandato de la masculinidad dominante sobre la figura del padre, en tanto del proveedor principal del sustento del hogar. Estas actividades deberían además proveer una relativa descarga de agresividad y violencia controlada, que permita la liberación de la excitación y la emoción, también de manera controlada. Las sociedades urbanas industrializadas poseen una alta dosis de rutina, monotonía y civilización, por tanto, la necesidad de crear actividades recreativas y de esparcimiento que puedan generar distintos grados y manifestaciones de emoción agradable en forma limitada y controlada como los deportes, es particularmente intensa en la actualidad.

De alguna manera, estas propuestas recreativas provocan sensaciones de placer, miedo y riesgo sin el peligro y la severidad que conlleva la vida laboral y productiva. Las alternativas del ocio permiten que estas pulsiones y emociones fluyan con más naturalidad y espontaneidad pero a su vez, nunca pueden ni deben desbordarse. Al parecer las personas que viven en comunidades deben auto controlarse, imponerse restricciones a la expresión de sus impulsos, afectos y emociones por su propio bien y supervivencia de forma individual y como grupo. Este proceso de adaptación debe ser aprendido y es muy costoso para aquél sujeto que nos sepa aprehenderlo e internalizarlo; entiendo este espacio de encuentro deportivo como una instancia superadora ya que propicia la oportunidad a los sujetos de hallar una forma de práctica ajustada a sus posibilidades e intereses, a los códigos y formas de comportamiento que aceptan y acuerdan.

El uso del tiempo libre destinado al deporte se encuentra en esta contradicción: hay menos tiempo para hacerlo pero más medios. Se necesitan sesiones deportivas que duren poco y de mucha intensidad. A la escasez del tiempo se suma la escasez de espacio, por ende a la proliferación de nuevos estilos deportivos y adaptaciones de deportes convencionales destinados a algunos sectores sociales diferenciados. Esta fugacidad solo es recurrida por aquellos que disponen de menos tiempo libre, como las clases medias acomodadas con agendas apretadas. Disminuir los espacios es también reducir el número de jugadores que puedan participar de esta nueva modalidad y esto hace que aparezcan razones elitistas para practicarlo. Cuanto mayor es el número de practicantes de una modalidad, mayor será su popularidad, la accesibilidad social que habilite la convocatoria (Rodríguez Díaz, 2008: 41). 
Pese a pertenecer en buena parte a esos sectores sociales, los sujetos participantes han podido establecer en el Torneo de Fútbol para padres un espacio reservado al tipo de práctica que quisieron desarrollar. En nuestro caso particular, la reducción al número de jugadores que planteó la organización original, pudo verse influenciada por esta mirada, o bien por un pensamiento mercantilista. Los participantes vieron alterada la condición de grupo y eso fue lo que los motivó a desligarse de esa organización y generar otra, donde las reglas, la esencia y los desafíos sean los genuinos. A la pregunta de dónde se hacen las prácticas sociales, este grupo de padres encuentra la manera de conservar un espacio ya apropiado, ya ganado, a no perder la posibilidad de continuar una práctica social que en todo es satisfactoria y atractiva. Este espacio apropiado se da entonces por un proceso más social que económico, más simbólico que material ${ }^{12}$ primando la necesidad de sostener los equipos, los grupos, los vínculos y relaciones tramadas a lo largo de los años en que se fue construyendo el Torneo.

Al momento de cambiar de organización, cuando el torneo dejó de realizarse en el Colegio de la Providencia y pasó al predio de Virgen Niña, la escisión de los equipos se produjo como producto del tipo de juego que querían hacer, que querían desarrollar los protagonistas. Todos estaban muy conformes con el Torneo de fútbol de la Providencia, prácticamente no había quejas sobre la organización. Sin embargo, casi sorpresivamente, la organización pasó a querer implantar un torneo de futbol de 8 participantes por equipo en cancha. Creo que lo que llamó más la atención es que no hubo consulta a los participantes sobre esto. Fue una decisión de los organizadores, padres del Colegio de la Providencia, de modo unilateral, como suponiendo que todos iban a seguir prendidos del torneo.

Pues bien esto no fue así. Al reducirse el número de jugadores cambiaban muchas cosas más. Las plantillas de buena fe, las listas con los integrantes de cada equipo se reducían; lo principal, los equipos, los grupos tendrían que desmembrarse en por lo menos dos o más. Algunos equipos contaban con más de 20 jugadores en el plantel, ya les costaba hacer participar a todos por algunos minutos todos los domingos, pero la constitución del grupo lo sostenía y el reglamento del torneo también, ya que propiciaba hasta 6 cambios en el juego y una cantidad libre en el entretiempo ${ }^{13}$.

\footnotetext{
${ }^{12}$ Análisis de las dialécticas espaciales: Las prácticas espaciales, las representaciones del espacio y los espacios de representación, (Lefebvre, 1991) en Rodríguez Díaz (2008: 24).

${ }^{13}$ Ver anexo Reglamento del Torneo de fútbol para padres Virgen Niña.
} 
El otro problema importante es que para mucho de los participantes, entre los cuáles me incluyo, la práctica deportiva del fútbol es de 11 jugadores por equipo, en "cancha de once" como se suele decir. El fútbol reducido en todas sus variantes conocidas 5,7 y 9 integrantes por equipo en cancha, son acercamientos a un modo de jugar a la pelota donde pueden privilegiarse otras habilidades, técnicas, tácticas y lógicas que justamente tienen que ver con la dimensión de las canchas y la cantidad de participantes.

Pero los que queremos jugar al fútbol, queremos hacerlo en el campo con las dimensiones reales, árbitros y jueces de línea, la aplicación de las reglas oficiales y el reconocimiento de propios y adversarios de la lógica del juego que nos convoca. Así fue como comenzamos a consultarnos sobre cuantos querían sostener el Torneo de fútbol del Colegio de la Providencia, resignando el número de jugadores y las dimensiones del campo, pero manteniendo un lugar conocido, ameno, ya familiar para muchos; y quienes se animaban a reorganizarse y formar un nuevo torneo de fútbol 11 manteniendo la idea original de aquél, el espíritu de convivencia y de competencia que a todos nos gustaba.

Rápidamente encontramos 6 o siete grupos muy fuertes y tradicionales del aquél torneo que querían mantenerse en este orden pero costó un poco más poseer figuras referentes para respaldar la organización. La idea de hacerse cargo de la organización del Torneo, significaba disponer de tiempos en la semana para resolver las cuestiones administrativas, y en toda la jornada del domingo para estar en los detalles y necesidades de cada fecha del torneo y con movilidad para asistir a más de una sede. La situación decantó en dos padres de uno de los Colegios, pero en respaldados una comisión abierta conformada por delegados de todos los equipos e instituciones representadas que regularmente se reunieron y se siguen reuniendo para dar forma y ajustes al torneo vigente.

Al año siguiente, varios de los equipos que permanecieron una temporada en el Torneo de la Providencia, se pasaron al Torneo de Virgen Niña, comentándonos que estaba todo bien, pero que preferían jugar de 11, que querían volver a reunir el equipo que tuvo que separarse para la constitución de plantillas más pequeñas y que extrañaban enfrentarse con algunos equipos con los que ya habían desarrollado una sana rivalidad, y una cordial y respetuosa competencia. Por supuesto la bienvenida a los conocidos equipos de temporadas atrás fue mucho más natural y rápida de lo que ellos mismos imaginaban. A todos nos dio gusto reencontrarnos con aquellos que habían preferido por 
una o dos temporadas otra experiencia deportiva, pero además afianzó la idea de los organizadores en que estaban haciendo las cosas muy bien y ratificó la confianza empeñada por todos los participantes en ellos. Esta apertura posibilitó abrir más cupos para nuevos equipos e Instituciones que actualmente participan del Torneo, (24 a la fecha del desarrollo de la investigación, 32 a la fecha de la entrega de esta tesis, en 2015).

Desde el punto de vista organizativo, y a pesar de haber cambiado dos veces de sede y de referentes asociativos, el torneo conserva aspectos que lo definen en los intereses de sus participantes. Por ejemplo, la elección del día domingo por la mañana para el desarrollo de sus prácticas es sumamente bienvenido dado que aparentemente no influiría tan negativamente en el desarrollo del fin de semana de planificación familiar.

Por lo general, hombre, el padre en este caso, ya ha destinado el día sábado al grupo familiar, al acompañamiento en las actividades deportivas de los hijos; el viernes o el sábado a la noche, en la salida al cine, teatro, cena con amigos u otros adultos. El domingo por la mañana parece ser un horario donde los sujetos participantes destinan con buen agrado, a pesar del frío en la temporada de invierno y de renegar si toca el horario del mediodía porque cancela o anula la posibilidad de otras grandes tradiciones argentinas y del contexto estudiado (tradicionales localidades del conurbano bonaerense San Miguel, Bella Vista): la misa católica dominical y el asado familiar. Todo puede postergarse o reacomodarse para no perder la instancia deportiva del torneo de futbol para padres.

Esta condición de día y horario es ideal para el hombre porque resguarda su condición de padre de familia, ya que ocupa el espacio familiar menos comprometido en el uso de su tiempo libre, de su propio espacio destinado a satisfacer su necesidad íntima de la práctica deportiva, sin desatender sus funciones de padre y esposo. De aquí también que sea ampliamente apoyado por su entorno familiar, ya que no perjudica, al menos no en demasía, el funcionamiento del fin de semana familiar. Ya ampliamos el concepto del acompañamiento de los niños, y en menor medida de los jóvenes y de las mujeres, al campo de juego, pero aún las familias que no lo hacen, y donde el padre concurre en solitario al partido, estas apoyan y comparten la idea su participación.

Si bien casi nadie quiere perderse la oportunidad de jugar el domingo, la condición de participante no prescribe obligaciones más que el compromiso que se asume con el grupo. Es decir, que cualquiera que tenga un compromiso familiar (cumpleaños, 
casamientos, etc.) o laboral (viajes y traslados) de carácter impostergable, adquiere dificultades de inclusión o participación en los equipos.

La organización contempla fechas de conmemoración social como día del padre, de la madre y del niño para no jugar partidos de fecha completa; al igual que los fines de semana extendidos por feriados, considerando que son espacios y momentos que pueden y deben ser compartidos por toda la familia.

El creciente interés por participar en el torneo en los últimos años ha generado que se gestionaran nuevos predios para la habilitación de más sedes y canchas disponibles para albergar más partidos. Se habilitaron listas de espera para propiciar la inclusión de nuevos equipos representativos de nuevas instituciones escolares. $Y$ aquellos que lo hacen por primera vez se los compromete a participar bajo las reglas y el espíritu de confraternidad que tiene el torneo. Se espera que los que se integran a ésta práctica, se sientan identificados con los ideales e intereses de la misma, no solo para poder entrar, sino en la consolidación de su comportamiento a lo largo de todos los partidos de toda la temporada.

Ésta condición de control no es ejercida por un comité en particular ni por una comisión ad hoc, sino que en reunión plenaria donde todos los equipos tienen representantes con voz y voto se plantean éstas situaciones y condiciones que pueden redundar en la aceptación y continuidad de un equipo, como en la desafiliación del torneo.

Evidentemente, el monitoreo, la supervisión y el control de todos los detalles organizativos es necesario para la supervivencia de esta práctica. Siempre hay reclamos de todo tipo y me llamó mucho la atención como los propios participantes opinan en este aspecto. En este punto parecería que la rigurosidad, la seriedad, y tomaran paso y espacio sobre el atractivo lúdico, recreativo y de esparcimiento que invita esta práctica.

La manifestación pidiendo la sanción a quienes llegan tarde y atrasan la realización de toda la jornada, la penalización severa para quien transgrede las normas, la exigencia de conseguir árbitros y jueces más estrictos y de mejor formación académica y reglamentaria, la fiscalización de los juegos con veedores, planillas de buena fe y control estricto de jugadores e inclusiones que verdaderamente sean padres de alumnos de las escuelas a las que dicen representar, son algunos de los reclamos y opiniones relevados oportunamente, y fueron ajustes que la misma organización requirió afrontar para satisfacer a los participantes que así se pronunciaban. 
Quiero decir con esto que aún en instancias recreativas, lúdicas y de esparcimiento, el control social aparece como necesario y los mismos participantes se encargan de solicitarlo, implementarlo y resolver las situaciones que pudieran poner en peligro el espacio de juego. Elías (1996: 91) alerta de como la interdependencia de todas las actividades tanto públicas como privadas, del orden del trabajo como del ocio, exigen un manto de control y de restricciones que las regulen. Así en tanto, la concepción antagónica entre "trabajo" y "ocio", entendiendo la primera como la manera de ganarse la vida, el tiempo dedicado a una práctica profesional especializada por la cual se recibe una remuneración y está cargada de tareas, deberes morales, responsabilidades y obligaciones y a la otra, caracterizada por el disfrute, la complacencia y la relajación; el placer de hacer lo que al sujeto le plazca o simplemente no hacer nada, es al menos insuficiente para explicar el uso y distribución del tiempo en la sociedad de hoy.

Otro aspecto a destacar en relación al concepto de padre, es la nueva figuración que alcanza esta condición en cada Colegio, a partir de la participación de los padres en el Torneo de Fútbol. De manera dispar en cada Institución pero nunca pasando desapercibida, la participación de los padres en el Torneo de Fútbol habilitó una nueva presencia rol y valor de los mismos en la Institución educativa. Desde la aparición en los actos escolares de fin de año para mostrar los trofeos y menciones alcanzadas durante el Torneo y compartirlos con la comunidad; y los de comienzo del ciclo lectivo con el objetivo de reclutar nuevos participantes y comentar y difundir entre los nuevos padres que se inician en la escolaridad de sus hijos, pasando por las editoriales y notas en los periódicos y revistas internas de cada institución. En varias escuelas participantes, el desempeño de la actividad de los padres en el Torneo de Fútbol es seguido por los alumnos y publicado en las revistas de circulación interna de las escuelas, con publicaciones anuales, semestrales o trimestrales. Es común ver cada tanto a jóvenes que vienen a tomar notas para redacciones, fotos y videos para subir y publicar en los diferentes formatos habilitados en las Instituciones.

De las entrevistas y observaciones se desprenden algunas consideraciones importantes en relación a esto, vinculadas los espacios que las escuelas y colegios habilitan para los encuentros, reuniones, entrenos y organización de los equipos. Hay instituciones que abren sus patios, gimnasios y campos de deportes para que los padres realicen sus encuentros y entrenamientos semanales. Otras, asociadas generalmente al éxito deportivo, habilitan sus espacios para almuerzos, reuniones y celebraciones. 
Los niños, sobre todo los más pequeños en escolaridad primaria, acompañan frecuentemente a los padres a los encuentros deportivos de los domingos y entablan nuevas relaciones con sus compañeros de escuela y con otros niños de otras escuelas, generando nuevas relaciones y amistades, aunque sean espontáneas y breves; a los niños les resulta sumamente más sencillo efectuarlas. Puedo interpretar que los hijos de los padres participantes ven con muy buenos ojos su participación activa en el Torneo. Vivan sus nombres, alientan a los padres compañeros del suyo, hinchan por su escuela, pero fundamentalmente, asisten con verdadera alegría a acompañar a sus padres al encuentro deportivo, son críticos con el juego, con los árbitros, viven la experiencia deportiva del espectador con el plus de respaldar el protagonismo de su padre como jugador.

Aquí también deseo detenerme para plantear cierto grado de responsabilidad que conlleva para los sujetos la representatividad institucional y la presencia de niños en el campo de juego. Existen ciertas conductas con notas ciertamente moralizantes que contribuyen al control de emociones y situaciones violentas que podrían ocasionarse en la disputa del partido y ante la presencia de sus hijos y de hijos de otros compañeros y adversarios, se ven seguramente mitigadas y moderadas.

Por lo pronto, sí se presenta como una situación de alta responsabilidad en tanto el grupo de padres y cada uno de los jugadores del equipo adquiere el grado de representatividad institucional del colegio al cual representa y al cual concurre su hijo. Obviamente la exposición a la que se ve reflejado el padre deportista es muy grande en tanto demuestre buenos hábitos de comportamiento, como los más deleznables e impropios.

En este sentido, el torneo fomenta manifestaciones de la virtud al entregar premios "fairplay" anualmente y al mejor jugador de cada partido, reconociendo el juego limpio y la búsqueda del triunfo por los medios justos, honestos y permitidos y en el desafío de la búsqueda del buen juego y la excelencia deportiva. Estas restricciones en las manifestaciones observadas podrían problematizarse en tanto cuestiones reprimidas por la presencia de los niños o bien circunstancias aleccionadoras y aprendidas como correctos hábitos de comportamiento deportivo a partir de la participación en el Torneo de Fútbol.

Existen algunas diferencias entre los que piensan que el deporte participa en la configuración del carácter y quienes están a favor de creer que su logro es manifestar el 
sistema de valores que cada persona o grupo ya tiene incorporado. La adquisición de valores se obtiene a partir de la interacción con los otros, con otras personas, ya que no tienen una entidad real, palpable y objetiva, no pertenecen a los objetos y cosas sino que dependen de la relación con un alguien que los ponga en valor y legitime. Los valores en abstracto no significan mucho más que ideales a alcanzar que deben guiar nuestros actos, nos hablan por lo general de nuestros defectos y carencias y de superar las mismas. Ésta búsqueda mueve a la voluntad y provoca el deseo que esta realidad se modifique, hacia bienes y virtudes compartidos socialmente (Gutiérrez San Martín; 1995).

Milton Rokeach (1973: 5) entiende que los valores son adquiridos a través de los procesos de socialización y transmisión entre los seres humanos "es una creencia duradera donde un modo de conducta o un estado último de existencia es personal y socialmente preferible a un modo opuesto". Los autores Robert Butcher y Ángela Schneider señalan que los participantes que toman seriamente un deporte, se convierten en parte de esa práctica, ya que a través del tiempo comprenden sus valores, y cada uno en diferente medida los adoptan como propios ("Respect for the game"). Por esta razón es importante que el deporte se practique de forma moralmente deseable para permitir el desarrollo moral de los jugadores y expresar un conjunto de valores de la sociedad.

De acuerdo con Escamez (1986) la persona está en

un constante hacerse a partir de sus propios actos, es decir, su propia indeterminación psicobiológica originaria va concretándose en una forma de ser y de actuar cada vez más definitiva, en la interacción dinámica con la realidad física y sociocultural en la que vive, con el contexto en que se desarrolla.

Este contexto juega un papel activo sobre el sujeto provocando en él determinadas conductas y modificaciones de valores personales, que, a su vez, a través de los cambios producidos en la conducta y manifestados en el comportamiento, puede producir nuevos cambios en su entorno. En todo caso, las prácticas deportivas se constituyen en construcciones reales que recogen el crédito de una sociedad dada, una representación unánime o diferencialmente compartida por distintos sectores sociales y se vuelven definiciones y acciones que obedecen a modelos de esa área social y cultural. $Y$ estas representaciones, estas creencias no son solo fantasías, suplementos sin incidencias en la naturaleza de las cosas, sino que a partir de ellas los hombres actúan sobre la realidad 
y esta sobre ellos (Le Breton, 2008: 180-182). En este sentido, el contexto no es solo motivador de la conducta, sino el sustrato desde el que la persona está configurándose permanentemente en sus características fundamentales, y en el caso de estudio se expresan a través del fútbol, la práctica elegida por estos padres.

Ahora bien, podría ser que esos valores no representen más que un consenso social de una comunidad deportiva determinada. O podrían promoverse valores partidistas o sectarios a través de él; o elevar las normas morales de algunos grupos sobre otros. Valores generales como la búsqueda de desafíos de la excelencia y de la superación de obstáculos se encuentran en muchas actividades. Sin embargo estos valores ocupan un papel central en la teoría o interpretación del deporte ya que obedecen a otros valores básicos como el respeto, el juego limpio.

Solo algunos participantes, reconocieron en las encuestas, encontrarse más tolerantes con las limitaciones propias y ajenas en cuanto a las habilidades y destrezas deportivas, más prudentes en tanto reclamos y protestas dentro y fuera del ámbito del torneo, y con mejores tratos con sus compañeros, amigos y familiares. No podríamos establecer una relación causal entre la práctica deportiva y la modificación de conductas y comportamientos deseables de estos deportistas, pero si podemos decir que es un escenario propicio para que se manifiesten.

El que una práctica pueda mantenerse en su integridad dependerá (también) de la manera en que las virtudes (justicia, honestidad, valor y veracidad por sobre todas) puedan ejercitarse y que sirvan de apoyo a las formas institucionales que son soportes sociales de la práctica (Mac Intyre, 1987: 258); de tal manera que estas virtudes la justicia, la honestidad, el valor y la veracidad se constituyen soportes virtuosos de la práctica. Siendo una virtud una cualidad humana adquirida, cuya posesión y ejercicio tiende a hacernos capaces de lograr aquellos bienes que son internos a las prácticas, y cuyas carencias nos impide efectivamente el lograr cualquiera de tales bienes. El que alcanza la excelencia en una práctica, el que juega bien a algo (al fútbol, en nuestro caso) disfruta lo mismo su éxito, como de la actividad necesaria para alcanzarlo, aunque no supere los límites o no logre los objetivos, actúa y se esmera para lograrlo (Mac Intyre, 1987: 260). El desarrollo del Torneo de fútbol para Padres es vivido por sus participantes de esta manera, la búsqueda del gozo es en gran parte participar del Torneo aunque todos saben que pocos ganan, pocos salen campeones. La búsqueda de la excelencia y de los bienes internos del deporte está atravesada por la búsqueda de la emoción, por el 
ansia de revivir cada domingo la experiencia de compartir el disfrute de la competitividad entendida en los términos en que se juega este torneo.

\subsection{El fútbol en el Torneo de Padres. La elección de la práctica deportiva.}

En la continuidad de este análisis quiero destacar como se siente, como se vive el deporte y el fútbol en este contexto. Elías y Dunning (1996: 268) explican que probablemente sea el carácter oposicional del deporte lo que explique la identificación colectiva como grupo, a la propia, del propio equipo y a la del otro, el adversario de turno. El enfrentamiento sirve para reforzar la pertenencia e identificación, en este caso con el Colegio al que representan, sumada a la valoración de la condición filial de padres de familia. Sin embargo, las figuraciones sociales que se representan en las prácticas deportivas no están desligadas de las interdependencias y polarizaciones que en él se manifiestan. Las hay de diferente orden, pero en general, y en particular del caso estudiado, el éxito de la propuesta radica en la búsqueda del equilibrio de tensiones entre estas polaridades, siendo las más explícitas la polaridad global entre los dos equipos, la polaridad entre tensión y cooperación entre los dos equipos y sobre todo la polaridad entre la identificación afectiva con el contrario y la rivalidad hostil hacia él. Este delicado equilibrio de tensiones que se suceden en la dinámica de grupos deportivos que practican fútbol en particular, las que se dispensan entre la cooperación y la tensión y viceversa; como la de la equiparación de fuerzas en tanto habilidades y capacidades técnicas y tácticas referidas al juego y en cuanto a la configuración de las polaridades entre los equipos contendientes son claves para comprender las prácticas y las interacciones que suceden en ellas. (Elías, 1996: 239 - 242).

Ahora, ¿cómo es percibida esa rivalidad en el contexto investigado? Simon (2006) plantea que el deporte competitivo puede entenderse como una actividad que tiene un elemento cooperativo muy significativo. Los competidores consienten en tomar parte por la competición con el propósito de evaluarse y medirse mutuamente, contrastar aptitudes y limitaciones y buscar la excelencia deportiva. Esto solo es posible si los adversarios participan de una manera justa e intensa para que dicha evaluación conformada por las reglas e informada por los principios del deporte en cuestión pueda ser aceptada y llevada a cabo. Es un contrato social subyacente e hipotético en el cual los competidores voluntariamente aceptan la responsabilidad de jugar de determinada manera. Así vista, la 
contienda deportiva es cooperativa en un sentido muy significativo, ya que la cooperación es del adversario. Necesito del otro y el otro necesita de mí para poder realizarse.

El modelo de la búsqueda de la excelencia a través del reto, del desafío, implica que el proceso competitivo y no solo el resultado es lo importante. Un buen competidor disfruta por la presión de la prueba y quiere ser exigido en nuevos y justos desafíos. Concebido como búsqueda mutua de la excelencia, ambos equipos pueden sentirse meritorios y orgullosos de sus logros, por encima del resultado, de vencedores y vencidos. Esta particular manera de ver la contienda deportiva se ajusta a las experiencias vividas durante estos años en el Torneo de Fútbol para padres. Lógicamente el interés por ganar los partidos en disputa existe, sin embargo, en diferentes tonos y matices, los participantes manifestaron en las entrevistas y en las encuestas el interés y el valor de jugar más que el de ganar.

Del análisis de los datos relevados en el capítulo II, la recuperación del espacio de juego para el adulto masculino parece ser una alta motivación en la búsqueda de nuevas prácticas sociales. Siendo ésta la categoría manifestada como preferente por los participantes, a la hora de adjudicar valor a los partidos (ganar o jugar) podríamos referenciar a Suits (1979: 123-126), quien esgrime que "La actividad lúdica interrumpe la experiencia cotidiana normal de las conductas guiadas por la urgencia de la necesidad. El Jugar es relacional". Para el autor, el Juego y el Jugar pertenecen a órdenes diferentes. Los juegos son cosas, objetos, actividades; el jugar es la actitud hacia la cuál va dirigida ${ }^{14}$.

Para sostener la integridad y fluidez del juego se elaboran los reglamentos que incluyen penalizaciones que deben compensar la falta y restaurar rápidamente las condiciones de juego. Lo que caracteriza a los deportes del resto de los juegos es que las reglas limitan los medios disponibles para lograr los objetivos respectivos, para poner a prueba ciertas habilidades físicas, saberes prácticos que se distinguen del saber teórico. Directamente relacionadas con estas habilidades, cada deporte adquiere su identidad y sus estándares de excelencia propios (Kretchmar, 2006: 106). El desafío de estos hombres está dado entre otros aspectos en demostrar la eficacia de esas habilidades y saberes prácticos a determinadas edades donde muchas veces aparecen limitaciones

\footnotetext{
${ }^{14}$ El juego es un problema artificial que requiere la identificación de un objetivo para alcanzar a resolver de al menos 3 maneras: Al azar o la suerte; La habilidad (holísticamente incluye: pensamiento, emoción y acción motora); La estrategia (selección de acciones y recursos). El fútbol, deporte en cuestión practicado por los sujetos referentes al estudio, posee de las tres.
} 
físicas propias del paso del tiempo. Surgen en entonces otros saberes, algunos relacionados con la teoría, con los saberes tácticos, analizar cómo conviene jugar ante determinados rivales, otros con la experiencia, el saber posicionarse en la cancha, como correr menos y más eficientemente, manejar los tiempos del partido, cuando acelerar y cuando bajar el ritmo y la intensidad del juego, jugar con más picardía y exponer el cuerpo lo menos posible, sobre todo ante el rigor y la plenitud de los más jóvenes. Entre otras cosas, jugar bien implica reaccionar de manera inteligente ante las estrategias escogidas por el contrincante y las jugadas elegidas para sortear esas estrategias y validar las propias. En muchos casos los fracasos o derrotas deportivas ofrecen a las personas y a los equipos la oportunidad de evaluar su temple y superar la adversidad. Si ganar no lo es todo, es un indicador significativo de que se hizo frente y se respondió adecuadamente al reto (Simon 2006: 172). El fútbol, la manera de jugar al fútbol en la Argentina como se explica en el Capítulo I, referencia justamente a aquellas habilidades físicas y saberes prácticos legitimados como propios e ideales para los protagonistas de este estudio. No se trata de jugar en cualquier torneo de fútbol, ya que de estos hay muchos casi a la mano de quien quisiera armar un equipo de fútbol barrial y jugar en cada cancha de cualquier potrero o complejo de futbol 5 que los organiza cada fin de semana. El interés está en jugar y competir con alguien que va por los mismos objetivos, con las habilidades similares y las limitaciones parecidas, con muchas más cosas en común que en disputa.

Si el fútbol es definido como una práctica social significante entre los argentinos y en particular constituye la práctica elegida por este grupo de padres, deberíamos prestar atención a las acciones, objetivos, reglas, roles y funciones, que lo distinguen, y a sus bienes internos y estándares de excelencia buscados a través de su práctica. Estos últimos proveen a las prácticas sociales de una identidad propia y única que enriquecen a las personas que lo practican y en casi todos los estilos de vida y sectores sociales de nuestro país, el fútbol es reconocido y valorado. Los estándares de excelencia están relacionados con el desarrollo y nivel de ejecución de los bienes internos logrados por la comunidad de participantes, que posibilita la creación de espacios y lugares para desarrollar el fútbol de acuerdo a sus intereses y posibilidades; permite su existencia, mantenimiento, evolución y avance progresivo. Así son valorados de diferente manera según dónde y con quienes se practique el fútbol, pero siempre requiere lealtad a estos estándares y a quienes lo hacen posible y lo viven como un estilo de vida, que se 
actualiza en su evolución con cambios que promueven la atracción, belleza y significado por esta práctica.

La competencia significa involucrarse con el contrincante en la misma actividad con la intención de demostrar la superioridad de sus habilidades físicas en efecto evaluativo y comparativo con el rival (Kretchmar, 1975: 39). Cuando el aspecto del resultado (comparativo) se privilegia, este se subordina a la prueba, las habilidades a la que ésta demanda y a lo que el rival posibilita. Las reglas constitutivas (lo permitido y lo no permitido) y las regulativas (restauradoras o compensadoras del juego) crean las condiciones para la aparición de varias y nuevas formas de ejecución de movimientos, lo que determina el nivel de importancia de estas habilidades es el grado en que ellas contribuyen a la definición del problema. Los juegos competitivos nos ponen de frente a situaciones seductoras en donde "el hacer" de estos proyectos constituye la única recompensa. Mientras los juegos son entidades significativas por derecho propio, encuentran su finalidad más elevada cuando atraen la experiencia lúdica. En este sentido, cabría diferenciar el juego (the game) como el tipo de actividad y el jugar (play) por la experiencia, dimensión o espíritu lúdico (Kretchmar, 1975: 36). A consideración de este autor, los juegos requieren de la lógica convencional. La capacidad de crear, vivir y entender de acuerdo a las relaciones estipuladas, las reglas a la cuales nos sometemos y observamos. También requieren de una lógica formal, de los medios autorizados que permitan alcanzar los objetivos que plantea el juego, estaríamos definiendo una posible ética del juego. Por último, demandan la capacidad de encontrar una lógica de hacerlo porque sí, como un fin en sí mismo, una la lógica de la gratuidad, de encontrar el grado de dificultad apropiado a vencer. La experiencia lúdica entonces, aparece como una distracción de la lógica de la utilidad y por otro lado, el juego es algo que puede activar o estimular esta distracción. Así, los juegos funcionan como imanes de la experiencia lúdica, buscamos el drama y la tensión, la incertidumbre del triunfo o del éxito, de hacer algo extraordinario, distinto y glorioso pero al hacerlo a través del juego o del deporte en nuestro caso, evitamos ciertos riesgos y peligros de la vida real. En realidad, nos enfrentamos a otros riesgos, propios del desafío de la práctica creada.

Entonces, los juegos resultan actividades privilegiadas sobre otros tipos de ocio presentando una opción más sólida o significante entre las personas. Las personas qué prefieren las prácticas deportivas por sobre otras posibilidades del uso del tiempo libre realizan una búsqueda de nuevas emociones que no encuentran o no aparecen en su 
vida cotidiana o las han tenido en algún momento de sus vidas, y esta aparece como la instancia de recuperarlas activamente y no solo rememorarlas como un recuerdo añorado. Lo cierto es que aquellos participantes de nuestro estudio que realizan una verdadera elección por el juego y el jugar, adhieren a esta propuesta del Torneo de Fútbol para Padres aceptando los desafíos que ella implica y construyendo nuevos objetivos a alcanzar por cada equipo y entre todos en común.

Cuando uno se involucra libremente en un proyecto interesado en el "hacer" de esa actividad, y ese "hacer" constituye una recompensa en sí mismo, entonces dicha actividad entra en el dominio de la experiencia lúdica, del jugar. Estas experiencias cobran valor cuando hay tensión, por la incertidumbre que el juego genera y por la intriga por el resultado. Puede perderse cuando la actividad y el objeto ya no son intrínsecamente satisfactorios y precisan de una retribución externa; o bien, por el desgaste de las cualidades internas de la actividad. Si el objetivo del juego puede alcanzarse fácilmente, la repetición extingue el deseo, la fatiga, agobia el espíritu (Schimtz, 1979: 68).

En el caso de estudio, el nivel de incertidumbre se garantiza con la organización de un torneo por zonas con ascensos y descensos de categoría ( $A, B$ y $C$ ), con lo cual, la competencia lleva a que cada equipo tenga su lugar de pugna y desafío, no solo en los valores extrínsecos del deporte (el ganar, la superación, el esfuerzo, el éxito deportivo, el campeonato o el ascenso de categoría), sino por los intrínsecos también (la búsqueda de la excelencia en el juego, la destreza, la habilidad y el juego limpio). De esta manera el tono en que se desarrolla el juego hace que este siempre resulte atractivo, no se vuelva monótono y mantenga el entusiasmo en los participantes.

No puedo dejar de señalar también que el hecho de la mediatización de los plazos para obtener un campeonato a lo largo de un torneo o una temporada de competencia, desplazan el placer del triunfo inmediato que podría obtenerse al término de un partido informal, a una satisfacción que tiene que ver con la identidad grupal y el prestigio de una tarea lograda en equipo y con un esfuerzo consecuente a la sumatoria de los esfuerzos progresivos a lo largo del año. Esto pone de manifiesto nuevamente la tensión existente entre la idea del placer y del trabajo donde la práctica, el entrenamiento y el esfuerzo constante en la tarea de equipo son necesarios para llegar a la cima o el éxito, emparentándose más con el mundo del trabajo que con el ámbito del regocijo del tiempo libre (Elías, 1996: 264-265). 
Al no interesar solo el resultado, siempre hay algo por lo que jugar y competir. Si bien en algún punto la búsqueda del placer en el componente lúdico y en el competitivo también es egocéntrica, personal, justamente la búsqueda de esos bienes internos del fútbol hace que los equipos y cada jugador en singular, aprecien la contienda deportiva, aun cuando no tengan mucho que ganar o perder desde la competencia, sí pueden hacerlo desde los otros valores que sostienen esta elección.

Cuando hablamos de la supervivencia del juego y del Torneo de Fútbol de Padres, también estamos hablando que los mismos participantes construyen a partir de la aceptación de diferentes reglas con las que se enmarcan los límites y posibilidades de la competencia. El fútbol como práctica deportiva popular viene a representar una cantidad de símbolos, imaginarios muy importantes para los argentinos. $Y$ su elección por este grupo de sujetos para su práctica tampoco es ajena a este paradigma donde el fútbol da cuenta de este patrón de elevada tensión de grupo, tanto en la cooperación y solidaridad como en la competitividad; manteniendo a su vez el menor daño físico posible entre sus participantes.

La elección de este tipo de competencia no es casual ni externa a los protagonistas. Ellos conformaron parte desde su origen del espacio, del escenario, del guion y de ser los actores protagonistas de la práctica que quisieron y quieren realizar. Se someten a las reglas y normas que quieren para esta práctica que sin duda refiere al control y preservación de los niveles apropiados de violencia (Elías y Dunning, 1996: 237-239) que permitan el desarrollo de una competencia viril, varonil, masculina; pero sin el riesgo de riñas, trifulcas y desmanes que suelen ocurrir en otras instancias competitivas de acceso y organización barrial.

Entre las motivaciones más importantes que aparecieron en las entrevistas y encuestas realizadas, el grupo de amigos, la amistad, el grupo, fueron de las más recurrentes y centrales para lograr plasmar la inquietud y el interés que devino en la realización de esta investigación.

Para iniciar el análisis en este aspecto creo necesario volver sobre el contexto identitario de la clase social a la cual estoy observando e interpretando. Configurado principalmente por sujetos de clase media/media alta para nuestros estándares de vida, profesionales independientes, comerciantes, universitarios, propietarios de casa y vehículos y con la posibilidad de pagar sumas moderadas y altas por la educación de sus hijos a instituciones educativas de prestigio en la zona. 
Aún dentro de este agrupamiento, pueden diferenciarse entre sí algunos equipos representativos conformados por grupos más o menos pudientes que otros, de los extremos que puedan hallarse en este agrupamiento. Partiendo de una misma escuela que tal vez presente equipos $\mathrm{A}, \mathrm{B}$ y $\mathrm{C}$, algún agrupamiento puede darse por la cuestión económica y otras veces por la conjunción de hombres mayores o más jóvenes, o bien por conocerse de antemano.

Ahora si la cuestión de la clase social no opera dentro de la competencia deportiva, sí lo hace desde la perspectiva de diferenciarse del otro. No hay manifestaciones abiertas de discriminación y cuando las hubo fueron rigurosamente sancionadas por la organización pero fueron aún más duramente castigadas internamente, por los protagonistas de los propios equipos ${ }^{15}$, si bien la participación está sesgada por la clase social a la cual pertenecen, los procesos de inclusión se hallan de manifiesto al haberse incorporado equipos de escuelas más periféricas que las iniciales, de ambos extremos del segmento original ${ }^{16}$.

La condición de admisión y permanencia está supeditada al comportamiento deportivo en todos los órdenes (acciones de juego, cumplimiento de documentación, horarios y demás detalles organizativos) y no por la procedencia del barrio o localidad o condición económica de sus jugadores. Así, en el torneo conviven equipos conformados por diversos orígenes de procedencia (siempre media y media alta), que si bien compiten, se respetan; apareciendo entonces fundamentalmente la condición igualadora de la práctica deportiva, más que la supremacía de clases y la lucha de poder que explica Bourdieu (1992), o cómo propone Messner (1992: 13) de resistencia de las clases subalternas a la dominación impuesta por rasgos hegemónicos culturales; como parte de las simbolizaciones que se representan en esta práctica.

Los ocupantes de un espacio deportivo intentan preservar su estatus y al mismo tiempo aumentarlo, conformando organizaciones que fortalezcan su identidad colectiva

\footnotetext{
15 Situaciones aisladas como golpes arteros, insultos, expresiones como "negro de mierda" o "gordo cheto y cagón" fueron sancionadas durante el juego con exclusiones temporarias y definitivas y con fechas de suspensión e inhabilitación a seguir jugando el torneo, al menos por esa temporada. También, cada equipo tomó acciones con los sujetos que reiteradamente incurrían en estos excesos, aduciendo que los dejaban siempre con menos jugadores y perdían puntos en la copa "Fair play".

${ }^{16}$ El Colegio Aberdare y el Colegio San Pablo de la localidad de Hurlingham, distrito lindante al este con Bella Vista son escuelas de elite; mientras que el Manuel Belgrano de José C. Paz distrito vecino al oeste de San Miguel y el Naciones Unidas de esta localidad, contienen una población de clara clase media trabajadora.
} 
(Rodríguez, Díaz, 2008) lo que impide que desciendan a categorías sociales inferiores, en un concepto de "cierre social" (Parkin, 1978). Para Lefebvre (1991), el espacio producido es un espacio conquistado y la propiedad de este espacio responde a una condición material propia de la modernidad, pero el concepto de apropiación de ese espacio sugiere una relación diferente al ocuparse mediante procesos más sociales que económicos, más simbólicos que materiales. La tensión por la ocupación de estos espacios puede verse en esta experiencia como la intención de otros equipos, Colegios y grupos de querer ser parte, de poder participar.

No se aprecian antagonismos manifiestos entre los extremos citados, no hay una puja especial por ganarle a los más adinerados ni un sometimiento ni disfrute particular por vencer a los más pobres. La condición de la competencia se enaltece en conseguir el triunfo por parte de los dos equipos con las armas leales y en todo caso por el sometimiento del buen juego, entendido como aquél estilo argentino ya mencionado en el Capítulo I. El descubrimiento de la interacción, el comportamiento, los discursos, de lo permitido y no habilitado, pasa por el reconocimiento de la palabra del otro y por tomar un camino que otros ya recorrieron. A su vez, los que concurren desde hace un tiempo guían a los nuevos adeptos en las artes y procedimientos considerados apropiados en este contexto. Cómo explicita Mac Intyre:

Entrar en una práctica, es entrar en una relación no solo con sus practicantes contemporáneos, sino también con quienes los han precedido en ella, en particular cuyos méritos elevaron el nivel de la práctica hasta su estado presente (1987: 256).

\subsection{La Salud en el Torneo de Fútbol para padres. ¿El Fútbol es una buena alternativa?}

Otro aspecto saliente de la indagación es acerca de las cuestiones de la salud que se ven imbricadas en el material relevado. Existirían diversas búsquedas relacionadas con el estado físico, la fortaleza, la fuerza y la virilidad que se pondrían de manifiesto en la práctica deportiva del fútbol. Como ya vimos en otro apartado, el futbol canaliza estas aptitudes y condiciones como ningún otro juego en nuestra sociedad. Sin embargo, otros estudios reflejan que no necesariamente es la mejor opción a la hora de elegir una actividad física sobretodo en la edad y condición de los participantes de este torneo. 
La confusión existente en nuestro medio entre ejercicio y deporte hace que los que recién ingresan a un plan de actividad física tomen caminos o decisiones equivocadas tan solo por no saber distinguir la diferencia existente entre ambos. Un importante porcentaje de participantes indica haber realizado controles médicos periódicos antes y durante el desarrollo del torneo, pero otros asumen que no lo han hecho y muchos otros que no se ejercitan ni se preparan para el acontecimiento deportivo del domingo.

El deporte, el fútbol en particular, posee una cualidad que lo hace poco aconsejable en una primera etapa del que se inicia o retoma un plan de actividad física. El fútbol impone reglas a las cuales los sujetos participantes deben adaptarse; de hecho muchos se integran a su práctica en este Torneo sin importarle mucho cuál es su historia médica, cuáles son sus factores de riesgo y qué grado de habilidades biomecánicas posee. Los jugadores deben correr detrás de una pelota, al ritmo de ella, deben inclinarse a ángulos no convenientes para su estado o el trabajo cardiaco debe responder al ritmo del deporte o del que le impone su contrincante, con el cual está participando.

El ejercicio, la preparación física, el acondicionamiento corporal tiene la cualidad de que se puede programar, dosificar y adecuarse a las características, necesidades y objetivos, es decir, el sujeto no se adapta al ejercicio, es éste el que se adecúa a él. La práctica del fútbol por sí misma no propone el límite, muchas veces invita a una dinámica difícil de sostener en forma común a todos los participantes.

Existiría en la práctica deportiva una redistribución temporal de los recursos (energía) normalmente utilizada para otros propósitos. (Shimtz, 1979: 123-126). Para David Sansone (1987: 37) el deporte resulta de un sacrificio ritual de energía física. Hay un exceso de energía voluntaria que se decide gastar haciendo deporte. Como ritual, presenciamos la cohesión del grupo, una canalización de la agresividad y una tendencia a la exageración, la estilización y la repetición. Podría interpretarse esta necesidad de depositar ese exceso de energía en la práctica deportiva del fútbol, como una de las razones que llama a los sujetos a participar de él. Tal vez no hallen en otras prácticas deportivas, la misma descarga, la misma intensidad física en las ejecuciones, pero a través de lo vivido y relevado en esta experiencia, creo que tampoco pueden o podemos, vivirlas con la misma entrega y apasionamiento.

Por otro lado, también está comprobado que quienes hacen actividad física envejecen menos (Ríos, 2008). El doctor Tim Spector y sus colegas del King's College de 
Londres, Inglaterra concluyeron en su estudio del caso de 2400 hermanos mellizos en las que analizaron los efectos del sedentarismo, que el decaimiento biológico puede retardarse 10 años realizando actividad física ${ }^{17}$.

Estos hallazgos subrayan la importancia de promover la práctica regular del ejercicio para retardar el envejecimiento y disminuir el riesgo de padecer enfermedades asociadas a la edad. La recomendación de realizar 30 minutos de actividad física de intensidad moderada al menos 5 días a la semana, para tener efectos significativos de bienestar en la salud. El reconocido Dr. Horacio Duchi, Profesor de Educación Física y docente formador de varias Instituciones de prestigio en la Educación Física argentina, clarifica algunos aspectos relacionados al envejecimiento y la práctica deportiva:

El envejecimiento se manifiesta en "una disminución progresiva y regular, con la edad, del margen de seguridad, de nuestras propias funciones, que parecen tener un ritmo de crecimiento y decrecimiento genéticamente programado, pero no obstante ampliamente afectado por las condiciones de vida, mucho más con las condiciones de trabajo de las distintas profesiones, que con la desigualdad de ingresos (Duchi, H.; 2006)

Dentro de las sintomatologías más evidentes de la senescencia (proceso del comienzo de la senectud, envejecimiento) es el deterioro del organismo en sus diferentes tipos de tejido: El tejido conjuntivo pierde elasticidad y se vuelve más rígido. En el aparato locomotor se produce descalcificación, falta de fijación del calcio y el fósforo y la progresiva transformación del hueso en una sustancia esponjosa (osteoporosis), acentuación de las curvas fisiológicas y riesgo de fracturas. Las articulaciones sufren la degradación y degeneración de los cartílagos articulares, inflamación de ligamentos y tendones aledaños. Debilitamiento de las propiedades del líquido sinovial y menor

17 Los investigadores se centraron en el análisis de los telómeros porciones de ADN que se encuentran en los extremos de los cromosomas y que se acortan cada vez que la célula se divide. Cada año que pasa, los cromosomas pierden en promedio 21 de las unidades que conforman los telómeros y cuando estos se vuelven demasiado cortos, la célula pierde la capacidad de dividirse. La comparación del largo de telómeros de los voluntarios agrupados en sujetos inactivos (16 minutos de actividad física semanal promedio); poco activos (36 minutos); moderadamente activos (102 minutos) y muy activos (199) dio como resultado que hombres y mujeres que eran menos activos tenían sus telómeros más acortados que sus pares, independientemente de su edad. Los sujetos más activos tenían los telómeros del mismo largo que los individuos sedentarios hasta 10 años más jóvenes en promedio. Esta diferencia sugiere que los sujetos inactivos quizás sean biológicamente 10 años más viejos que los sujetos más activos. 
producción del mismo provocando falta de lubricación y deslizamientos defectuosos, provocando desgastes de las caras articulares (artrosis y artritis).

Los músculos envejecen a partir de la pérdida del tono muscular, sobre todo en las grandes masas o raíces de los miembros. Se reduce la fuerza muscular, la resistencia, la rapidez y la coordinación de los movimientos, se producen modificaciones en la contractilidad y elasticidad; la fatiga aparece rápidamente por la disminución de la producción de energía, bajo deficiencias de las condiciones de oxigenación y la insuficiencia de regulación cardiorespiratoria.

El aparato cardiovascular se ve afectado a través del aumento de la presión sanguínea y la frecuencia cardíaca; la disminución del consumo de oxígeno y trastornos del ritmo cardíaco (arritmias, palpitaciones, soplos) y la disminución de la capacidad de flujo sanguíneo a través de venas y arterias (Arterioesclerosis).

También se produce un deterioro de algunas funciones cerebrales a partir de una disminución del número de neuronas, una reducción de la velocidad de conducción neuromotora (retardo sináptico); del consumo de oxígeno del cerebro y de su caudal sanguíneo. Se mantiene la comprensión, la capacidad del juicio, el vocabulario y los conocimientos generales. Se alteran la atención, la concentración, la memoria, la asimilación y la velocidad de reacción mental.

Desde este posicionamiento biologicista entenderíamos que la práctica del fútbol no sería precisamente beneficiosa ni apropiada para este tipo de sujetos de mediana edad, más allá de los gustos, preferencias y pasiones que ella despierta en nuestro país. Sin embargo, otras miradas de tipo socio antropológicas como la de Le Breton (2008: 143144) nos brindan nuevos elementos para justificar esta elección:

El hombre de la modernidad combate todo el tiempo las huellas de la edad y tiene miedo de envejecer por temor a perder su posición profesional y a no encontrar empleo o espacio en el campo comunicativo.

El envejecimiento es un proceso insensible, lento, que escapa a la conciencia porque no produce ningún contraste; el hombre pasa, suavemente de un día al otro, de una semana a la otra, mes tras mes, son los acontecimientos de la vida cotidiana los que dividen el paso del día y no la conciencia del tiempo.

Con una lentitud que escapa al entendimiento, el tiempo se agrega al rostro dejando, surcos y líneas de expresión, debilita los músculos, penetra los tejidos, disminuye la energía pero sin traumatismos, sin ruptura brutal. Durante mucho 
tiempo en la vida, la percepción es que envejecen los otros, nunca, uno mismo. El tránsito hacia la madurez y luego a la vejez, es un camino que se recorre a paso de hombre, cada día se avanza un paso sobre la ruta, pero la distancia parece larga e inagotable el trayecto que resta a cualquier edad. El tiempo inscribe su huella en la relación del hombre con su mundo. El rendimiento de una persona no se modifica de un día para el otro, ni su salud se altera de este modo, sino insensiblemente, sin golpes bruscos, es sobre todo el recuerdo el que evoca lo que el sujeto podía realizar sin problemas, poco tiempo atrás.

Mucho antes de reconocer su declinación en el rendimiento, aparece la necesidad de resistirse a él, de encontrar los métodos para continuar perteneciendo, de hallar la manera de seguir participando en ese medio, en lugar de buscar y encontrar los escenarios más convenientes y provechosos para seguir realizando actividad física saludable de acuerdo a su edad y su estado de condición física. La pulsión por continuar la práctica deportiva del fútbol entre estos sujetos, también está impulsada por esta necesidad seguir vigente, de sentirse que todavía puede desarrollar una actividad deportiva, tal vez no tan indicada para este momento.

Como la imagen del cuerpo se renueva sin cesar, refleja fielmente las aptitudes físicas del sujeto, acompaña sus transformaciones fisiológicas, el sujeto no tiene la impresión de estar envejeciendo. Todos nos asombramos cuando miramos fotos de hace algunos años. Cómo el paso del tiempo no es nunca perceptible físicamente, sugiere una sensación de inmovilidad. Se necesita un intervalo y un examen consciente para comprobar que el tiempo pasó y el cuerpo cambió. La imagen del cuerpo es la representación que el sujeto se hace del cuerpo, de su propio cuerpo; la manera en que se le aparece más o menos conscientemente a través del contexto social y cultural de su historia personal (Le Breton, 2008: 145) ${ }^{18}$.

\footnotetext{
${ }^{18}$ La estructuración del cuerpo estaría organizada por el entrecruzamiento de varios ejes: La forma (la integralidad de las partes como un todo, el límite con lo externo); el contenido (la percepción del cuerpo como un universo donde se inscriben sensaciones previsibles y reconocibles); el saber (el conocimiento de todos acerca del funcionamiento común y de las partes de todos los cuerpos) y el valor (la interiorización que el sujeto hace del juicio social respecto de los atributos físicos que lo caracterizan, lindo/feo; joven/viejo; alto/bajo; flaco, gordo). De acuerdo con la historia personal y con la clase social a en la que estructura su relación con el mundo, el sujeto se apropia de un juicio que marca con su impronta la imagen que hace de su cuerpo y de su autoestima. Estos ejes acompañan al hombre durante su existencia y van cambiando a medida que suceden los acontecimientos, que la vida pasa y con ella el proceso de envejecimiento. Esta imagen del cuerpo es como una vara con la que se evalúan las acciones que se llevaron a cabo y las que habrán de producirse, una medida de la relación con el mundo (Le Breton, 2008: 146).
} 
Estos componentes dependen del contexto social, cultural, económico en el que se desenvuelve cada sujeto, sin el cual no podría pensarse en la imagen del cuerpo, del mismo modo que en su identidad. Sin embargo, el registro del valor se presenta aquí en el punto de vista del otro, y moviliza al sujeto a tomar la iniciativa para verse y que lo vean, desde una óptica preferentemente favorable.

En este sentido, el proceso de envejecimiento tiene connotaciones negativas, ya que la depreciación de las posibilidades físicas puede traer sensaciones de decadencia y menosprecio personal, o bien, puede vivirse como el coronamiento de una vida acabada. Esto depende de la trayectoria personal, de los valores con los que convive, del sentido que le atribuye a sus actos, de la calidad y valoración que de ellos haga su entorno más directo (Le Breton, 2008: 147).

Lo cierto es que existe una búsqueda por sostener el mayor tiempo posible ese estado de satisfacción personal por el rendimiento físico. Esa necesidad de pertenecer al grupo de sujetos que sienten el placer de que su cuerpo continúe vigente en la disputa deportiva, se vea fuerte y vigoroso, atractivo y viril, sea valorado por los otros. Es esta valoración externa la que impacta sobre el sujeto para apropiarse de su satisfacción personal, mucho más que el propio reconocimiento de lo que puede y no puede hacer más por el paso del tiempo y el natural deterioro de sus posibilidades físicas.

Si bien estos son procesos lentos pero inexorables, la búsqueda por retardar la aparición de los mismos, parece ser otro elemento fundamental en la elección de esta práctica deportiva. A pesar de los riesgos asumidos como tales durante los partidos, son numerosas las lesiones artro-óseo-musculares (sobretodo esguinces de rodilla y tobillo, rotura de ligamentos cruzados, distensiones y contracturas musculares); manifestaciones claras de deficiencias cardiorrespiratorias, (fatigas, rostros enrojecidos prematuramente, dificultades para recuperarse, hiperventilaciones) que dan cuenta de la falta de preparación para la práctica deportiva: El deporte, como podemos ver puede ser un elemento beneficioso para nuestra salud pero el consejo es: "No haga deporte para ponerse físicamente en forma, póngase físicamente en forma para hacer deporte" (Saavedra, 1988). Indudablemente, la elección de esta práctica deportiva está asociada a otras búsquedas tal vez más profundas de indagar que el desarrollo de actividad física en pos de un beneficio en el orden de la salud física o de una mejora de la calidad de vida en una mirada más integral de las vidas de estos sujetos, considerando a la salud en un sentido más holístico, incluyendo aspecto de su vida psíquica y social. 


\subsection{Como operan las representaciones en la práctica deportiva del fútbol de padres.}

Existen varias contradicciones entre las expresiones vertidas por los sujetos, en tanto conceptos de salud, deporte, jugar, ganar, que considero fuertemente vinculadas a los efectos simbólicos y representantes que los que participantes de este Torneo de fútbol de padres depositamos en esta práctica.

De las estructuras definidas en el capítulo I, las más significativas a los efectos de ésta investigación, son aquellas vinculadas a las representaciones sociales en el deporte definidas por Denise Jodelet en tanto aspectos significantes de la propia actividad representativa y de las relaciones intergrupales. Ambos aspectos sirven al mismo tiempo para la definición de los grupos y para guiar sus acciones. Este grupo de padres en su conjunto, el de cada equipo y el de todos los equipos en general configura una representación social que le da forma, cuerpo y vida propia a la práctica del fútbol, ya que son ellos mismos quienes construyeron y le dan existencia, entidad y permanencia al Torneo.

La identidad colectiva se sintetiza en varias condiciones comunes a todos los participantes en tanto categorías ya analizadas (padres, hombres, masculinidad, segmento social y cultural al que pertenecen); pero las representaciones y significantes depositados en la práctica pueden diferir, de hecho difieren, de acuerdo a cada sujeto, pero en este caso en particular, interpreto que están sujetas a los vínculos y relaciones de sus participantes, más que a los intereses personales.

Así como las encuestas y entrevistas permiten apreciar la diversidad de intereses por la práctica, también destaca la fortaleza de la grupalidad, la amistad como una de las principales motivaciones que lo convocan. Ya destacada y analizada también la interacción de los sujetos y la tensión entre la dinámica y configuraciones de los mismos, creo que la representación y la significancia alojadas en el fútbol como práctica deportiva elegida por los sujetos, es clave para entender su supervivencia.

Ya en el Capítulo I analizamos la generación de una forma particular de jugar al fútbol en la Argentina que entre sus características principales señala el virtuosismo, la destreza con el balón, la espontaneidad y la imprevisibilidad de las acciones individuales y de conjunto; como así también la rudeza y el rigor por quitarle la pelota al adversario, la conquista del espacio y de la pelota, por la defensa de su valla impidiendo la marcación de goles del rival. 
Una lectura de las sociedades a partir del mundo simbólico del fútbol puede ilustrar algunos de los aspectos centrales de su cultura y del ethos nacional (Archetti, 1984).

Claramente asociadas a los conceptos de masculinidad dominante, estas características de juego del fútbol argentino hacen que este sea un escenario propicio para su manifestación, para el posicionamiento y conservación de un espacio netamente masculino, en tanto pertenecen a un orden y un mundo reservado a los hombres, ampliamente legitimada por la práctica deportiva. Estos sujetos, hombres, padres que comparten estas prácticas no eligieron el tenis, el basquetbol, la natación, el ciclismo, el atletismo o cualquier otra actividad o práctica deportiva que permitiera nuclearlos de alguna manera. La elección de la práctica del fútbol está sustentada además del gusto y la popularidad que este deporte tiene en nuestro país, por las simbolizaciones y representaciones que este despliega y lleva implícitas. Como sostiene Archetti (1984), "el fútbol aparece como una "arena pública" en la que se desarrollan alguno de los dramas de la sociedad y es por lo tanto un vehículo de su cultura”. En esta dirección es interesante preguntarse por su eficacia simbólica. Según David Le Breton "el simbolismo social es la meditación por medio de la cual el mundo se humaniza, se nutre de sentido y de valores y se vuelve accesible a la acción colectiva" (2008: 180).

Estos aspectos centrales de la práctica deportiva del fútbol abordada responden a los intereses comunes de todos los que los practican pero despojados del carácter populista que este deporte tiene en la Argentina, los padres participantes encuentran en este Torneo un marco de reglas, pautas y normas de comportamiento a las que adhieren y respaldan.

Existe también una mirada externa de aceptación, de aprobación que también es anhelada y buscada a través de la pertenencia a determinadas prácticas. ¿Cuáles son las prácticas sociales aceptadas para y por este grupo de personas?, ¿Qué tipo de actitudes y comportamientos hacen a las prácticas del fútbol más razonables, saludables, satisfactorias y significativas? No todos participan de manera exclusiva de la práctica del fútbol en este Torneo. Algunos que pueden hacerlo durante la semana en otros ámbitos, también lo hacen, de manera informal. Ahora bien, claramente no significa lo mismo para ellos jugar al fútbol en otros ámbitos, con otros grupos, que hacerlo los domingos, con los padres, en el Torneo de Fútbol para padres. El fútbol y el Torneo de Fútbol para padres 
en particular, encierran en sí mismo cierta ritualidad, cierta lógica que se repite en cada encuentro de domingo, en cada temporada y en todos los años en que se va desarrollando el Torneo. Si bien su adaptación también es permanente a las necesidades de sus participantes, la búsqueda de la misma emoción, de la misma descarga, de la misma pasión constituye buena parte del espíritu que da origen y pertinencia al Torneo.

Los sujetos no reaccionan nunca ante la objetividad de las cosas, sino que es la significación que les atribuye lo que determina su comportamiento. De una aceptabilidad social a otra ante el hecho consumado cada paso adelante modifica el umbral de tolerancia del campo social. Cada vez se producen más demandas individuales y se las favorecen, aunque las prácticas que las favorecen encuentren reticencias en el plano colectivo y perturbe el sistema de valores (Le Breton, 2008: 239). Claramente en línea con lo que declara el autor, el Torneo responde a las demandas individuales, pero también ha sabido aglutinar los intereses compartidos por un amplio grupo de personas. Y además ha aprendido a reproducir ciertas lealtades y moralidades muy propias del género. Este sistema de valores, o moralidades es otro de los aspectos claramente buscados por los participantes y cuidados en el desarrollo de la práctica deportiva; porque además saben que difícilmente lo encuentren en otro tipo de circunstancias competitivas relacionadas a la práctica del fútbol.

La reafirmación del uso de la regla, no para cumplirla a rajatabla, sino para aprovechar al máximo la vinculación con las normas que esta práctica social genera, aparece como una nueva representación de los códigos de aceptación y comportamientos deseables. El deporte se reconoce como un escenario donde encontrar una relación inteligente y satisfactoria para el uso de la norma, y sus protagonistas, siendo estos de diferentes sentidos y funciones en tanto diferentes niveles de comprensión y relevancia, tienen los conocimientos necesarios para apreciar sus reglas, sutilezas y matices más complejos. Entonces, la ética y la moral que se desprende de estas prácticas provendrían de la identificación e internalización de estas normas y este espíritu por parte de sus participantes.

La construcción de una instancia de participación deportiva en el fútbol donde la rivalidad no fluya hacia la violencia, donde la agresividad justa por la disputa de la pelota y los espacios conserve la demostración de la virilidad masculina, en donde la demostración de la habilidad y la destreza con el balón no implique el sometimiento y la humillación hacia el otro y la búsqueda del éxito y el triunfo no esté confinado a ganar el partido a 
cualquier precio, traicionando el espíritu del juego limpio y las artes de jugar buen fútbol (a la criolla, a la nuestra) no es para nada sencilla, y al mismo tiempo muy saludables y respetadas en tanto se constituyan en configuraciones y representaciones sociales que manifiestan el tipo y el modo en que estas personas quieren, prefieren y eligen jugar.

\subsection{Como se desarrollan las relaciones entre los sujetos participantes.}

La condición de la preservación del grupo es central para entender la continuidad de los equipos en el Torneo y la supervivencia del Torneo mismo. La mayoría de los equipos continúa con el plantel inicial que los originó como equipo, allá hace más de 13 años cuando empezó el torneo. Salvo alguna deserción por edad o lesión, los primeros equipos aún siguen jugando con sus jugadores iniciales y por supuesto nuevas incorporaciones que se van produciendo con los años. Varios de aquellos que por distintas razones ya no juegan pasan a tomar otros roles y funciones pero no abandonan el grupo y están presentes casi todos los domingos acompañando a su equipo. Delegados, directores técnicos, utileros y aguateros surgen al costado de la línea de cal en una actitud de pertenencia e identidad únicas. Otros simplemente pasan a compartir el rato con su grupo de amigos, disfrutan del momento y de la tensión existente en los partidos; son los que disponen de la casa para reuniones organizativas y encuentros informales; siguen siendo parte del equipo.

Este tipo de encuentros informales que se dan de manera aleatoria y espontánea en cada grupo y con una frecuencia no programada, resulta un verdadero momento de afianzamiento de las relaciones y vínculos originados en la pertenencia al grupo. Si bien no son en modo alguno obligatorias, casi nadie queda ausente de ellas; pertenecer al grupo es también pertenecer a su dinámica estructural. Muchos equipos se encuentran al menos una vez a la semana a "entrenar". Superando conceptos profesionales y científicos acerca del entrenamiento deportivo, ese momento del entrenamiento es la excusa para volver a verse y encontrarse con el grupo. No se hace la práctica deportiva en función del próximo rival, ni para el desarrollo de nuevas tácticas ni estrategias, ni para afianzar modelos o esquemas de juego o potenciar virtudes y habilidades propias. Siquiera se dispone de un espacio de juego similar al que se disputan los encuentros del Torneo, ya que la mayoría entrena en los clubes y canchas de futbol 5 y 7 de pasto sintético que abundan en la zona o en los patios y gimnasios que tienen y ponen a disposición las escuelas participantes durante el turno vespertino. El entreno en medio de la semana, la 
mayoría en miércoles o jueves como día preferido para hacerlo, convoca a los participantes a hacer el grupo, a construir la identidad del equipo, a conocer a los otros y a hacerse conocido por los demás.

Aquí se plasman las relaciones originadas en el punto en común de la práctica deportiva y en ella también aparecen el conflicto y el antagonismo producto de las interdependencias personales (Elías, 1996: 263). No todo es armonía y cooperación en un grupo, también hay luchas de poder, intereses y posicionamientos de privilegio que se van consolidando y erosionando con el tiempo. La llegada de sujetos más jóvenes a los equipos trae consecuencias gratas y otras no tanto. Ante las bajas producidas por lesiones o cuestiones de edad, y la incorporación permanente de padres a las instituciones escolares con la iniciación de los hijos a la escolaridad en el jardín de infantes, los equipos tienen un caudal muy potable de renovación de jugadores.

De todas maneras, obviamente no todos los nuevos padres se incorporan a la práctica (sería imposible albergar en el Torneo el alcance geométrico que tendría la multiplicación de participantes y de equipos en cada escuela); no a todos les interesa el fútbol, otros prefieren otros compromisos, pero hay algunos que sí quieren y pasan a formar parte de los equipos. Como aspectos positivos suelen mencionarse la renovación, nuevas ideas, gente fresca que pueda correr más, etc. Los más grandes suelen hacer los recibimientos e indicaciones de rigor de cuál es el espíritu reinante en el Torneo en general y en ese equipo en particular; si es que éste tiene aspiraciones competitivas o simplemente recreativas, más allá que cuando empiezan los partidos todos quieren ganarlos. La llegada de varios hombres más jóvenes a un equipo puede también empezar a correr esos objetivos iniciales cuando las situaciones de liderazgo comienzan a cambiar, las nuevas ideas comienzan a tener más fuerza y hasta la condición deportiva de los caudillos más veteranos empieza a ser cuestionada en tanto calidad, rendimientos individuales y los resultados de todo el equipo. El delicado equilibrio que se produce en las tensiones internas ${ }^{19}$ (Elías, 1996: 241-251) de un grupo en tanto los niveles de

\footnotetext{
19 "Si la búsqueda del placer (en el deporte) es egocéntrica, la búsqueda de la recompensa y la emoción es para los otros (espectadores, por ejemplo). Esto sugiere tres cosas: 1) Que estos objetivos surgen como meta principal del deporte dentro de diferentes patrones de interdependencia. 2) Que en determinadas circunstancias pueden ser incompatibles entre sí y provocar por tanto, tensión y conflicto. 3) Que la lista de polaridades interdependientes que intervienen en la dinámica de grupos deportivos puede ampliarse al menos con estas dos: a) la polaridad entre los intereses de los jugadores y de los espectadores b) polaridad entre "seriedad y juego" (Elías, 1996: 241-251). Yo interpretaría para el caso de estudio entre a) jugadores por individual y grupo y b) competencia y juego.
} 
agresividad y violencia con los de cooperación y solidaridad y el grado de competitividad deseable para el equipo por parte de sus participantes, redundará en el éxito y continuidad del equipo.

Este equilibrio debe estar sustentado en la búsqueda de objetivos comunes del grupo en total y de cada uno de los individuos, las personas que lo conforman. No olvidemos que en el deporte, en el fútbol en particular, las acciones articuladas que llevan a una misma meta resultan de la dinámica figuracional propia del juego, donde dichas acciones dependen de las decisiones, objetivos y motivaciones de los propios protagonistas.

Si bien es esta una práctica no profesional, con el paso del tiempo ha ido asumiendo rasgos y características de una seriedad y rigurosidad que ha sido búsqueda, interpretada e implementada por los mismos sujetos participantes y aquellos que los representan en la organización.

Además, como toda organización social, de algún modo el Torneo mismo; cada institución educativa en su grado de representatividad en uno o más equipos y cada equipo en su interior propio ha generado cadenas de interdependencia más amplias y diferenciadas. Esto trae aparejado un nuevo equilibrio de fuerzas y de poder en cada una de las instancias ya que, quienes realizan papeles especializados dependen de otros y pueden ejercer por tanto un control recíproco (Elías,1996: 264).

Así, los organizadores solicitan documentación que garantice la legalidad de la inscripción de los jugadores, es decir, que sean ciertamente padres de niños que asisten a la escuela a la cual representa determinado equipo. Los delegados confeccionan las listas, la institución escolar las avala con sello y firma de autoridad institucional y cada padre acerca el certificado de su hijo en calidad de alumno regular de dicha escuela. Los jugadores de otros equipos pueden reclamar por las vías adecuadas a la organización si saben o sospechan de alguna irregularidad de inclusión de algún jugador. El mecanismo de control se activa inmediatamente en el sentido inverso por los mismos protagonistas.

En el campo de juego, las interdependencias de los sujetos y la especialización de funciones también genera campos de poder y control recíprocos. La coordinación de acciones defensivas como por ejemplo a partir de un tiro libre a favor del rival desactivar la situación de peligro adelantando la línea defensiva en el momento oportuno para dejar en off-side a los atacantes rivales necesita de una acción mancomunada de sus 
protagonistas que debe ser indicada por alguien. Ese alguien por lo general es el "líbero", "el último hombre", el "2", quien marca la autoridad de ese segmento de la cancha y a quienes sus compañeros de línea obedecen, Depositan en él el liderazgo de las funciones defensivas, reciben sus indicaciones, estímulos y también los retos y reprobaciones cuando a su criterio no realizaron las acciones pertinentes.

Esta configuración pareciera dada por la lógica del juego del fútbol mismo y de la práctica del fútbol argentino. Sin importar tanto el dibujo táctico al cuál se avenga cada equipo, si es que tiene alguno, básicamente se tiene por estructura tácita que atrás (en la defensa) haya uno grandote que grite y pegue; despeje el peligro como fuera, no se equivoque y no tenga contemplaciones con el rival si es necesario En el medio (la línea de los volantes) tiene que haber uno que ordene, de buen pie y que distribuya el juego, pero otro que marque con dureza y firmeza a los rivales; y adelante (los atacantes) que corran y la metan en el arco.

La dinámica de los agrupamientos y reagrupamientos de los jugadores en un partido de fútbol es elástica y variable y siempre interdependiente e inseparable entre ellos, de ambos; esa dinámica es el juego (Elías, 1996: 234). Unos y otros respetan esta relación de roles y funciones en el equipo y quienes entran a jugar en esos puestos saben que se espera de ellos, aun cuando por alguna razón (lesión, suspensión) deba ocupar ese lugar sin ser su especialidad, sin tener las mejores aptitudes para ese puesto. Debe transformarse y cumplir ese rol y jugar como si supiera hacerlo. Cuando ingresa sabe que debe realizar determinadas acciones y que intentará hacerlo lo mejor posible y que será disculpado por sus compañeros si no lo logra del todo exitosamente:

- "Que querés...si no es delantero como querés que haga goles"

- "en el medio se siente perdido"

- "ahí no puede jugar si no tiene marca"...

Estas son sólo algunas de las manifestaciones recogidas que así lo demuestran.

Así mismo aparecen interjecciones reprobatorias cuando las cosas no salen bien, pero cada uno defiende su condición y habilidades para su puesto desde la postura de sus condiciones y habilidades para el mismo: Cuando hay un reclamo por un error defensivo, sobre todo si este error concluye en un gol del adversario, los delanteros no 
suelen reclamar a sus compañeros y cuando lo hacen son rápidamente censurados por los demás:

- "Vos andá adelante y tratá de meterla!"

- "Vos no hablés que ya te comiste como tres goles"

Rara vez, los delanteros son interpelados por sus yerros, entendiendo que la misión de hacer goles es más difícil que la de impedirlos. Más bien se los alienta a que en la próxima oportunidad van a tener mejor suerte. $\mathrm{Y}$ a los del medio se los incita permanentemente a no decaer en la intensidad del juego, cuando aparecen las señales de cansancio son los primeros que permiten el ingreso de otro jugador con nuevos bríos y energía. Dentro de la plantilla de los equipos, la mayor cantidad de jugadores se adjudican el puesto de volantes, dicen:

-"yo juego en el medio, si es para correr...corro!"

-“jugá en el medio pero meté y meté pata eh!"

-“cualquier "picapiedra" puede jugar en el medio"

Los roles y funciones dentro del campo de juego, en el partido mismo pueden cambiar no solo en función de las acciones del propio equipo sino en las que presenta el rival. De hecho deben concebirse e interpretarse como una figuración de ambos equipos y no de uno solo (Elías, 1996: 232). El constante agrupamiento y reagrupamiento de los jugadores durante la dinámica del juego dependiendo de las características que tenga ese partido en particular y la de los equipos que se enfrentan, suma atractivo a la incertidumbre del resultado.

A pesar de disputarse enfrentamientos de fuerzas y habilidades relativamente parejas, cuando un equipo comienza a ejercer una supremacía en el juego sobre el otro, estas relaciones e interdependencias, y la especialización de funciones pasan a otro plano y aparecen otras acciones vinculadas más al cooperativismo y a la solidaridad: atacantes, delanteros y volantes de creación que deben ejercer acciones defensivas porque su equipo lo precisa al verse desbordado por el avance del adversario. $\mathrm{Y}$ por el otro lado, defensores que pasan al ataque para empujar y forzar la caída de la valla rival, al ver que los que están para cumplir esa función no lo logran.

Los equipos pueden verse rotulados o estigmatizados por este tipo de acciones: 
- "estos son pecho fríos"

- "vamos para adelante que no bancan el resultado"

- "se paran todos atrás y no le entramos más"

Considero que en mucho dependen de los tipos de vínculos y relaciones que se hayan sujetas dentro del grupo para el éxito de estas acciones.

La posibilidad del grupo para poder interactuar no solo en el juego sino a partir de las variables dinámicas que en él se produzcan tendrán que ver entre otras cosas con la rigidez y elasticidad con la que puedan manejar sus relaciones personales, las cosas que se puedan decir, lo que estén dispuestos a dar por el otro, la disponibilidad corporal y el espíritu de identidad con el equipo. La tolerancia de recibir hasta el insulto de un compañero al aire, es decir para todos en general y hasta para alguno en particular, será posible en tanto la figura de este jugador esté legitimada por el propio equipo. No es igual recibir la arenga del capitán, del más viejo, del que más experiencia tenga en el fútbol, que recibirla de uno más nuevo, más joven o de menores habilidades deportivas. Los equipos que se conocen desde hace tiempo y sus relaciones interpersonales están bien aceitadas son más permeables a estos cambios

La imagen del capitán, referente o líder del grupo en estos casos es fundamental, sea para tranquilizar, moderar a sus compañeros como para alentarlos, arengarlos y hasta maltratarlos verbalmente. Debe hacerse sentir y notar posicionado en este lugar de privilegio ganado, permitido u otorgado por el grupo, porque, al fin de cuentas, es el líder.

Muchas veces las cuestiones del liderazgo en el grupo también están repartidas y eso es muy saludable porque se reparten las máximas responsabilidades de acuerdo a lo que el grupo necesita y no le caen todas a la misma persona, de manera tal que lo agobien. Así, aparecen roles como el del delegado para la cuestión organizativa, representatividad del grupo en reuniones, tesorería, etc. El liderazgo de la parte social, reuniones informales, celebraciones, fiestas, etc. $Y$ el liderazgo deportivo, el de adentro de la cancha y el de afuera, si es que hay alguno que funcione como una suerte de director técnico, convoque a los jugadores, realice los cambios, inclusiones y exclusiones del equipo y marque los momentos y esquemas tácticos de juego.

La relación de fuerzas y de poder de estos líderes también es delicada y cuando es buena se traslada a un estado de bienestar interno del grupo que se lleva a cualquiera de 
las instancias mencionadas. La palabra de todos ellos es respetada aunque se mezcle o aparezca en el contexto en el que no es su representatividad. Su opinión está legitimada por su acción y trayectoria en cualquiera de los otros aspectos, todos saben que es positiva y lo hará para el bien del grupo. Los líderes y referentes del grupo deben permitir a todos la oportunidad de expresarse, participar activamente en todas cuestiones pertinentes y cada integrante puede y debe encontrar su momento y modo de participación grupal así como encuentra un lugar y puesto para jugar en el campo de juego.

La disponibilidad corporal también juega un papel importante en tanto que es lo que puede hacer para el equipo. Esto se vio reflejado en las encuestas y entrevistas cuando mencionaron que fueron cambiando de puestos (sobre todo aquellos que están en los equipos desde el comienzo de su formación) por razones de necesidad, sanciones o lesiones de compañeros, ausencias y por las propias restricciones que aparecen con el paso del tiempo:

- "yo jugaba de wing, pero ya no corro como antes"

- "ahora juego paradito en el medio"

- "me quedo arriba de pesquero, alguna voy a agarrar"

Cuando el reconocimiento de la disponibilidad corporal propia y ajena se transparenta, se legitiman todas las acciones que sobre estas suceden. Entonces quienes en algún momento eran figuras indiscutibles en el equipo, pueden dar paso a otros que se incorporan con las mismas o mejores aptitudes de la actualidad deportiva del sujeto. Pueden permitirse jugar solo un tiempo, jugar en otras posiciones más aliviadas, ser más permeables a las disculpas y a la posibilidad del error.

Jugar al lado de quien sabe, y todo el grupo sabe, que ya no es el mismo de antes, supone en todos los integrantes de ese momento del equipo, un sobresfuerzo para poder cubrir lo que este sujeto ya no hace, correr más, saltar más, jugar con más fluidez, etc. Necesita que los otros respondan por él, corran donde él no corre, salten donde él no salta, ofrecerse con más opciones de pase ante su falta de reacción, velocidad y coordinación rápidas. Cuando es una persona reconocida por su paso en el Torneo de tantos años, es muy particular como también influye en el comportamiento de los rivales, al menos para quienes tienen un recorrido similar. Es asistido si se cae o golpea, 
esperado sin prisas si va a buscar la pelota a un lateral, aplaudido y saludado por su ingreso o salida del campo por sus compañeros, rivales y árbitros.

La identificación con el grupo es clave para el sostenimiento de los equipos. La mayoría de los mismos como dijimos, mantiene sus planteles originarios con las incorporaciones y bajas lógicas del paso del tiempo. En algunos Colegios que son representados por más de un equipo en el Torneo, es decir que tienen equipo " $A$ ", " $B$ " y "C", algunos decidieron pasarse a otro entendiendo que su disposición corporal no estaba a la altura de los objetivos competitivos del equipo que formaban parte, y pasaron por algunas temporadas al "B" o al "C". Al cabo de una o dos temporadas varios volvieron a su grupo de origen y llevaron con ellos alguno de los nuevos conocidos que aspiraban situaciones de juego más competitivas.

Cada equipo y grupo construye un entramado social que permite estas fluctuaciones y migraciones donde pertenecer o no pertenecer al grupo pasa por una decisión evidentemente personal, donde el sujeto debe hallarse cómodo y disfrutar del deporte y de la compañía de todos los que forman el grupo. Las salidas de las personas siempre generan movilizaciones internas dentro de los grupos, ya que siempre esta persona ha generado lazos más cercanos con unos y otros y si se lleva a alguien más, aparece como una desestabilización interna. La llegada de otras personas provoca una acción compensatoria, pero siempre es nueva y la percepción de nostalgia y añoranza del que estuvo y se fue permanece. Los efectos son distintos, si el que se va, pasa a formar parte de un equipo de otra escuela. Esto es más común que lo que a priori podría creerse, ya que hay algunos movimientos de pases de alumnos de una Colegio a otro (por conveniencia o acontecimientos familiares, separaciones, divorcios, mudanzas); la condición de pérdida de identidad con el Colegio se percibe casi como una traición y no se tolera de la misma manera que en el caso anterior.

Los procesos de identificación con la Institución escolar son importantes en tanto mejoran la relación de las familias participantes con la misma. En los equipos conviven padres cuyos hijos concurren al mismo año y curso y entonces allí se afianzan los lazos entre los hijos y las familias. Comparten reuniones y salidas más íntimas por fuera del ámbito grupal del equipo de fútbol, se pasan libros y carpetas, uniformes que ya no les quedan a sus hijos, datos sobre maestros y profesores que pueden tener los hermanos más chicos o los hijos de otros padres que juegan en el equipo. 
A partir del encuentro y de conocerse en la participación del Torneo de Fútbol, hay padres que desarrollaron nuevos emprendimientos laborales aunando saberes profesionales, capitales, talleres, instalaciones y demás insumos. Otros salieron en ayuda y sostén de quién necesitó una mano en momentos críticos de la economía argentina, allá por los años 2001 y 2002 y hasta se lograron vínculos y asociaciones exitosas entre padres de diferentes escuelas, hoy compañeros y socios de alguna empresa.

La reiteración y frecuencia del encuentro deportivo establece lazos afectivos asociados a la búsqueda de la situación placentera del encuentro. La sensación de disfrute del encuentro deportivo propone repetir la experiencia una y otra vez. Lógicamente los resultados positivos desde el punto de vista de ganar los partidos, de triunfar en la contienda deportiva, consolida estos lazos. Si bien lo expresado por los sujetos protagonistas es que vienen a jugar, también es cierto que si los resultados acompañan la asistencia es casi perfecta, y es más, algunos "desaparecidos" del equipo comienzan a regresar a la práctica convocados por los triunfos de su equipo. Así también, aquellos que padecen malas campañas, rachas de derrotas, ven disminuidas sus plantillas de jugadores que acusan lesiones y compromisos sociales que nunca aparecerían como impedimentos si la realidad deportiva y los efectos de los resultados fueran otros.

Las relaciones estructurales de los grupos se ven claramente afectadas por la práctica que los sustenta. La configuración de los grupos participantes sin duda es muy particular de cada uno, y no es interés de este estudio adentrarse en el funcionamiento de cada uno de ellos, simplemente doy a conocer algunos rasgos característicos y comunes que se dan a partir de la práctica deportiva y de aquellos particulares que me permito conocer y compartir a los cuáles considero novedosos y valiosos en tanto emergen de esta práctica.

El carácter de participante de esta práctica me permite revalorizar los vínculos alcanzados con padres de la misma institución a la cual represento, pero aún más, puedo capitalizar las relaciones y vínculos alcanzados con personas de otras instituciones a las cuáles nunca hubiera podido conocer y nunca me hubieran conocido sino hubiésemos formado parte de esta experiencia 


\section{Reflexiones Transversales Finales}

La profusa búsqueda bibliográfica de literatura de contenido antropológico, sociológico, psicológico y educativo relacionada con las prácticas sociales, culturales y deportivas me llevó a reflexionar acerca de cómo los sujetos en la actualidad se mueven al ritmo de sus problemas, artificiales o simbólicos, creados y recreados permanentemente. Precisamente, el deporte y el fútbol constituyen claros ejemplos de ello. La distancia con el objetivo a lograr, la brecha entre lo que se busca alcanzar y las capacidades necesarias para alcanzarlo, el objeto y el deseo de conseguirlo, son vitales para comprender la importancia y significado que cada comunidad le otorga a la práctica del mismo fútbol; pero, ¿es el mismo fútbol el que se juega en cada sitio, lugar o contexto? ¿Son los mismos intereses los que convocan a su práctica? ¿Da lo mismo con quien jugamos, quienes son nuestros adversarios y quienes son nuestros compañeros de equipo? Las adaptaciones a las reglas y dinámicas de los deportes transcurren por la disminución del número de participantes y la reducción del tamaño de los espacios de juego -no siempre bienvenidas por todos los participantes, como en el caso estudiadobien por el cambio de reglas obsoletas por otras que permitan una mayor agilización del juego, por la aparición de acciones espectaculares y de nuevas habilidades y destrezas generando nuevos bienes internos a obtener-; o también en la búsqueda de nuevos y dignos oponentes para lograr la apropiada competencia -en una actitud leal y cooperativa del deportista-, renovando constantemente este desafío en la competencia. De esta manera es que se desarrolla en la mayoría de los juegos y deportes creados por los sujetos, el objetivo de lograr el desafío justo y adecuado.

Cuando podemos crear juegos, deportes y todo tipo de actividades y retos, suplimos de manera muy eficaz problemas impredecibles y riesgosos de la vida cotidiana, laboral, profesional y hasta amorosa; por otros más esperables, manejables y más fáciles de controlar. La indagación sobre las prácticas corporales permite darle nuevos sentidos al juego y al jugar cuando nos permitimos superar la mirada superficial del cómo se realizan estas prácticas, sus reglas, competencias, organizaciones y formatos; y de ellas, nos disponemos a analizar experiencias buscando razones, relaciones, escenarios, personas, motivaciones que testimonien como se viven estas experiencias, qué fenómenos suceden entre quienes intervienen en ellas y, en el caso particular de este estudio para quien escribe, ser participante de la misma. 
Un primer paso para la interpretación de estas prácticas es tratar de desnaturalizarlas, de desafiarlas y problematizarlas. De la observación en el campo y de la observación participante se desprenden discursos dominantes y a la vez contradictorios acerca de lo que está bien decir y hacer, contra lo que en realidad sucede. Casi una constante en el análisis de encuestas y entrevistas, apareció está suerte de "incoherencia" entre lo dicho y lo que realmente se hace, por lo menos en términos lineales. Lo considero por un lado constitutivo de los modos de subjetividad moderna, pero también -y específicamente referidos al objeto de estudio- una parte de la misma configuración social emergente, donde está "bien visto" hacer actividad física, sin importar tanto cómo, ni bajo qué cuidados. Por el contrario, sí importa cuál deporte o actividad física se realiza, con quienes (en relación al contexto socio cultural de los participantes) y dónde (el espacio, el lugar). Para decirlo en los términos nativos, "está bien contar que hago deporte, está mejor decir que juego al fútbol" no cualquier actividad deportiva: El fútbol como deporte popular, de roce, de contacto físico, de demostración de hombría y virilidad, como un fuerte acercamiento hacia este tipo de prácticas más reservadas a sectores sociales más vulnerables, desplazando otras elecciones posibles y más comunes de prácticas deportivas identificadas con las clases medias como el tenis, el ciclismo y la natación, por ejemplo.

Por decirlo en primera persona, es apropiado decir que participo de un torneo, no de un juego espontáneo el fin de semana. Que formo parte de un equipo, que represento al colegio de mis hijos. Que estamos inscriptos en un Torneo de carácter anual, que está organizado, que tiene un fixture, canchas reglamentarias, con árbitros y jueces, muy cerca de las condiciones profesionales de competencia donde se resguardan situaciones de orden, ley y legitimidad. En este sentido, interpreto que es mucho más importante decir que el torneo se circunscribe a padres de Colegios de la zona, ya que esto define a la categoría de personas con las que se realiza el encuentro y produce el efecto de aceptación y pertenencia. Existe el interés -interpretado como necesidad- de sentir que somos parte de algo más importante, de un grupo, de un objetivo común que supera el esfuerzo individual y nos trasciende tras los colores que representan a una institución, donde las camisetas llevan los colores que identifican a la misma, el escudo o logo y hasta la dirección web impresa.

Este discurso es el aceptado y legitimado en tanto precisa la validación y la valoración de los otros, del Otro -con mayúscula, en tanto cultura-: no solo de sí mismo 
sino también de los demás. De los que son parte de la práctica misma y del contexto social más íntimo de cada uno de los sujetos participantes. La identificación con las pautas de conducta y comportamientos, la aceptación de determinadas reglas y valores también forman parte de lo que socialmente está permitido y lo que no. Y de lo que está bien hacer y decir y de lo que no es apropiado o correcto para este segmento sociocultural.

Considero que el cuerpo y el uso que los sujetos puedan hacer de él y lo que se conoce comúnmente como su "estado de condición", en tanto manifestación de algún modo de salud -no solo en concepto de ausencia de enfermedad, sino a partir de una mirada más holística e integral de los aspectos que complementan y constituyen la idea de salud y calidad de vida de las personas-, promueve aquellas situaciones que permiten el desarrollo de una práctica deportiva, y a partir de ella, una interacción entre los sujetos fluida. Encuentro en esto una referencia simbólica muy representativa para ciertas categorías sociales, en especial para el caso estudiado. Las personas que viven en el campo o los trabajadores manuales y operarios -por el tipo de tarea que tienen, el desgaste y el cansancio ocasionados- carecen del tiempo, del interés y de los recursos necesarios de ver a su cuerpo como un objeto de valor social. Su interés por la práctica deportiva supone otros significantes y representaciones más asociadas al divertimento, el pasatiempo relajado y la continuidad de prácticas tradicionales. Son los profesionales, las clases medias y privilegiadas, las que sienten inclinación por valorizar la forma y el bienestar físico, preocupadas por moverse para encontrar una vitalidad desvirtuada por el sedentarismo y la falta de actividad física. Procuran transformar el agotamiento ocasionado por los nervios o el stress laboral, por el cansancio "sano", admitido en su esfera social, por la fatiga muscular a raíz de la práctica de actividades físicas. Los sujetos en la actualidad y de este segmento social estudiado y definido como de clase media y medio-alta para nuestros estándares de vida, cuida su aspecto y valora a su vez, que los demás también lo hagan. Necesita de un ambiente y de una mirada externa que lo apruebe, le pide al cuerpo una mejor postura, sensaciones placenteras, eficaces, vigorosas y combativas pero flexibles y resistentes a la vez.

Si la actividad física es un componente central en las formas de ser modernas, en tanto cuidado de la salud, contribución a los hábitos de vida saludable, al desarrollo de aprendizajes, al fortalecimiento de vínculos y a la consolidación de valores, también es porque el ejercicio de éste derecho constituye la elección de los sujetos, a encontrar los 
escenarios más apropiados para el desarrollo de sus deseos, en particular en los adultos con capacidad y poder en la toma de decisiones sobre ellos. En este sentido, el caso estudiado permite legitimar la práctica deportiva de fútbol de estos hombres, como construcción propia pero también como referencia del consumo simbólico de los deportes masivos y populares, por parte de la clase media.

Apoyándome en el concepto de masculinidad desarrollado anteriormente, creo sumamente apropiado este espacio que tienen los padres, por la oportunidad que les brinda de exteriorizar también sus emociones y sentimientos, sentidos generalmente subordinados por las condiciones sociales de género. Rodeados del anonimato el cual también prefieren, al pertenecer a un grupo donde pueden reír, abrazarse, gritar, insultar, temer, agredir y otro tipo de manifestaciones muy restringidas para los hombres en el ámbito laboral, productivo, social y hasta familiar. El mandato social sobre el género masculino, si bien está cambiando (como cambia el constructo social actual cada vez de manera más dinámica), todavía condena la demostración abierta de esas manifestaciones, pero las habilita en el contexto deportivo. Como diría Bourdieu (2000), los hombres están condenados a ser machos, condenados a reproducir su rol de dominantes, reproduciendo la idea de que son dominados por su dominación (cf. Galak, 2010; 2015).

En la recuperación de espacios y escenarios donde el cuerpo sea la manifestación visible de una persona vigente, vital, próspera, muy masculina y viril, donde se desempeñe con desenvoltura y elegancia, con eficiencia y destreza, con la vigencia de sus atributos juveniles, responde a los nuevos tiempos y mensajes que se imponen desde la lógica del varón. En este sentido, las prácticas corporales se ubican en un lugar de privilegio en el que aparece la necesidad del hombre en la lucha por destacarse entre la individualidad y la grupalidad por un lado, y el juego de los símbolos y significantes que él mismo privilegia y que agrega, en la elección de la actividad deportiva que va a realizar, un condimento social fundamental. El campo del deporte permite la realización de este deseo y de esta pulsión de nuestro tiempo.

La profunda individualización y personalización en la que hoy se sumergen la mayoría de las configuraciones relacionales de los sujetos en los diferentes ámbitos, no significa un movimiento hacia la independencia o libertad de los mismos, sino que estas prácticas y discursos se realizan bajo el control de una variedad de valores al mismo tiempo común y diferencialmente compartidos y reflejados por los distintos grupos 
sociales: la búsqueda de la juventud permanente, la buena salud, la vitalidad y el vigor físico, son indicadores sustanciales de nuestra realidad que la publicidad y los medios de comunicación no cesan de aturdir con sus mensajes y anuncios permanentes, y así entonces proliferan los cuidados, la búsqueda de emociones, las tentaciones y la necesidad de correr más allá el límite de la madurez.

Cada vez más difuso este límite, persiste el discurso por encontrar oportunidades laborales donde el trabajador disfrute de la tarea en la que se desempeña y por la cual invierte la mayor parte de su tiempo. Sus espacios de formación y capacitación para el puesto deben premiar el esfuerzo en pos de una condición de trabajo más relajada, supuestamente de menor esfuerzo y que posibiliten instancias de mayor control y supervisión. Mientras que por otro lado, la búsqueda de emociones y riesgos en el ocio y en el disfrute del tiempo libre nos lleva a transitar experiencias que cada vez más se ajustan a la seriedad, la rigurosidad y la creación de nuevas obligaciones y responsabilidades y se alejan de la relajación y la recreación. La invitación a la práctica deportiva informal, espontánea y aleatoria da paso en preferencia a aquella sistémica, organizada, frecuente, con normas, reglas, equipos, camisetas, árbitros, premios, medallas, ascensos, descensos, triunfos y derrotas. Eso sí, todas moderadas por las restricciones civilizadoras de nuestra sociedad, funcionando de alguna manera, como compensadoras de lo que nos permitimos en nuestra vida corriente.

Tal vez lo más novedoso de la experiencia investigada es la gestación, la creación de un propio modelo que se ajusta a los intereses, necesidades y finalidades de sus participantes, distinguiéndose en ella la convivencia de varias concepciones destinadas a la ocupación apropiada del tiempo libre. Ni una ni otras son estrictamente antagónicas ni complementarias. Me atrevo a decir que conviven en una configuración social que se acomoda permanentemente a estos tiempos. Que aparecen como bien vistas, saludables, progresistas, ideales a alcanzar por estas comunidades sociales que tienen acceso a determinados niveles de estudios, ocupaciones calificadas y tienen la posibilidad de elegir este tipo de espacios para la práctica deportiva. Si en el modelo de la práctica del deporte sustentado en la búsqueda de la excelencia, los valores y los bienes intrínsecos de juego, lo que interesa es el desafío, el reto: lo que representa la competencia debe ordenarse en un formato de principios que regulen la rivalidad y la disputa por el triunfo y además obligue a los participantes a respetarse, observando los valores, tradiciones y excelencias de ese deporte. 
Estos valores y principios están condicionados, al menos parcialmente, por la manera en que se conduce y organiza el deporte en cada contexto en particular, siempre ligado a los sentidos que giran en torno a los deportes profesionales. El comportamiento de los jugadores en el campo de juego es testimonio de esos valores, realzados y profundizados en este caso por la función paterna de referencia, de autoridad, de respeto, y cuidado de los demás. En relación al caso estudiado, claramente los sujetos que participan de la práctica, comparten y admiten los valores relacionados con el deporte que quieren jugar, con la manera en que quieren jugar al fútbol: los cuidan, los resguardan, rechazando actitudes y comportamientos reñidos con la lealtad deportiva y las malas artes en el juego. La conformación de cada uno de los equipos, de cada grupo en sí y de la totalidad de padres participantes, propone cierta unificación de ideas, objetivos y propósitos en búsqueda del bien común.

La consolidación de los grupos está fuertemente arraigada a condiciones simbólicas y a la construcción plural de las representaciones sociales que comparten. Esto favorece la comunicación, la integración e inclusión de nuevos adherentes, la proyección de relaciones y vínculos entre los participantes, más allá de los equipos a los cuáles representen, desconociendo situaciones de rivalidad deportiva. Lo que da sentido al desarrollo de esta práctica deportiva no es ganar el partido de la fecha, no es salir campeón de la temporada, ascender de categoría o mantenerse en la que está jugando. Interpreto que existe algo superior que impulsa a revivir una experiencia placentera sustentada en la participación colectiva, contenida en la visión compartida por el estilo y tipo de competencia elegida para realizar, privilegiada en la posibilidad de adaptación permanente de sus formatos y escenarios, lo cual devuelve mucho más que el cansancio y la fatiga muscular, corazones agitados y camisetas transpiradas, la euforia del triunfo y la tristeza por la derrota. Recupera un conjunto de situaciones y emociones que los sujetos viven en términos no acabados cuando son espectadores o consumidores del deporte, mientras que esta experiencia los hace protagonistas, actores de una propia realidad cargada de pensamientos, fantasías y símbolos, pero también impregnada de valores y virtudes de una masculinidad común y compartida, la de ser padres.

La amistad, el compañerismo, el grupo, el equipo son entidades que aparecen al mismo tiempo como figuras, representaciones y significantes que movilizan a estos hombres a repetir el momento, a cuidar y sostener un espacio que habilita vivencias manifestaciones y búsquedas, descubriendo lugares y costados personales que 
cotidianamente no se permiten mostrar en los ámbitos relacionales, laborales, profesionales, de estudio o familiares; abriéndose paso hacia nuevos caminos y puertos entre las personas que de no mediar el encuentro deportivo, hubieran sido mucho más difíciles de hallar.

La preferencia durante tantos años en la elección de este torneo y no de otros, la permanencia de los grupos casi sin modificaciones en las plantillas así lo demuestra, como la creciente inscripción de nuevos equipos e instituciones que procuran el mismo estilo de competencia deportiva. La práctica deportiva los nuclea, los aglutina, pero el sistema competitivo del torneo no los divide, no los aleja. Pudieron incorporarle a la práctica deportiva significaciones propias y representativas que promueven y producen nuevas y variadas interacciones sociales por dentro y fuera de la misma participación. Han sabido rescatar lo mejor de la práctica y la práctica ha permitido aflorar lo mejor de ellos en pos de objetivos comunes mientras estos están siendo construidos, objetivados, modificados por ellos mismos.

Si todos los actores que de alguna u otra forma participan del mundo del deporte jugadores, entrenadores, equipos técnicos, periodistas y simpatizantes-interiorizan éticas asociadas a los deportes y las explicitan permanentemente, cada uno en su modo de participación, conformarían un escenario donde podríamos aprender a enfrentar y responder a los desafíos que las prácticas deportivas tienen en sí mismas y en los que llegamos a apreciar e identificar principios y virtudes que su práctica requiere. $Y$ si estas acciones se desarrollaran en los más diversos contextos, en todas las edades, en cualquier disciplina deportiva, entonces la enseñanza en valores, su incorporación y adquisición sería posible aún en edades adultas y en nuestro caso de estudio, el deporte y el fútbol, precisamente una instancia y oportunidad únicas para hacerlo.

La recuperación del espacio lúdico, del espíritu de pertenencia a un equipo, de la práctica deportiva y de la representación de su masculinidad, hacen del espacio generado por el Torneo de Fútbol para Padres un escenario apto para continuar investigaciones e indagaciones de aspectos vinculados con el deporte para adultos. Lo que lleva a preguntarme cuántas posibilidades tenemos los adultos de realizar prácticas deportivas, o cuántos adultos podemos realizar prácticas deportivas en las cuáles podamos elegir las variables más importantes para la participación y ejecución de esas prácticas, y no estar sujetos a los intereses del mercado, la actividad que está de moda o lo que la corriente de turno y los medios de comunicación masivos nos marcan como adecuadas. Considero 
sumamente útiles, valiosos y significantes, especialmente para la sociedad adulta actual, la replicación de espacios similares de encuentros deportivos, con cualquier otro tipo de práctica corporal, acorde a los gustos, e intereses y modalidades de los participantes.

Este trabajo también me plantea inquietudes acerca de cuáles son las prácticas más apropiadas para los distintos contextos, edades, poblaciones y creo que sin duda, las más significativas son las que los propios sujetos desean y eligen hacer. Entiendo que estas son las prácticas que hay que analizar, problematizar y descubrir, procurando entender cuáles son los aportes genuinos que desde nuestro rol de profesionales de la Educación Física podemos realizar, intentando poner en valor la elección de esa práctica por parte de los sujetos, sus formas y deseos de cómo llevarla a cabo.

Más allá de propias fronteras de formación, culturales y sociales que ponemos en nuestras miradas, las prácticas deportivas ofrecen una variedad tan grande de matices y lógicas, destrezas y habilidades, formatos y organizaciones, símbolos y representaciones, pero por sobre todas las cosas expresan valores que si se reconocieran con más amplitud y pluralidad pueden contribuir a conformar un orden social más justo para todos. 


\section{BIBLIOGRAFÍA}

ALABARCES, P. (compilador); 2000, "Peligro de Gol" Estudios sobre deporte y sociedad en América Latina, Bs. As., Argentina, CLACSO, ISBN 950-9231-48-7.

ALABARCES, P.; DI GIANO R.; FRYDENBERG J; (compiladores); 1988, "Deporte y Sociedad", Bs. As., Argentina, EUDEBA, ISBN 959-23-0740-2.

ARCHETTI, E., 2003, "Masculinidades. Fútbol, tango y polo en la Argentina”; Bs. As. Argentina, Ed. Antropofagia, ISBN 987-20018-2-0.

, 1984, "Fútbol y ethos", Bs. As. Argentina, FLACSO.

BONINO, L.; 2001, "Masculinidad Hegemónica E Identidad Masculina", España, Centro De Estudios De La Condición Masculina. Universitat Jaume I de Castellón.

BROHM, JM., 1976, "Sociología y política del deporte"; (1ª Parte "Deporte y Sociedad Capitalista Industrial", (pág. 21 a 138). DF México, Ed. Fondo de la Cultura Económica ISBN 2-7443-0034-x.

BOURDIER, P; 1985, "Como se puede ser deportista" en "Sociología y Cultura", DF, México, Ed. Grijalbo.

, 2000, “La dominación masculina”, Barcelona, España, Anagrama

1993, "Estructuras, habitus y prácticas" capítulo III en "El sentido práctico", Madrid, España, Ed. Torres.

1999, “El oficio del sociólogo", Madrid, España, Siglo XXI Editores. 
CANTERO ABAD, Luis: "La construcción de Representaciones Sociales a través del discurso textual” (pág.145).

CARRASCO BELLIDO, Dimas; CARRASCO BELLIDO, David; 2013, “Aprendizaje Motor”; Madrid, España, Instituto Nacional de Educación Física Universidad Politécnica De Madrid.

CEPAL, (Comisión Económica para América Latina y el Caribe), 2000/2002, "Documento de Indicadores de paternidad responsable, México.

D'AGOSTINO, F.; 1981,"The ethos of the games", Journal of the Philosophy of Sport, (p. 7 a 18).

DEVIS DEVIS, J., 2000,"Deporte, Actividad Física y Salud", España, INDE. ISBN 9788495114099

ELIAS, N.; 1987, “La búsqueda de la emoción en el ocio” (p. 83 a 155). El proceso de civilización Investigaciones sociogenéticas y psicogenéticas, DF México, Fondo de la Cultura Económica

ELÍAS, N. y Dunning E.; 1996, "Dinámica de los grupos deportivos con especial referencia al fútbol" y "Dinámica del deporte moderno" (p. 231 a 268) en "Deporte y Ocio en el proceso de civilización”. DF México, Fondo de la Cultura Económica.

ERIKSON E.; 1968, “Identidad, juventud y crisis”, Bs. As. Argentina, Ed. Paidós, 1974.

FAUR, E.; 2004, "Masculinidades Y Desarrollo Social. Las Relaciones de Género desde la perspectiva de los Hombres". Bogotá, Colombia, Arango Editores, Unicef, ISBN 958-270050-5.

GALAK, E.; 2010, "El concepto cuerpo en Pierre Bourdieu. Un análisis de sus usos, de sus límites y de sus potencialidades", Tesis de la Maestría en Educación Corporal Universidad Nacional de La Plata, Bs. As. Argentina. 
2015, "Esbozos de una teoría de la práctica de educar. Pierre Bourdieu, educación de los cuerpos, violencia y capital simbólico", en Revista Tempos e Espaços em Educação (Brasil), Editorial de la Universidade Federal de Sergipe, vol. 8, $\mathrm{n}^{\circ}$ 15, pp. 133-144.

GARCIA FERRANDO, PUIG BARATA Y LAGARDERA OTERO (comps.); 1988, "Sociología del Deporte", Madrid, España, Ed Alianza, ISBN: 84-206-8177-6.

GUTIERREZ SAN MARTÍN, M.; 1995, “Valores sociales y deporte”, La actividad física y el Deporte como transmisores de Valores Sociales y Personales, Madrid, España, Editorial Gymnos, I.S.B.N. 84-8013-042-3.

GUBER, R.; 2005, “El salvaje metropolitano”, Buenos Aires, Argentina, Ed. Paidós.

HERNANDEZ SAMPIERI, R; FERNANDEZ COLLADO, C; BAPTISTA LUCIO, P.; 1998; “Metodología de la Investigación”, DF México, 2a Edición Mac Graw-Hill Interamericana Editores, ISBN 970-10-1899-0.

IRUNDÁIN AGURRUZA, J., 2006, “Goles trascendentales”, (25 a 57), en TORRES C. Y CAMPOS D. (compiladores.) “¿La pelota no dobla?, Ensayos filosóficos en torno al fútbol"; Bs. As., Argentina, Ed. Libros del Zorzal.

KEEN, S.; 1991, "Fuego en el cuerpo. El Varón y lo masculino”. Bs. As. Argentina, Ed. Planeta, ISBN (original en inglés) 0-553-07188-2.

KRETCHMAR, S. R., 1975 "From test to contest: An Analysis of two kinds of counterpoint in sport", (p. 39)

, 2006 "Los Juegos y el Jugar. Especulaciones sobre el valor del fútbol” en TORRES C. Y CAMPOS D. (compiladores), “¿La pelota no dobla?, Ensayos filosóficos en torno al fútbol”; Bs. As., Argentina, Ed. Libros del Zorzal.

JODELET, D. “La reproducción social, fenómenos, conceptos y teoría” en Moscovici S. "Psicología Social II, Pensamiento y Vida Social"; 1984, Barcelona España, Editorial Paidós. ISBN 978-84-7509-343-7 
LACAN, J.; 1999, “Las Formaciones del Inconsciente - Seminario 5"; La Metáfora paterna I; La Metáfora paterna II, Barcelona, España, Ed. Paidós, ISBN 978-950-12-3975-1.

LE BRETON, D.; 2008 "Antropología del cuerpo y la Modernidad"; Cap. 7 -El envejecimiento intolerable, el cuerpo desecho- (pág. 141 a 150), Buenos Aires, Argentina, Ediciones Nueva Visión, ISBN 978-950-602-333-1.

LÜSCHEN G. y WEIS. K.; 1976,"Sociología del Deporte”, Valladolid, España, Editorial Miñón.

MAC INTYRE, A.; 1987, "Tras la virtud”, Barcelona, España, Ed. Crítica. ISBN 97884843217005

MILLÁN María J. R.; 2011, "Los Hombres y la construcción de la Identidad masculina”; Madrid, España, Ed. Visión Libros, ISBN 978-84-9883-935-5.

MORALES J.F.; 2007, "Psicología social" Madrid, España, Editorial Mac Graw HillInteramericana, ISBN 9788448156084

MOREIRA, M. A.; 2012 "Aprendizaje Significativo: Un Concepto Subyacente”, Porto Alegre, RS, Brasil, Instituto de Física, UFRGS Caixa postal 15051, Campus 91501-970.

ORTEGA Y GASSET; 1961, (p.17-18) "The Sportive Origin of the State"; London, England, Norton Library.

OSNAYA ALARCÓN, F., 2004, "Las representaciones sociales como expresiones simbólico-culturales". (133-134).

SANSONE, D.; 1987, "Greek Athletics and the origin of Sports"; (p.37) Berkeley, L.A. U.S.A. University of California Press.

SHIMTZ, K.; 1979, "Sport and Play: Suspension of the ordinary”, (p.68) en TORRES C. Y CAMPOS D. (compiladores), 2006, “¿La pelota no dobla?, Ensayos filosóficos en torno al fútbol"; Bs. As., Argentina, Ed. Libros del Zorzal. 
SERRA MAJEM, L.; ROMAN VIÑAS, B; ARANCETA, J., 2006, "Actividad Física y Salud" Barcelona, España, Elsevier - Masson, ISBN 1084-458-1720-5.

SIMON, R.; "El futbol como fuente de valores morales", $(149,186)$ en TORRES C. Y CAMPOS D. (compiladores) "¿La pelota no dobla?, Ensayos filosóficos en torno al fútbol”; Bs. As., Argentina, Ed. Libros del Zorzal.

SINAY, S.; 2004, "Ser Padres es cosa de Hombres"; Bs. As., Argentina, Ed. Del Nuevo Extremo, ISBN 987-1068-46-8.

SOLÍS, D.; 2002, "Miedos y paradojas, presencias y ausencias en las representaciones del deporte en una escuela de Bella Vista", Buenos Aires, Argentina.

SUITS, B; 2005, "Words on play", (123 a 126), The Grasshopper, games, life and utopia, Peterborough on Broadview Press en TORRES C. Y CAMPOS D. (compiladores), " ¿La pelota no dobla?, Ensayos filosóficos en torno al fútbol"; Bs. As., Argentina, Ed. Libros del Zorzal.

STAKE. R.E.; 1998, "Investigación con estudio de casos", Madrid, España, Ediciones Morata, ISBN 84-7112-422-X.

TÉLLEZ, A. y VERDÚ, Ana D.: 2011, "El Significado De La Masculinidad Para El Análisis Social"; Revista Nuevas Tendencias en Antropología, № 2, Pp. 80-103.

TORRES C. Y CAMPOS D. (compiladores.); 2006, "¿La pelota no dobla?, Ensayos filosóficos en torno al fútbol”, Bs. As. Argentina, Ed. Libros del Zorzal.

TORT, M.; 2008,"Fin del dogma paterno", Buenos Aires, Argentina, Ed. Paidós, ISBN 978950-12-4264-5. 
VIDIELLA J.; HERRAIZ F.; HERNÁNDEZ F; SANCHO, Juana M.; 2011, "Masculinidad hegemónica, deporte y actividad física”, Porto Alegre, Brasil, Movimiento v. 16, n. 04, p. 93-115, octubre / diciembre de 2011.

Artículos recuperados de páginas web:

BARRON ARNICHE, J.; 2010, "El Envejecimiento y el deportista mayor"; Médicos Especialistas Medicina de la Educación y el Deporte, España, http://www.ceefis.com.ar

BUSSEY, T.; Enero 2010, Universidad de Cambridge e Instituto Nacional de los Estados Unidos sobre el envejecimiento. http://www.ceefis.com.ar

CROSS, C.; 2010, "Individuos Divididos y habitus: claves para pensar las representaciones acerca de la actividad física”, Buenos Aires, http:// www.ceefis.com.ar

DUCHI, H.; 2006 "Preguntas y respuestas sobre el envejecimiento". Buenos Aires, http:// www.ceefis.com.ar [consultado en Septiembre 2014]

GIRALDES, M.; 2006, “Acerca del enseñar y aprender”, Buenos Aires, http:// www.ceefis.com.ar

RIOS, S.: Enero 2008, "Quienes hacen Actividad Física envejecen menos". Buenos Aires, http://www.ceefis.com.ar [consultado en Septiembre 2014]

SAAVEDRA, C.; Octubre 1988, "Fitness salud y deporte", Buenos Aires, Año 3, № 11 http://www.efdeportes.com [consultado en Septiembre de 2014]

; Agosto 1999 “Salud, ejercicio físico y nutrición”, Bs. As., Año 4, № 15

http://www.efdeportes.com 
; Abril 2000, "Ejercicio y Salud: A la opinión pública y autoridades gubernamentales de Chile", Bs. As. ; Año 5; № 20; htpp://www.efdeportes.com

http://www.ole.com.ar/fuera-de-juego/nuevoOLEFIL2014605-0001PDF, Jueves 5/6/2014; № 77 pág. 4. Buenos Aires, Argentina. 
ANEXOS 


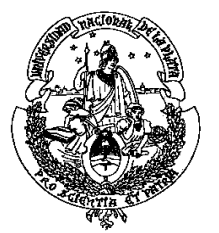

\section{Universidad Nacional de La Plata}

Facultad de Humanidades y Ciencias de la Educación

Secretaría de Posgrado

Maestría en Deporte

\section{O Campito}

TORNEO DE FÚTBOL 11 PARA PADRES DE COLEGIOS DE BELLA VISTA Y SAN MIGUEL

BUENOS DÍAS,

ESTAMOS TRABAJANDO EN UN ESTUDIO QUE SIRVE PARA ELABORAR UNA TESIS PARA EL POSGRADO “MAESTRIA EN DEPORTE” QUE DICTA LA UNIVERSIDAD NACIONAL DE LA PLATA.

QUISIERAMOS PEDIR TU AYUDA PARA QUE CONTESTES ALGUNAS PREGUNTAS QUE NO LLEVARÁN MUCHO DE TU TIEMPO.

TE PEDIMOS QUE CONTESTES ESTE CUESTIONARIO CON LA MAYOR SINCERIDAD, PARA HACER VERDADERAMENTE VALIOSO Y SIGNIFICATIVO EL ESTUDIO.

TUS RESPUESTAS SON CONFIDENCIALES Y ANÓNIMAS Y SU USO PURAMENTE ACADÉMICO.

MUCHAS GRACIAS POR TU COLABORACIÓN

EQUIPO/ COLEGIO:

LOCALIDAD:

EDAD:

OCUPACIÓN:

NIVEL DE ESTUDIOS ALCANZADOS:

PRIMARIO:

SECUNDARIO:

TERCIARIO:

UNIVERSITARIO:

GRUPO FAMILIAR:

CONYUGE:

HIJOS: (CANTIDAD) 
1) ¿DESDE CUÁNDO PARTICIPA DE LOS TORNEOS DE FUTBOL PARA PADRES?

2) ¿CAMBIÓ ALGUNA VEZ DE EQUIPO? SI/NO ¿POR QUÉ?

3) ¿QUÉ LO MOTIVO A PARTICIPAR?

4) ¿POR QUÉ CONTINÚA PARTICIPANDO?

5) ¿CÓMO VALORA EL RESULTADO DE UN PARTIDO? ES LO MAS IMPORTANTE MUY IMPORTANTE $\square$ RELATIVAMENTE IMPORTANTE $\square$ NO ES IMPORTANTE

6) ¿DURANTE LA SEMANA RECUERDA O PIENSA EN EL PARTIDO JUGADO? SI/NO

7) EN CASO AFIRMATIVO: ¿QUÉ COSAS PIENSA O RECUERDA?

8) ¿DURANTE LA SEMANA PIENSA EN EL PRÓXIMO PARTIDO? SI/NO

9) EN CASO AFIRMATIVO: ¿EN QUÉ COSAS PIENSA?

10) ¿REALIZA ENTRENAMIENTOS EN LA SEMANA PARA ESTA COMPETENCIA?

FRECUENCIA: 1 VEZ $\square \quad 2$ VECES $\square \quad 3$ VECES $\square+$ DE 3 VECES $\square \quad$ NUNCA $\square$ DINÁMICA: INDIVIDUAL $\square \quad$ GRUPAL $\square$ TODO EL EQUIPO $\square \quad$ LOS QUE PUEDEN $\square$ 
11) ¿REALIZÓ CONTROLES MÉDICOS EN LAS TEMPORADAS DE LOS TORNEOS?

SI/NO

12) EN CASO AFIRMATIVO: INDIQUE EN QUÉ MOMENTO LO HIZO

ANTES DEL TORNEO

DURANTE EL TORNEO

DESPUÉS DEL TORNEO

13) ¿EN QUE PUESTO JUEGA?

ARQUERO

DEFENSOR LATERAL

DEFENSOR CENTRAL

VOLANTE DEFENSIVO

VOLANTE OFENSIVO

ATACANTE CENTRAL (GOLEADOR)

ATACANTE LATERAL (AYUDA)

14) ¿CAMBIÓ DE PUESTO DESDE QUE COMENZÓ A JUGAR?

SI/NO

15) ¿¿POR QUÉ?

16) ¿CONSIDERA HABER LOGRADO APRENDIZAJES DEPORTIVOS?

a) TÉCNICOS (HABILIDADES MOTORAS ESPECÍFICAS: PATEAR, CABECEAR, QUITES, PASES, DRIBLING, CONTROL)

b) TACTICOS (POSICIONES, ROLES, SISTEMAS DE JUEGO 4-4-2; 4-3-3; 3-4-2-1;)

c) REGLAMENTARIOS (REGLAS DESCONOCIDAS, INTERPRETACIÓN Y USO DE LAS REGLAS) 
17) ¿RECONOCE CAMBIOS EN SU COMPORTAMIENTO SOCIAL (FAMILIA, AMIGOS, TRABAJO, ETC.? QUE PUEDA ASOCIAR A ESTA PRACTICA DEPORTIVA? SI/NO

18) EN CASO AFIRMATIVO: ¿QUÉ CAMBIOS PUEDE IDENTIFICAR?

19) ¿SU FAMILIA APOYA SU PARTICIPACIÓN EN ESTE TIPO DE COMPETENCIAS?

TOTALMENTE $\square$ PARCIALMENTE $\square$ MinimAMENTE $\square$ NO APOYA

20) ¿PODRÍA SUGERIR ALGÚN COMENTARIO CONSTRUCTIVO QUE COLABORE CON LA ORGANIZACIÓN DE LOS TORNEOS?

ESTAMOS MUY AGRADECIDOS POR SU PARTICIPACIÓN Y COLABORACIÓN!

ESPERAMOS SIGA DISFRUTANDO DE LOS TORNEOS DE FUTBOL PARA PADRES. HASTA PRONTO. 
UBICACIÓN DE LOS CAMPOS DE JUEGO (CROQUIS)

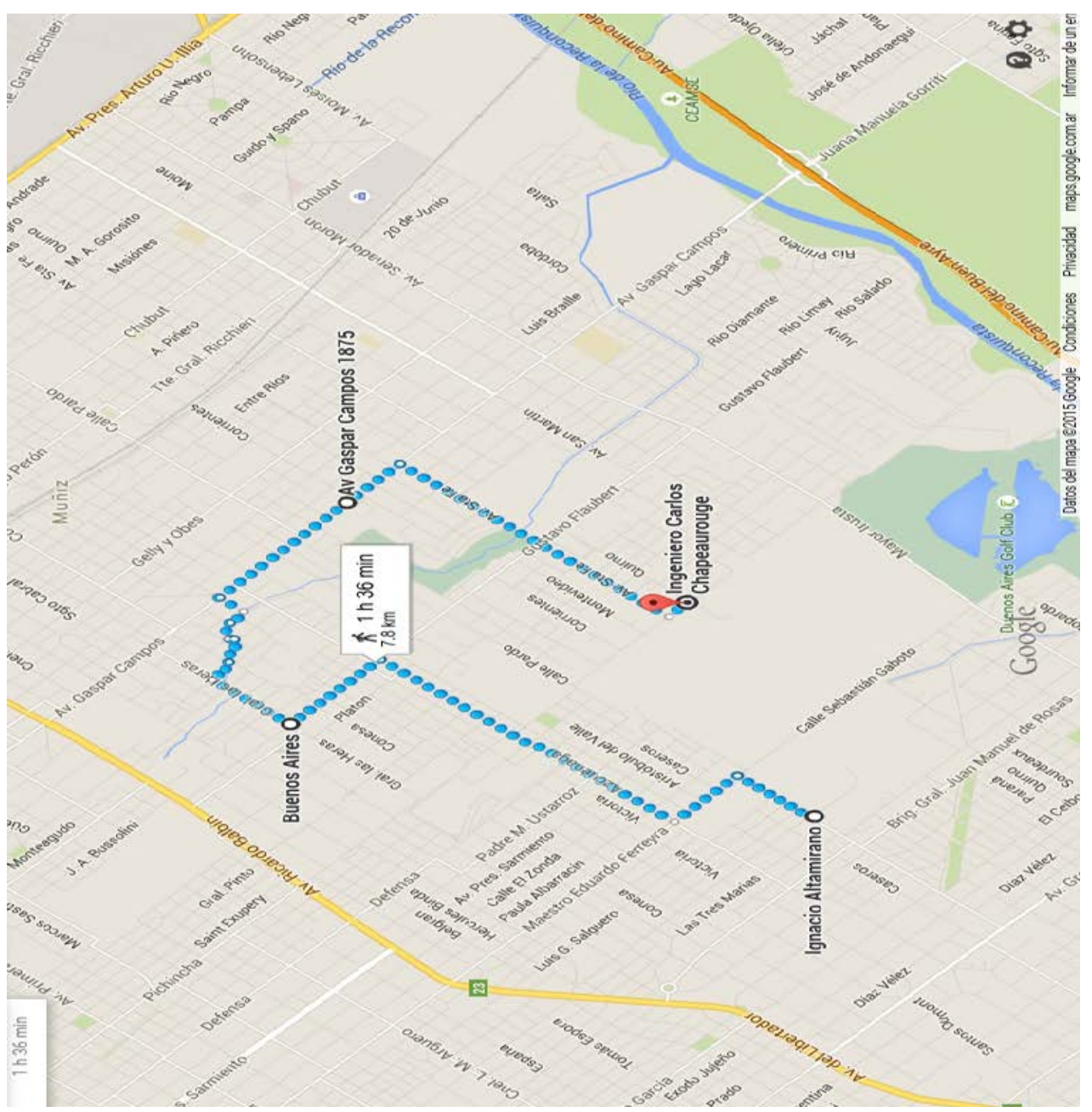

1) Colegio de la Providencia: Ing. Carlos Chapearouge y Quirno, Bella Vista.

2) Residencia de Adultos mayores: Av. Gaspar Campos 1875, Bella Vista.

3) Campo Virgen Niña: Las Heras 2952, San Miguel

4) Club los Indios: Ingeniero Altamirano y Pardo 5220, Bella Vista UBICACIÓN DE LOS CAMPOS DE JUEGO (VISTA SATELITAL) 


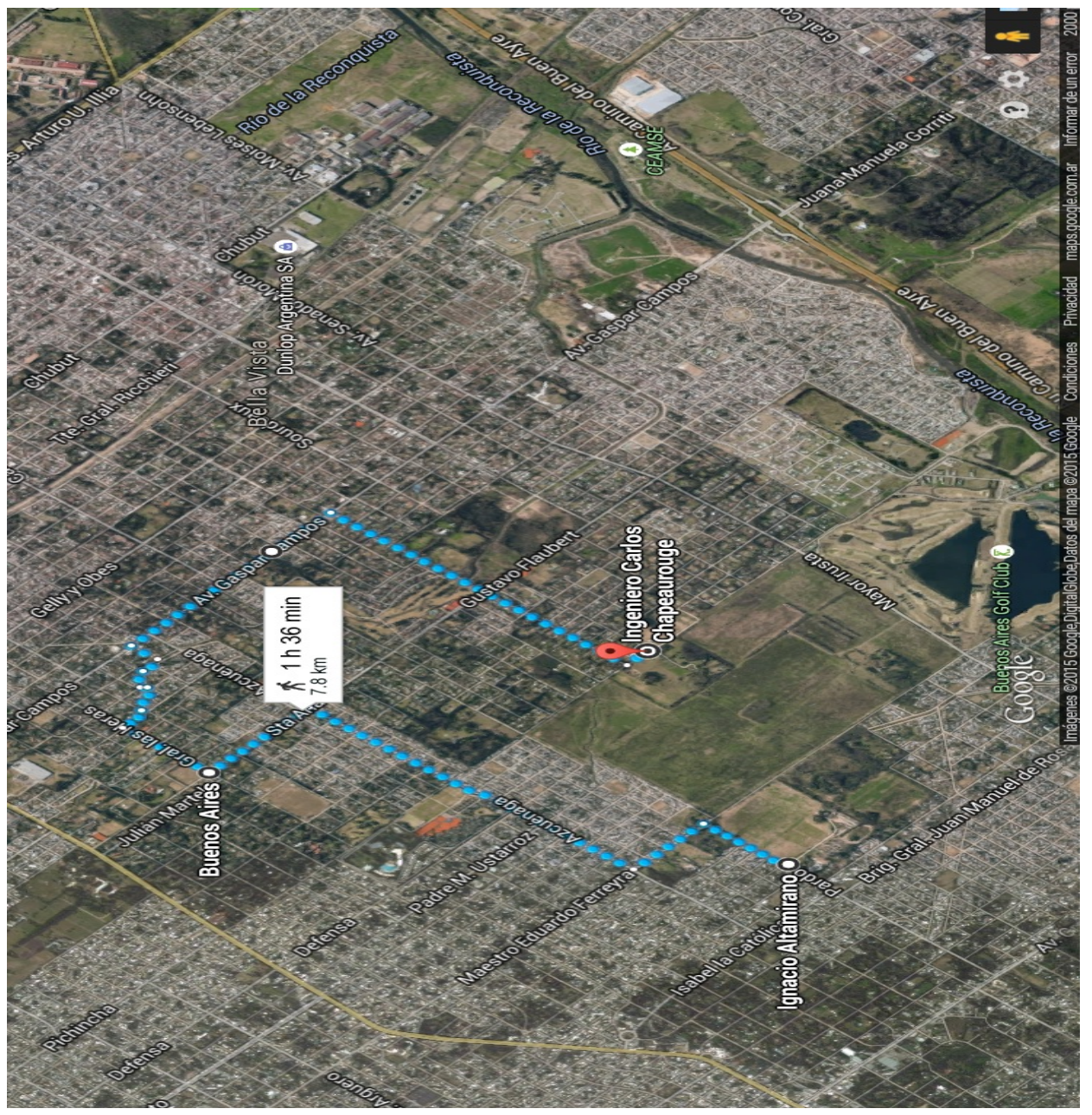

1) Colegio de la Providencia: Ing. Carlos Chapearouge y Quirno, Bella Vista.

2) Residencia de Adultos mayores: Av. Gaspar Campos 1875, Bella Vista.

3) Campo Virgen Niña: Las Heras 2952, San Miguel

4) Club los Indios: Ingeniero Altamirano y Pardo 5220, Bella Vista REGLAMENTO DEL TORNEO

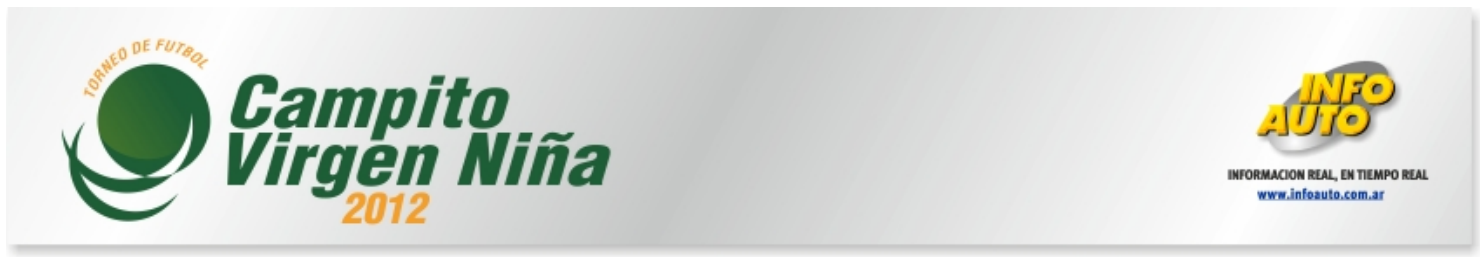




\section{Reglamento}

Fecha: El campeonato comienza el domingo 29 de Marzo de 2015.

Días y Horarios: Los partidos se juegan los días domingo en 6 canchas y en horarios Corridos: $09.00,10.30$ y 12.00 hs.

Inscripción: Cada equipo debe pagar un importe de $\$ 3.000$ en concepto de inscripción por cada uno de los Torneos que dispute.

Forma de Pago: Se abona antes de comenzar cada Torneo

Precio por partido: Al margen de la inscripción, cada equipo debe pagar \$1200 por partido, en concepto de cancha, terna arbitral y servicio médico.

Equipos: Cada equipo debe presentar una lista de buena fe integrada por un mínimo de 15 (quince) jugadores y un máximo ilimitado.

Todos los jugadores deben ser mayores de 32 años o cumplirlos durante el 2014, salvo dos excepciones que podrán tener 30 ó 31 años o cumplirlos durante este año.

Todos los Equipos deben presentar una carpeta foliada y en cada uno de los folios debe contar con: Constancia de alumno regular o recibo de la cuota del colegio indicando el año en que cursa, fotocopia del DNI y responsabilidad civil de cada uno de los integrantes del plantel

El arquero no tiene límite de edad para jugar.

Todos los jugadores deben ser padres de alumnos, de jardín de infantes, primaria

y/o secundaria, EN CURSO en sus respectivos colegios o padres de hijos egresados del 3 año EGB (ex 5to año).

Excepción: podrá formar parte del plantel un padre cuyo hijo/a fue alumno/a de dicha institución en algún momento.

Edad mínima: 32 años

Una vez presentada la lista de buena fe, solo se puede agregar jugadores que no estén anotados en otros equipos.

El jugador anotado en un equipo NO se puede cambiar a otro hasta que se termine alguno de los torneos (Apertura y/o Clausura).

Partidos: Cada equipo debe presentarse a jugar con una camiseta uniforme para cada uno de sus jugadores tanto titulares como suplentes, las mismas deberán tener impreso el número correspondiente.

Se jugará con el reglamento de AFA, aplicándose la ley del Off-Side.

Todos los partidos son dirigidos por un referee y dos linesmans oficiales.

El tiempo de juego es de 80 minutos dividido en dos periodos de 40 cada uno, con un descanso de 10 minutos. 
Cada equipo debe entrar a la cancha con un máximo de once jugadores (10 más el arquero).

Al equipo que no se presente a jugar se le da por perdido el partido por 3-0.

Debe pagar los pesos correspondientes del partido suspendido y los pesos correspondientes a los rivales (quedando estos excluidos de dicho pago)

El tiempo de tolerancia:

Cada equipo tiene una tolerancia máxima de 10 minutos, transcurrido ese tiempo, el árbitro iniciará el encuentro con la cantidad de jugadores que haya en ese momento, pudiendo ingresar los protagonistas faltantes con posterioridad teniendo que cumplir con el punto anterior. En caso que los 2 equipos no se presenten, ambos equipos pierden 3 (tres) puntos y deben pagar los pesos del partido como si lo hubiesen jugado.

Planilla

Cada capitán, antes de empezar, se tiene que acercar a la mesa de control, al costado de la cancha donde juega, a completar la planilla, entregar los carnet de los jugadores que van a disputar ese encuentro y a pagar el partido al veedor de la cancha.

Los árbitros confeccionan una planilla con todas las incidencias de los partidos.

Dicha planilla debe será firmada por el capitán de cada equipo, referee y por el veedor.

Una vez firmada la planilla no se aceptará cambios en la misma

Para lo cual se le solicita a cada capitán que controle bien lo que firma.

No firmar la planilla equivale a conformidad de la misma por parte del capitán

Cambios de jugadores durante el partido

La cantidad de cambios de un equipo durante el desarrollo del partido es de 6 (seis), en el entre tiempo los cambios son ilimitados, jugador que sale puede volver a ingresar.

II Suspensión de partidos

Todos los partidos suspendidos por cualquier motivo pasan a jugarse el día que lo dispongan los organizadores.

En caso de suspenderse una fecha en su totalidad, la misma pasa a jugarse EL FIN DE SEMANA SIGUIENTE.

En caso de que algún colegio tenga alguna actividad a nivel institucional (comunión, día de la familia, confirmación, etc.) que afecte seriamente la convocatoria en algún partido, el capitán debe avisar a los organizadores el lunes anterior a dicho partido a través de un mail, con el objetivo de poder reacomodar los horarios de la fecha.

Si la suspensión del partido es porque uno de los equipo quedo con menos de 8 jugadores por expulsiones, dicho partido, se le da por ganado al equipo contrario por 3 a 0

Campeonatos: 
Los campeones de torneos Apertura Y Clausura de la ZONA "A" se enfrentarán en una "GRAN FINAL"

El ganador de esta final será: "EL CAMPEÓN DE LA COPA VIRGEN NIÑA 2014"

Ascensos y Descensos

Ascensos: El campeón y el Subcampeón del Torneo Apertura de la "B", jugará el Torneo Clausura en la categoría inmediata superior durante el año 2014, mientras que el campeón y el subcampeón del torneo Clausura lo hará a partir del Apertura 2015.

Descensos: Descenderá a la categoría inmediata inferior los equipos que ocupen los 2 últimos lugares en el Apertura o Clausura.

El equipo descendido en el Torneo Apertura 2014, jugará el Torneo Clausura 2014, en la categoría inmediata inferior, mientras que el descienda en el Clausura 2014, lo hará en el siguiente año

Desempate:

En caso de igualdad de puntos se desempatará de la siguiente manera:

1. Mejor ubicación en la Tabla Fair Play.

2. Mejor diferencia de gol.

3. Más goles a favor.

4. Menos goles en contra.

5. Resultado entre los equipos igualados.

Tribunal de disciplina:

Funciones: Evaluar las incidencias de los partidos del campeonato, tanto de los jugadores como de los equipos, referee y público.

El tribunal sancionará solamente en base al informe del referee, el informe del veedor y de lo que cada miembro pueda apreciar de las incidencias de los partidos

VELARA POR EL CUMPLIMIENTO DEL ESPIRITU DEL CAMPEONATO QUE SERA DE

DIVERSION, DE BUEN COMPORTAMIENTO, DE EJEMPLO PARA LOS CHICOS, DE

RESPETO A LOS COMPAÑEROS, CONTRARIOS Y REFEREES Y DEL BUEN GUSTO

EN LAS ACTITUDES Y EL LENGUAJE.

Sanciones disciplinarias:

Amonestaciones

CADA TRES AMARILLAS APLICADAS A UN MISMO JUGADOR, ESTE DEBERA CUMPLIR UNA FE CHA DE SUSPENSION 
Expulsiones

CADA VEZ QUE UN JUGADOR RECIBE UNA TARJETA ROJA DEBERA CUMPLIR COMO MÍNIMO 1 FECHA DE SUSPENSION.

En todos los casos de expulsión la sanción puede ser ampliada a más fechas según su gravedad, siendo esto decisión del Tribunal de Disciplina.

Roja directa Todas las rojas directas son sancionadas como MINIMO con 2 fechas salvo las sanciones leves de último recurso, en este caso el Tribunal decidirá la sanción que deba imponerse

Sin-Bin:

- Esta sanción es aplicable a los excesos verbales.

- El sancionado con esta pena permanecerá 10 minutos fuera de la cancha (sin poder ingresar un reemplazo).

- Al jugador que le corresponda (a criterio del referee) un segundo Sin-Bin durante el mismo partido será expulsado y la sanción será como MINIMO DE 2 FECHAS

- El Sin-Bin se puede aplicar solo o acompañado de una amarilla.

- El referee puede prescindir del Sin-Bin y ante una falta verbal grave puede aplicar directamente la expulsión. La sanción será como MINIMO DE 2 FECHAS.

CADA TRES SIN-BIN QUE RECIBA UN MISMO JUGADOR DEBERA CUMPLIR UNA

FECHA DE SUSPENSIÓN

EQUIPO QUE INCLUYA UN JUGADOR INDEBIDAMENTE SERA SANCIONADO COMO MINIMO CON 6 FECHAS DE SUSPENSION PARA SU CAPITAN Y LA QUITA DE TODOS LOS PUNTOS ACUMULADOS HASTA ESE MOMENTO. EL JUGADOR MAL INCLUIDO SERA EXPULSADO POR EL RESTO DEL AÑO.

DE REINCIDIR EN LA MISMA FALTA QUEDARÁ FUERA DE TODOS LOS TORNEOS ORGANIZADOS POR VIRGEN NIÑA DURANTE 2013.

SU NUEVA INCLUSIÓN DURANTE EL AÑO 2014, SERÁ EVALUADA POR LA ORGANIZACIÓN, DEBIENDO ABONAR PREVIAMENTE LAS INSCRIPCIONES QUE NO HUBIERAN ABONADO DURANTE 2013 (AUNQUE NO HUBIESE DISPUTADO ALGUNO DE LOS TORNEOS POR HABER SIDO SANCIONADO PREVIAMENTE), COMO ASÍ TAMBIÉN EL IMPORTE DE CADA UNO DE LOS PARTIDOS QUE NO SE PUDIERON JUGAR POR SU RESPONSABILIDAD.

EL PARTIDO EN EL SE PRODUJO ESTA FALTA SE LO DARÁ POR PERDIDO (0-3) Y AL EQUIPO CONTRARIO SE LE DESCONTARÁN 5 PUNTOS EN EL FAIR PLAY, QUEDANDO SIN EFECTO LAS TARJETAS QUE HAYA TENIDO EN EL DESARROLLO DEL PARTIDO 
Acumulación de Tarjetas

Son acumulativas a lo largo de todo el campeonato tanto para el jugador como para el equipo.

Tabla Fair Play:

En la tabla fair play se contabilizan las tarjetas que se le aplican a cada equipo.

- La tarjeta amarilla equivale a 1 punto.

- La tarjeta azul (Sin-Bin) a 2 puntos.

- La roja equivale a 4 puntos.

- Cada partido que un equipo no se le aplican tarjetas SE descuenta 5 puntos.

EL EQUIPO QUE SUME 40 PUNTOS EN LA TABLA DE FAIR PLAY SE LE DESCONTARAN EN ESE MOMENTO, 3 PUNTOS EN LA TABLA DE POSICIONES, A PARTIR DE ESE NUMERO SE LE DESCONTARAN 3 PUNTOS MAS POR CADA 10 PUNTOS QUE AGREGUE E N LA TABLA.

- 40 Puntos que sume en tabla Fair Play se le descuentan por total 3 puntos en la tabla de posiciones.

- 50 puntos que sume en tabla Fair Play se le descuentan por total 6 puntos en la tabla de posiciones.

- 60 puntos que sume en tabla Fair Play se le descuentan por total 9 puntos en la tabla de posiciones

EL EQUIPO CON MENOS PUNTOS EN LA TABLA DE FAIR PLAY SERA EL EQUIPO FAIR PLAY DEL AÑO.

Premios en juegos

Campeón de la COPA VIRGEN NIÑA

Sub Campeón de la COPA VIRGEN NIÑA

Tercero: de la COPA VIRGEN NIÑA

Goleador del Apertura y Clausura de cada una de las categorías

Arquero menos vencido del Apertura y Clausura de cada una de las categorías

Mejor jugador del año.

Mejor jugador de cada equipo (elegido por sus compañeros)

Mejor compañero de cada equipo (elegido por sus compañeros) 
Equipo Fair Play de año

Equipo ideal del año

Mejor jugador de cada partido

LOS ORGANIZADORES DE LA COPA VIRGEN NIÑA SE RESERVAN EL DERECHO DE ADMISION Y PERMANENCIA. 